تنمية مهارات تصيميم القصة الرقمية باستخدام الكتاب الإلكتروني وعلاقتها بمستوي طموح معلمي

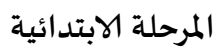

تنمية مهارات تصميم القصة الرقمية باستخدام الكتاب الإكتروني وعلاقتها بمستوي طموح معلمي المرحلة الابتدائية

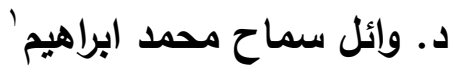

مستخلص: هدفت الدراسة إلى تتمية مهارات تصميم القصة الرقمية باستخدام الكتاب

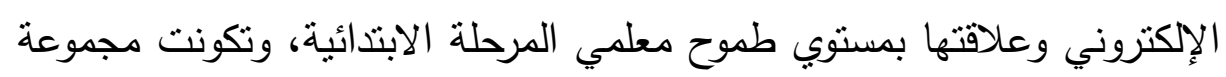

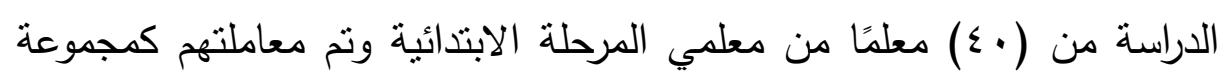

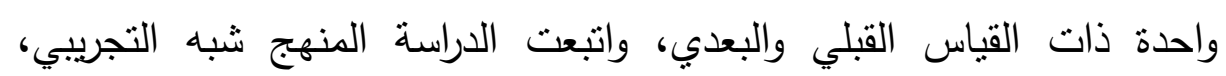
وتكونت أدوات الدراسة من قائمة مهارات تصميم القصة الرقمية، واختبار تحصيلي لقياس الجانب المعرفي لمهارات تصميم القصة الرقمية، وبطاقة تقييم مهارة، وأظهرت النتائج وجود فرق دال إحصائيًا بين درجتي القياس القبلي والبعدي لصالح القياس البعدي في كل من الاختبار التحصيلي وبطاقة تقيبم مهارة، وهذا يدل على فاعلية الكتاب الإكتروني في تتمية مهارات تصميم القصة فئ

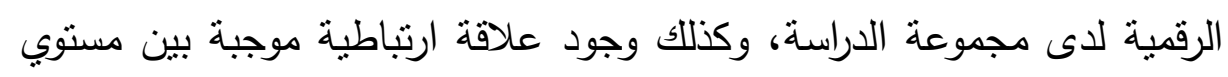
الطموح ومهارات تصميم القصة الرقمية. الكلمات المفتاحية: الكتاب الإكتروني، القصة الرقمية، مستوي الطموح. ' مدرس تكنولوجيا التعليم ـ كلية التربية النوعية بقتا ـ جامعة جنوب الوادي. 
تنمية مهارات تصميم القصية الرقمية باستخدام الكتاب الإلكتروني وعلاقتها بمستوي طموح معلمي المرحلة الابتدائية

\section{Developing the Skills of Designing Digital Story by Using $E$ Book and Its Relation to the Level of Aspiration of Primary School Teachers}

\section{Abstract:}

The study aimed to the skills of designing digital story and its relation to the level of aspiration of primary school teachers. The study group consisted of (40) teachers of the primary stage and they were treated as one group with tribal and remote measurement, The results showed that there was a statistically significant difference between the pre-and post-measurement criteria in favor of the post-measurement in both the achievement test and the evaluate skill card. This indicates the effectiveness of the electronic book in the achievement of the skills of designing the digital story in the study group, as well as the existence of a positive correlation between the level of aspiration and skills of designing digital story.

Keywords: E book, digital story, aspiration level. 
تنمية مهارات تصيميم القصة الرقمية باستخدام الكتاب الإلكتروني وعلاقتها بمستوي طموح معلمي

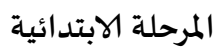

\section{مقدمة}

يشهد العصر الراهن شكلا جديدا من أشكال التجلي الرمزي بسبب رواج

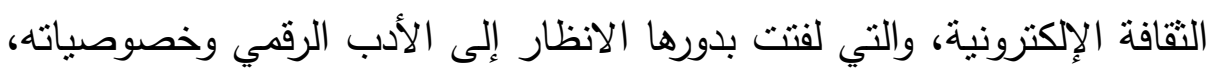
وساهمت الوسائط الإلكترونية في تطوير النص الأدبي وأجناسه الأدبية كالقصة، ولابه وذلك بإخضاعها لتقنيات التكنولوجيا الحديثة، وعرفت القصة تطورا كبيرا في العصر الرقمي، وذلك بمواكبتها لمستجدات الوسائط المتفاعلة، وتحولت في كثير من الاحيان من قصة ورقية الى قصة رقمية.

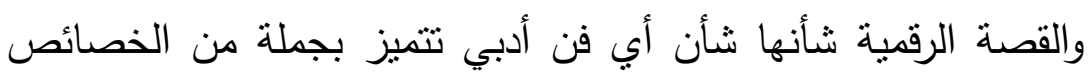

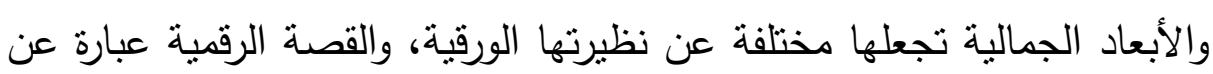
قصة واقعية أو خيالية مكتوبة بأحد برامج تصميم القصص الرقمية التي تستخدم

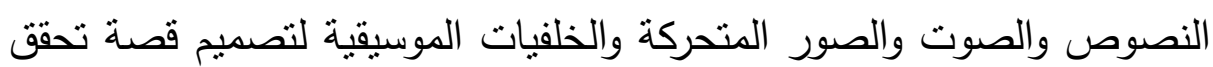
الهدف الذي أُنشأت من أجله.

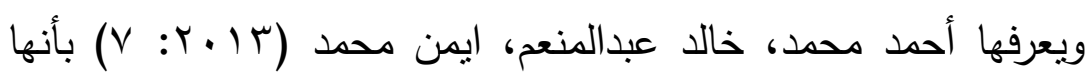
مجموعة المواقف التعليمية للقصة التقليدية التي يتم تحويلها باستخدام برامج الحاسب الالي لتحاكي الواقع بالصوت والصورة وتصميم الصور بها بالأبعاد بله باديه الثنائية والثلاثية.

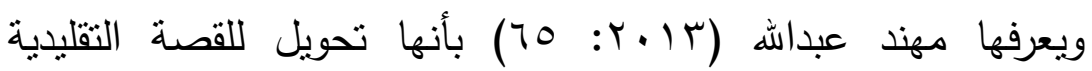
المجردة إلى قصة تعمل من خلال وسيط الكتروني يتم تعزيزه بتكنولوجيا التعلم الإلكتروني والوسائط المتعددة مع ضرورة الاستفادة من تكنولوجيا التعلم

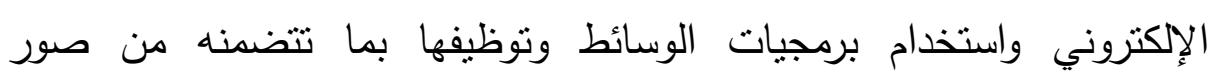
ونصوص وسرد مسجل ومؤثرات صوتية.

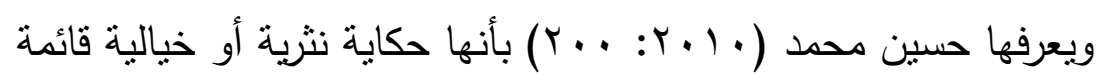
علي استخدام برمجية فوتو ستوري في المزج المنظم للصور والخرائط والنصوص 
تنمية مهارات تصيميم القصة الرقمية باستخدام الكتاب الإلكتروني وعلاقتها بمستوي طموح معلمي المرحلة الابتدائية

والخلفيات الموسيقية والتعليق الصوتي بغرض تجسيد الأحداث والثخصيات والمواقف والظاهرات التي تدعم تحقيق هدف أو اكثر من أهداف تعليم وتعلم الجغرافيا.

ويتضح من تلك التعريفات أنها تتضمن جميعها نص مكتوب مع وسائط

مختلفة من وسائط البرامج الإلكترونية لتصميم قصة رقمية.

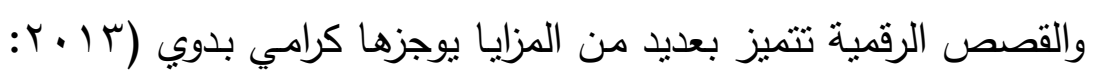

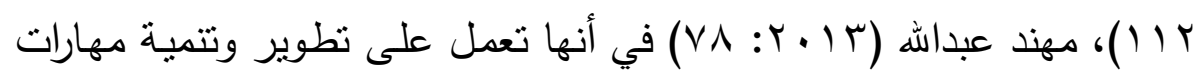

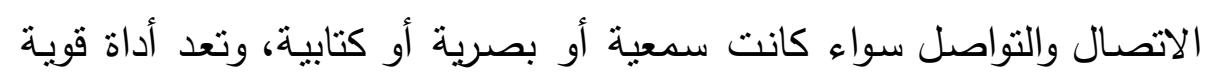

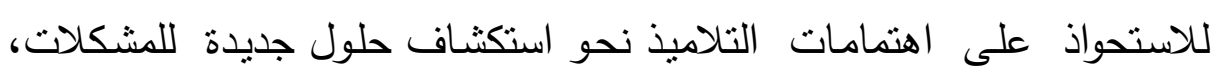
وتعمل على تتمية بعض مهارات التقكير الإبداعي وبالأخص مهارة الطلاقة والمرونـة، وتساعد على تتميـة التأمل والاستبطان والاكتشـاف وهذا يعطي بعدا

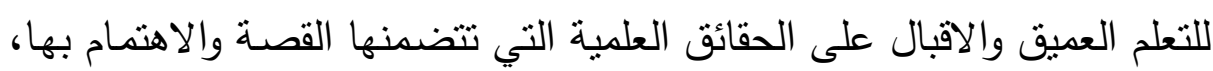
وتزوده بمعلومات ثقافية منتقاه، وتكسبه معارف متقدمة في مرحلة مبكرة، وتقدم

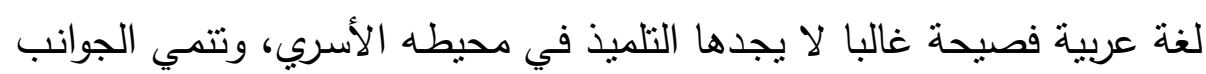
الاجتماعية والنفسية والانفعالية لديه، وتعزز مفهوم التعلم مدى الحياة والتعلم الذاتي.

والقصة الرقمية لها مواصفات يجب أن تتصف بها تحددها هديل محمد

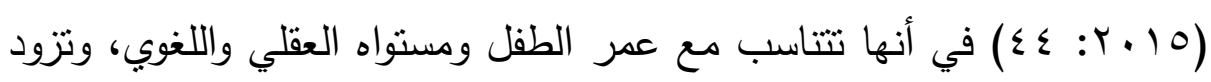
الأطفال بالخبرات والمعارف الجديدة، وتتتهي نهاية سعيدة ومبهجة، وأن تكون سهلة التشغيل والاستخدام من قبل الطفل. وهناك أنواع من القصص الرقمية ينبغي أن تقدم للطلاب في مراحل

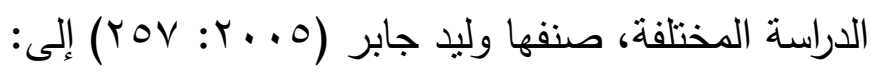
قصص الأخلاق والمتل العليا: تُربي الطلاب على حب الناس واحترامهح ومساعدتهم والتضحية في سبيلهم، وتحببهم بالحق ونصرته.

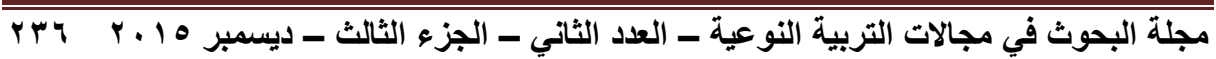


تنمية مهارات تصيميم القصة الرقمية باستخدام الكتاب الإلكتروني وعلاقتها بمستوي طموح معلمي المرحلة الابتدائية

قصص اجتماعية: تهدف إلى تصوير أنماط مختلفة من حياة الثرائح الاجتماعية التي تعيش في مجتمع الطالب، بقصد تعرف الطرائق المختلفة للتعامل مع المجتمع.

قصص ناريخية: يقدم فيها سير الرموز البشرية المشهورة في الأمة، التي منتلت

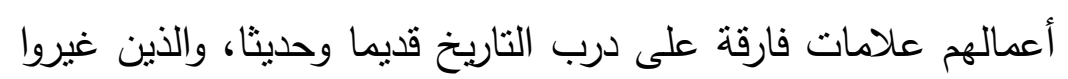

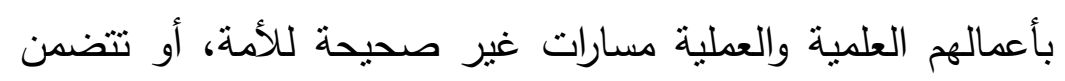

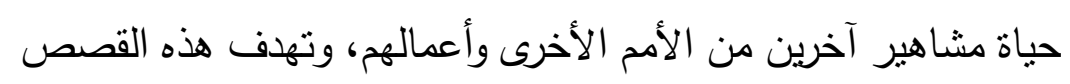

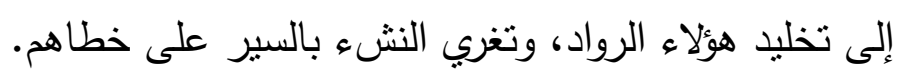

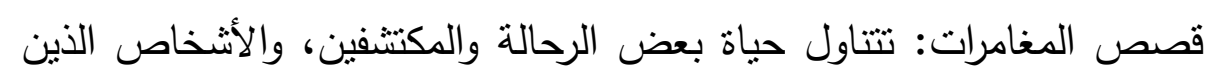
يساعدون في كثف الجرائم وتعقب المجرمين الخارجين على قيم المجتمع، ومثل هذه القصص تتمي حب الاسنطلاع عند الطلاب،

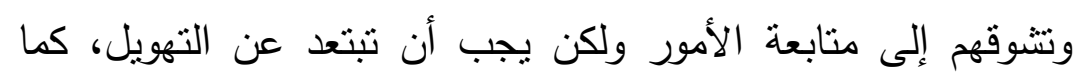
يجب ألا تقدم فيها الأمور مبسطة إلى درجة يبدو قيام الأطفال بها

\section{ممكنا.}

قصص فكاهية: تهدف إلى تقديم المتعة للطالب، والى تجديد نشاطه ومساعدته في أن بضفي علي حياته مع زملائه وأسرته لونا من المرح والدعابة تهنية

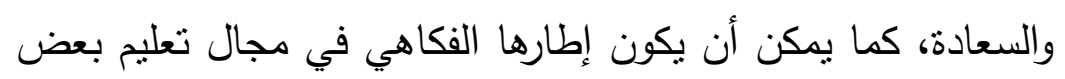

$$
\text { مفردات المادة الدراسية. }
$$

قصص رمزية: تهدف إلى تقديم العظة والعبرة، والتوجه إلى السلوك الحميد

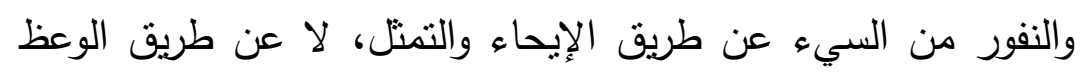

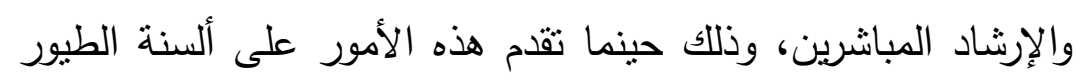

$$
\text { أو السلاحف أو غيرها. }
$$

والقصص الرقمية إذا أُحسن استخدامها من خلال إجادة مهارات تصميمها فإنها تفيد في عملية التعليم والتعلم بالنسبة لكثير من المفاهيم 
تنمية مهارات تصيميم القصة الرقمية باستخدام الكتاب الإلكتروني وعلاقتها بمستوي طموح معلمي المرحلة الابتدائية

والمهارات المختلفة للطلاب، فتوضح دراسة منى رأفت (10 • ب) فاعلية القصص الرقمية التفاعلية في تحسن مستوى التذكر والفهم والتطبيق بالنسبة للمفاهيم الجغرافية لاى تلاميذ الصف الرابع الابتدائي، وتوضح دراسة محمد حمدي

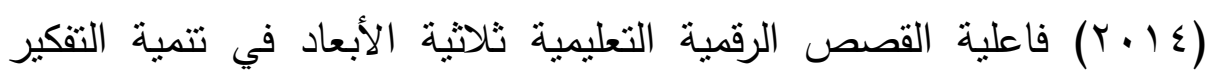

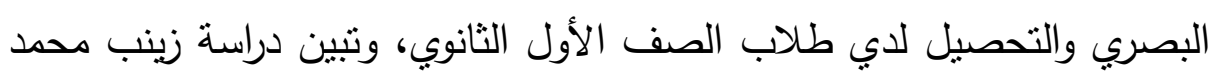

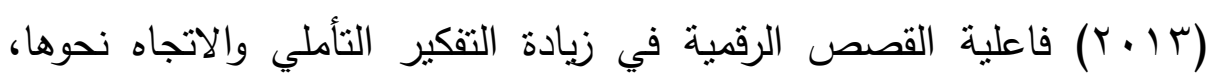
وتوضح دراسة نادر سعيد (9 . . ب) بأن هناك تطور واضح في معارف الطلاب

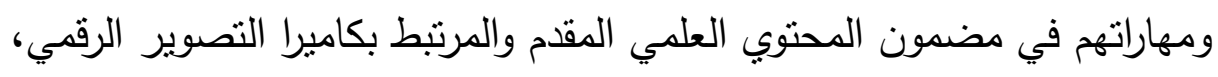

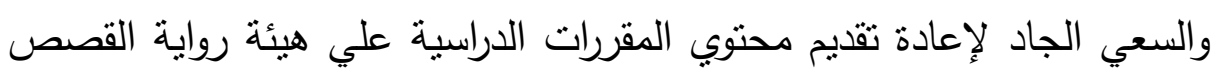
الرقمية كلما كان طبيعة المحتوي يسمح بذلك. وفي ظل الثورة الرقمية التي يشهدها العالم، تحول الكتاب من شكله

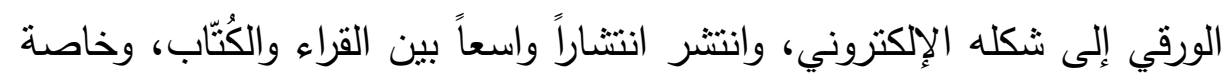
مع ابتكار شاشات لهذه الكتب تُضاهي الصفحات الورقية للكتب التقليدية،

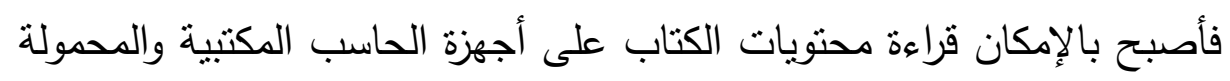

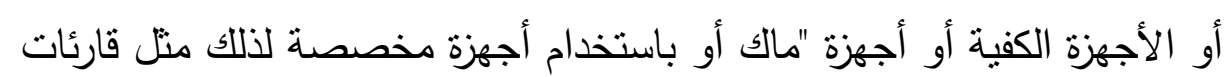
الكتب الإلكترونية.

والكتاب الإلكتروني عبارة عن وسيط معلوماتي رقمي يتم إنتاجه عن

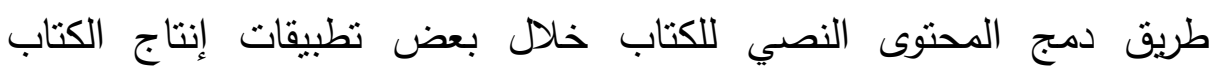
الإككتروني علي الحاسبات، لإنتاج الكتاب في شكل إلكتروني يكسبه المزبد من

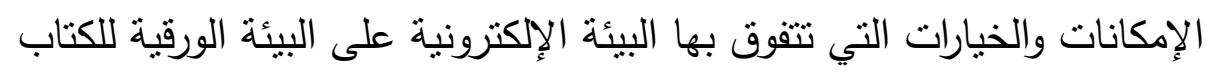
كاسترجاع النص والنشر الثبكي وإضافة الروابط والوسائط المتعددة إلى غير ذلك.

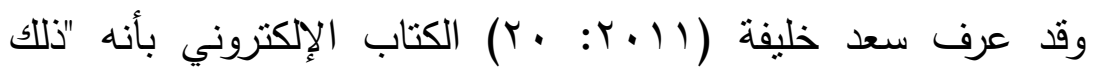
الكتاب الموجود ببعض المواقع الإكترونية، والذي يضم عدداً من الموضوعات 
تنمية مهارات تصيميم القصة الرقمية باستخدام الكتاب الإلكتروني وعلاقتها بمستوي طموح معلمي المرحلة الابتدائية

التعليمية، التي تتضمن بجانب النص، الصور الملونة والصوت والحركة، والمؤثرات الضوئية، وغيرها من عناصر التشويق التعليمي، مما يميز هذا النوع من الكتب عن الكتاب الورقي المطبوع".

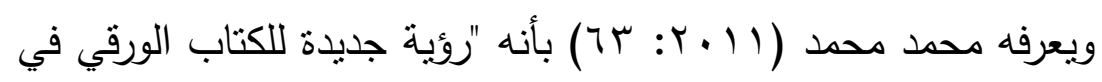

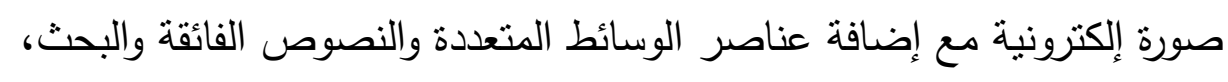
وهو بهذا يجمع بين سمات الكتاب الورقي المطبوع وسمات الوسائط المتعددة،

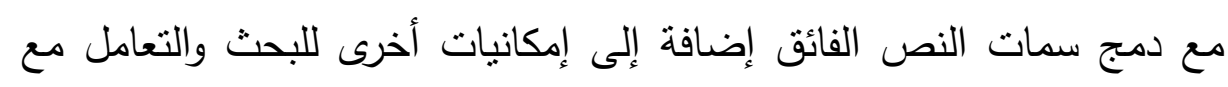

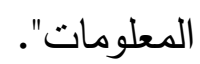

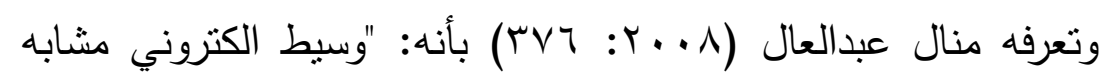
للكتاب التقليدي ويحتوي على مادة علمية تعليمية نصية ومدعمة بوسائط متعددة أخرى، ويمكن نشره على الإنترنت أو تخزينه على اسطوانات مدمجة."

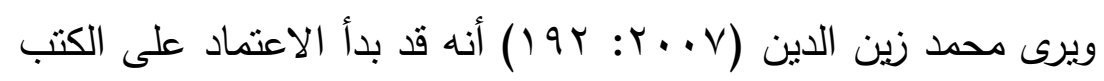
الإكترونية، بعد تحقيقها لنتائج جيدة على المستوى العالمي، وظهور أثرها

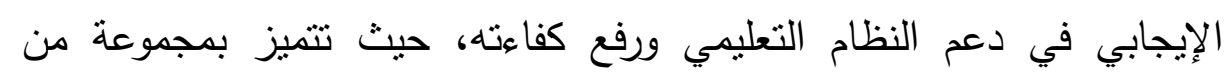
الخصائص الهامة حددها في ما يلي: وجود وسائط متعددة من نصوص وصوم ورسوم وصوت وأفلام متحركة، ولديه نسبة عالية من التفاعلية مع القارئ، مريح

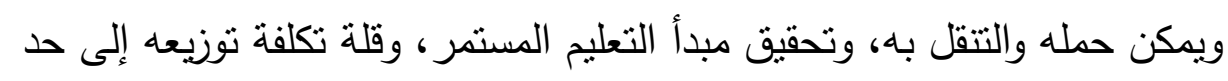
كبير، والقدرة على التحكم في شكل العرض مع خصائص رقمية لتدوين الملاحظات والبحث والتحول إلى نص مقروء. وواجهة تفاعل المستخدم تعد من أهم أجزاء البرنامج ويحتاج تصميمها للكثير من الوقت حتى تكون النتيجة جيد وذللك لأنها حلقة الوصل بين المستخدم والوظيفة المرجوة من البرنامج، ولأن هذه الواجهة سوف يتعامل معها المستخدم كل الوقت فيجب على المصمم تصميم واجهة تفاعل تتاسب طبيعة المستخدم

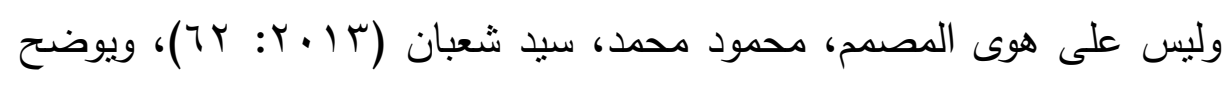

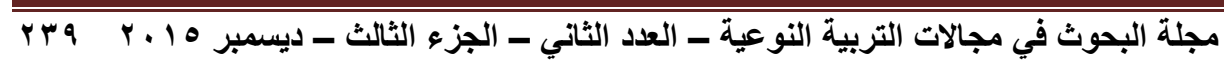


تنمية مهارات تصيميم القصة الرقمية باستخدام الكتاب الإلكتروني وعلاقتها بمستوي طموح معلمي المرحلة الابتدائية

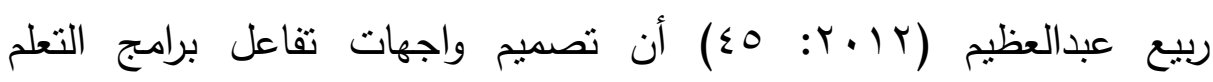
الإلكتروني القائم على الويب ليست مجرد صف لعناصر التحكم فوق النماذج

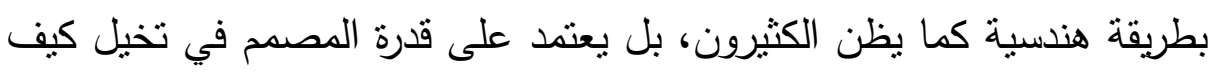
سيبدو شكل المنتج النهائي، وما هي الواجهات الأنسب التي سنزود المستخدم بها للتحكم ببرنامجنا، ثم بعد ذلك تأتي مرحلة نرتيب هذه الواجهات الأكفأ، وفي

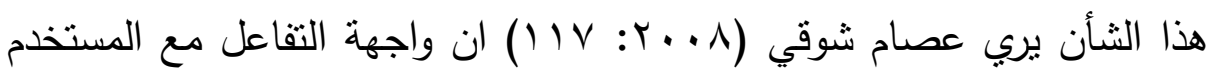

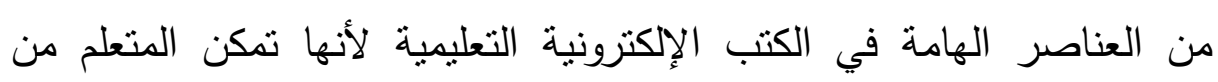
التفاعل مع الكتاب الإكتروني بما تحتويه من ازرار وايقونات ورسومات دالة وتصميم الصفحات، وتتظيم القوائم، وهي تسمح للمتعلم من التجول والابحار بين صفحات الكتاب وتتقسم واجهة التفاعل او الاستقبال الى شقين شق منطقي وشق وشن ونق آخر محسوس حيث يتعلق الثق المحسوس بكل ما يرى اثتاء التفاعل مع الكتاب الإكتروني ويؤثز التصميم البصري لصفحة الاستقبال (واجهة التفاعل) على انطباع المستخدم ومدى فهمه له، ورغبته في استخدامه ويشمل التصميم

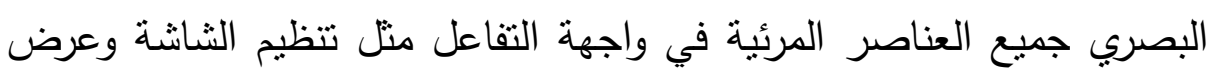
المعلومات وتقديم المساعدات المرئية. وتظهر أهمية الكتاب الإكتروني من خلال مميزاته المتعددة مثل سهولة النقل والتحميل علي اجهزة منتوعة، وسهولة الوصول الي محتوياته عشوائيا باستخدام الحاسوب، واحتوائه علي وسائط متعددة مثل الرسوم المتحركة والصور، وسهولة الاستخدام عن طريق الحاسوب وسهولة الرجوع الي المراجع العلمية التي تؤخذ منها الاقتباسات باستعمال الروابط وامكانية التلوين والتعليق اثثاء عرض الكتابة وسهولة عرضه علي الطلاب في قاعات الدراسة باستخدام وحدة عرض البيانات LCD او جهاز البروجكتور المتصل بالحاسوب وسهولة

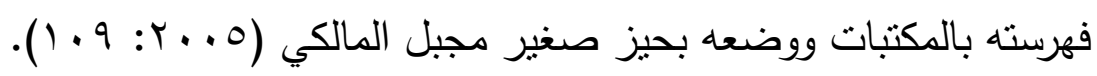
لذا بمكن القول بأن الكتاب الإكتروني يتميز عن الكتاب الورقي بأنه

مجلة البحوث في مجالات التربية النوعية ـ العدد الثاني ـ الجزء الثالث - ديسمبر 10 
تنمية مهارات تصيميم القصة الرقمية باستخدام الكتاب الإلكتروني وعلاقتها بمستوي طموح معلمي المرحلة الابتدائية

رخيص بالمقارنة مع الكُتب الورقية، وسهولة البحث والنقل والنسخ من خلاله،

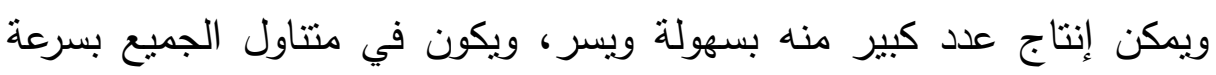
فائقة حول، ويمكن شراءه من أي مكان في العالم بسهولة.

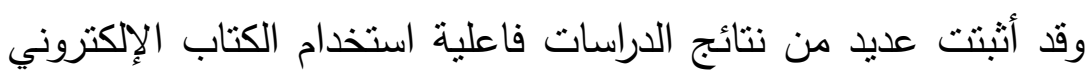
في تتمية كثير من المهارات المختلفة لدي الطلاب، فقد هدفت دراسة مها ابراهيم

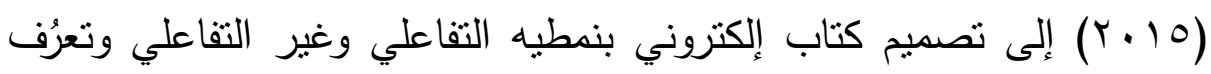
أثره في تتمية الجوانب المعرفية والعملية لدى تلاميذ الصف الأول الإعدادي من ذوى صعوبات التعلم في مادة الحاسوب، وتوصلت النتائج إلى وجود فروق في الجوانب المعرفية والأداء العملي للتنلاميذ من ذوى صعوبات التعلم بعد استخدام الكتاب الإلكتروني بنمطيه التفاعلي وغير التفاعلي. وهدفت دراسة مخلا حمزة (ع ا ـ Y) الي تقديم أحد أشكال تصميم الكتاب الإلكتروني، والذى يمكن من خلاله تقديم مقرر الجغرافيا لدى طلاب المرحلة الثانوية بما في ذلك من أدوات مختلفة للتحكم في العرض والتجوال داخل الكتاب الإكتروني، وكذللك معرفة اثرة علي كفاءة تعلم الجغرافيا لدى طلاب المرحلة الثانوية، وتوصلت النتائج الي وجود فرق دال إحصائًاً عند مسنوى (0 . . .) بين متوسطي درجات المجموعة الضابطة والمجموعة التجريبية في التحصيل المعرفي وكفاءة تعلم الجغرافيا والاتجاه نحو الكتاب الإلكتروني لصالح المجموعة التجربيية في مادة الجغرافيا.

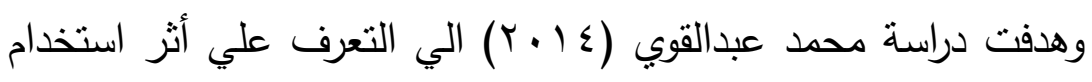

كتاب إلكتروني قائم علي حل المشكلات في تدريس العلوم علي تتمية بعض مهارات التفكير لدي تلاميذ المرحلة الإعدادية وتوصلت النتائج عن وجود فروق داب ذات دلالة احصائية بين متوسطات درجات طلاب المجموعة التجريبية في التطبيق البعدي للاختبار المعرفي ككل وبالنسبة لكل مستوي من المستويات المعرفية الفرعية و مهارات التفكير ككل لصالح المجموعة التجريبية.

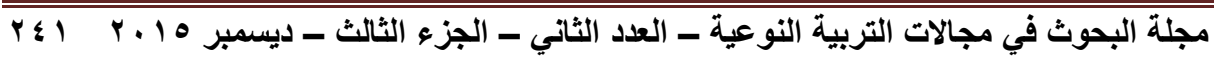


تنمية مهارات تصيميم القصة الرقمية باستخدام الكتاب الإلكتروني وعلاقتها بمستوي طموح معلمي المرحلة الابتدائية

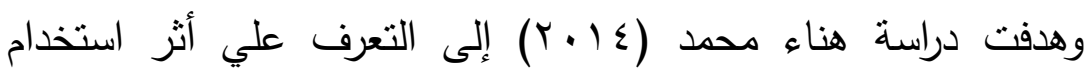
الكتاب الإككترني على التحصيل الدراسي وتتمبة بعض مهارات عمليات العلم الأساسية في مادة الكمبيوتز وتكنولوجيا المعلومات لدى تلاميذ المرحلة الإعدادية، وتوصلت النتائج إلى وجود فروق ذات دلالة إحصائية بين متوسطي درجات تلامبذ المجموعة الضابطة والتجريبية في التطبيق البعدي للاختبار التحصيلي و مهارات عمليات العلم الأساسية لصالح المجموعة التجريبية. وهدفت دراسة سمية رباض (r ( ب الي تصميم كتاب الكتروني قائم

على المستحدثات الإكترونية لتقديم مادة التربية الفنية بما بناسب مقرر الصف الأول من الحلقة الثانية من التعليم الاساسي، وتحديد فعالية النموذج المقترح للكتاب الإككتروني على (التحصبل المعرفي - اكساب المهارات المنتوعة، المهارات المعلوماتية، ومهارة التعليم الذاتي) مقارنة بالطرق التقليدية، وتوصلت النتائج الي ان استخدام الكتاب الإلكتروني له اثز فعال في تتمية مستوى التحصيل وفى تتمية المهارات الفنية ومهارة التعليم الذاتي لدى التلمبذات لمقرر التربية الفنية، وان الكتاب الإلكتروني يتيح للتلميذات تتمية قدراتهن على البحث: واسترجاع المعلومات في أي وقت. كما أوصت بعض الدراسات بضرورة توظيف الكتب الإلكترونية وتصميمها والاستفادة منها والتوسع في استخدامها واستكثاف فوائدها في العملية التعليمية لتحقيق اقصي استفادة مدكنه منها في التعليم حيث أوصت دراسة كل من: ايمان أحمد (10 ب) الي التوجه لتوظيف الكتب الإلكترونية في مواد تعليمية مختلفة، وإجراء دراسات لاستخدام الكتاب الإلكتروني علي التلاميذ من ذوي الاحتياجات الخاصة والمتأخرين دراسيا. ودراسة بدرية عمر (r/ (r) بضرورة الاهتمام بإنشاء وتصميم الكتب الإلكترونية التعليمية. ودراسة محمود

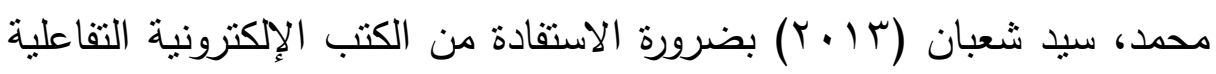
في تتمية المهارات العملية المختلفة. ودراسة مشاعل محمد (ب ا ـ ب) بالتوسع في 
تنمية مهارات تصيميم القصة الرقمية باستخدام الكتاب الإلكتروني وعلاقتها بمستوي طموح معلمي المرحلة الابتدائية

Fenwick, مجال استخدام الكتب الإلكترونية التعليمية في كافة المراحل. ودراسة بتوسيع تجربة استخدام الكتاب الإكتروني ليشمل Jr et al (2013: 135-140) مقررات جامعة أخرى. ودراسة (2013: 155-170 مأن هنالك حاجة إلى استكثاف الفوائد والتحديات المحتملة لبيئات التعلم أكثر انفتاحا وتفاعلية التي هي جزء لا يتجزأ ضمن سياق الدورة الدراسية، منل الكتب المدرسية الإكترونية.

كما قدم مؤتمر آبل "التعليم، رؤية مستقبلية" (apple, 2012) والذي عقد بنيويورك في يناير r ا • Y، مفهوم جديد وهو Text Books الإصدار الثاني وهو مفهوم جديد للكتب الإكترونية التفاعلية والذي يتميز بدعم الكتب الجديدة المحسنة Textbooks، وتحسين خصائص اللمس المتعدد، وامكانية اضافة محتوى اكثر تفاعلاً سواء فيديو أو صور أو رسوم بيانية، وتحديد النصوص

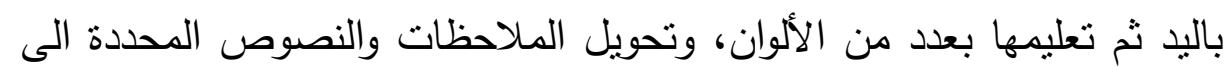
بطاقات للاراسة لتسهيل حفظها، وامكانية عرض معاني الكئي الكلمات بدون الخروج من الصفحة، كما اطلقت تطبيق جديد يدعى iBook's Author ويمكن المستخدم او الناشر من تأليف الكتب التفاعلية بسهوله عالية وبدون خبره مسبقه، وهو مجانى يمكن لأى شخص تحميله. يعد مستوى الطموح الهدف التي يضعه الفرد لذاته في مجالات تعليمية أو مهنية أو أسرية أو اقتصادية ويحاول تحقيقه ويتسم بالعديد من المؤثرات الخاصة بشخصية الفرد أو القوى البيئية المحيطة به وإذا نتاسب مستوى بهى الطموح مع إمكانيات الفرد وقدراته الحالية والمتوقعة كانت السوية، وإذا لم لم

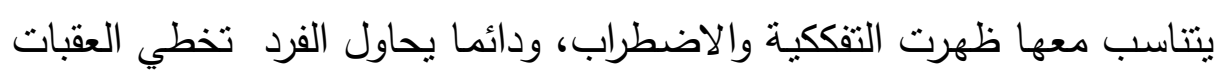
التي تحول دون تحقيق أهدافه أو تعرقلها واحيانا أخرى يفشل ويحبط ويقل مستوى طموح الفرد، ويعد مستوى الطموح عامل واقعي للأداء والتفوق كما يعد من خصائص الثخصية الصلبة التي تتحمل الضـوط وتتصف بالتحدي 
تنمية مهارات تصيميم القصة الرقمية باستخدام الكتاب الإلكتروني وعلاقتها بمستوي طموح معلمي المرحلة الابتدائية

$$
\text { والضبط والالتزام آمال عبدالسميع (ع . . Y: Y). }
$$

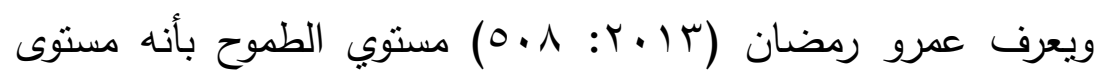
النجاح الذي يرغب الفرد في تحقيقه والوصول إليه، وذلك في ضوء الأهداف التي قام بوضعها مسبقا والتي تتوافق مع إمكاناته واستعداداته.

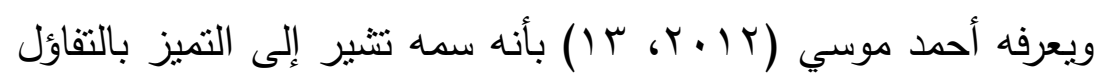

والمقدرة علي وضع الأهداف وتقبل كل ما هو جديد وتحمل الفشل والاحباط.

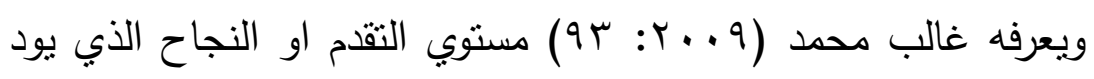
الفرد ان يصل اليه في مجال يرغبه من خلال معرفته لإمكاناته وقدراته والاستفادة من خبراته التي مر بها.

Richard M, R; Edward L, D (2008: وهناك مستويات للطموح قسمها ميرها :667) طموح داخلي: يعبر عن النمو الموروث والذي يؤدي الي اشباع الحاجات النفسية الأساسية (الكفاءة، الاستقلال، الانتماء).

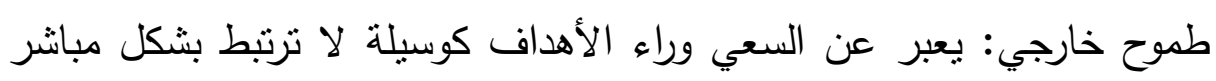
بإثباع الحاجات النفسية الأساسية. وهناك جوانب تميز الطموح يحددها صلاح أحمد (9199 1: الجانب الأول: الأداء ويعني ذلك نوع الأداء الذي يعده الفرد هاما ويرغب في القيام به في عمل من الاعمال.

الجانب الثاني: التوقع ويعني ذلك نوقع الفرد لأدائه لهذا العمل أو ذاك. الجانب الثالث: الأهمية ويعني ذلك إلى أي حد يعد هذا الأداء مهمًا بالنسبة للفرد.

وهذه الجوانب الثلاثة هي ما يعرف بالطموح غير ان هناك فرق بين نوعين من الطموح طموح ايجابي، طموح سلبي ويتمنل الطموح الايجابي في النزعة لتحقيق نجاحات مستمرة بينما يتمثل الطموح السلبي في محاولة تجنب مزيد من الفشل طبل 
تنمية مهارات تصيميم القصة الرقمية باستخدام الكتاب الإلكتروني وعلاقتها بمستوي طموح معلمي المرحلة الابتدائية

وهناك طبيعة لمستوي الطموح حدنها كاميليا عبدالفتاح (ع 9 ( : Y I)

مستوي الطموح كاستعداد نفسي: المقصود أن البعض من الناس لديهم الميل إلى

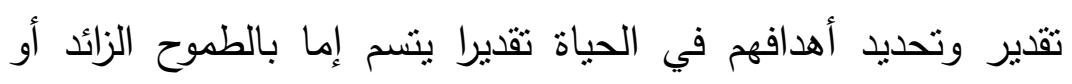

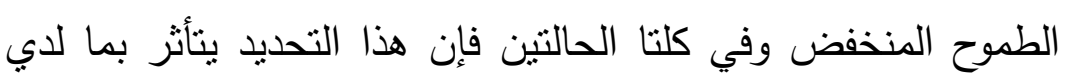
الفرد من عوامل تكوينية وعوامل التدريب والتربية والتنشئة. مستوي الطموح كإطار تقدير وتقويم الموقف: ويتكون هذا الإطار من عاملين أساسين:

الأول: التجارب الثخصية التي يمر بها الفرد والتي يعمل علي تكوين أساس يحكم به علي مختلف المواقف والأهداف. الثاني: أثز الظروف والقيم والعادات واتجاهات الجماعة في تكوين مستوي الطموح. مستوي الطموح كسمة: والسمة ما يميز بين الناس من حيث كيفية تصرفهر وسلوكهم ولهذا نجد استجابات الناس متعددة تجاه موقف واحد، فلكل سماته التي تميزه، وهذه السمة ليست مطلقة بل هي ثابته نسبيا ولهذا نجد تأثير مستوي الطموح بما لدي الفرد من استعدادات فطرية

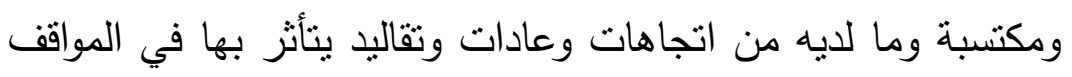
والظروف، فهناك ربط بين مستوي طموح الفرد وعوامل اخري تتعلق بالتكوين النفسي والتدريب والتتشئة الاجتماعية بما تحويه من قيم وبري وعادات واتجاهات وتقاليد والتجارب والخبرات التي يمر بها والتي تشكل اطاره المرجعي فيتبادل الاثر والتأثير بين هذه العوامل وبين مستوي الطموح.

وهناك سمات للثخص الطموح توضحها اسماء محمد (11 • ؟: . ؟) كالآتي: لا يشعرون باليأس ولديهم طموحات مرتفعة، وينجزون ويعتمدون علي 
تنمية مهارات تصيميم القصة الرقمية باستخدام الكتاب الإلكتروني وعلاقتها بمستوي طموح معلمي المرحلة الابتدائية

انفسهم، أهدافهم واضحة دائما وواقعية ومناسبة لقدراتهم، وبسعون دائما لمعرفة كل جديد مع مواكبة العلم والتطور في المعرفة، ويتحملون المسئولية ويكافحون

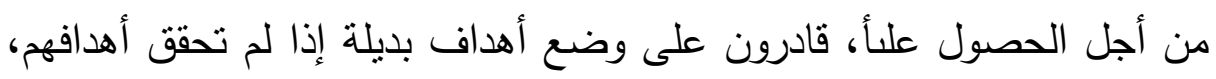

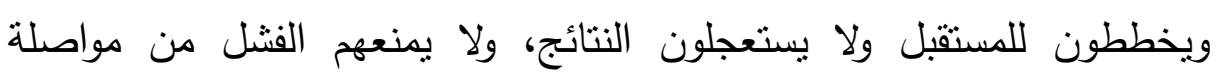

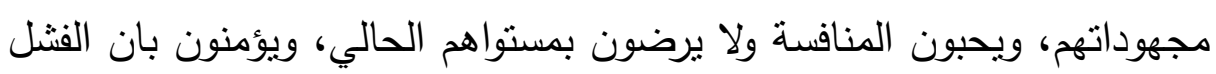
هو اول خطوات النجاح. وللنجاح دورا كبيرا في تتمية مستوي الطموح فاذا ما نجح الفرد وتفوق زاد طموحة ويظل الفرد مثابرا للمحافظة علي ما حصل علية من تفوق، ونجاح الفرد يمكن أن يأتي من خلال تدريبة تدريبا جيدا، واستخدام الوسائل التي تساعده على هلى هذا النجاح، وقد أظهرت بعض الدراسات تتمية مستوي الطموح لدى المتعلمين في المراحل المختلفة بعد استخدام وسائل نساعدهم على النجاح، فأوضحت

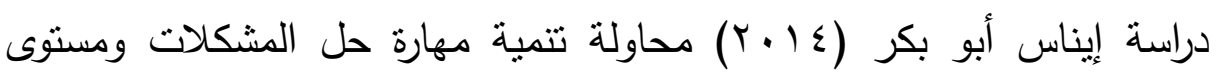
الطموح وتقدير الذات لاى أطفال الروضة ذوي صعوبات التعلم من خلال تصميم برنامج كمبيوتز متعدد الوسائط، وتوصلت الدراسة إلى فاعلية برنامج الكمبيوتز في تحسين درجات أطفال الروضة ذوى صعوبات التعلم في اختبار حل المشكلات، ومستوي الطموح، وتقدير الذات في اتجاه القياس البعدي،

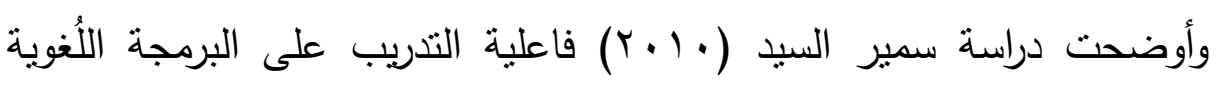

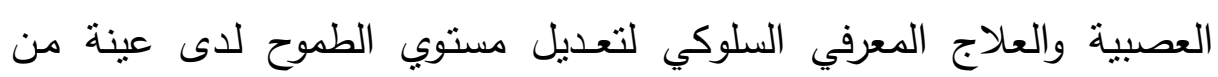
المراهقين ذوي الإعاقة السمعية وأثزه في السلوك التكيفي، وتوصلت نتائج الدراسة إلى فاعلية كلٍ من التدريب على البرمجة اللغوية العصبية والبرنامج المعرفي السلوكي لتعديل مستوي الطموح لدى عينة من ذوي الإعاقة السمعية، واستمرارية الفاعلية بعد مرور فترة من تطبيقه.

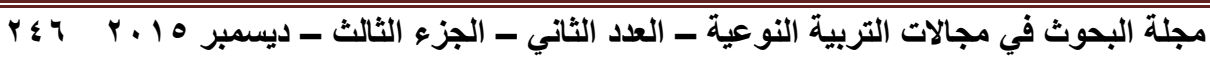


تنمية مهارات تصميم القصة الرقمية باستخدام الكتاب الإلكتروني وعلاقتها بمستوي طموح معلمي المرحلة الابتدائية

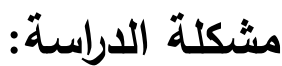

أضحت مهارات تصميم القصص الرقمية من المهارات التي ينبغي أن

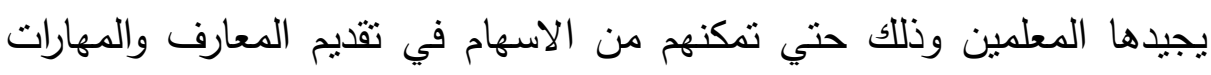

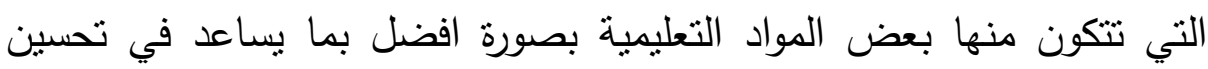
وتيسير العملية التعليمية.

وقد أكدت كثير من الدراسات أهمية دراسة مهارات القصة الرقمية وفائدة

Hung, C; Hwang, G; Huang, I (2012: 368-379) تعلمها، فقد أكدت دراستة أهمية دراسة مدخل القصص الرقمية القائمة علي المشروع في تتمية التحصيل الدراسي والدافعية للتعلم ومهارات حل المشكلات لدي تلاميذ المرحلة الابتدائية،

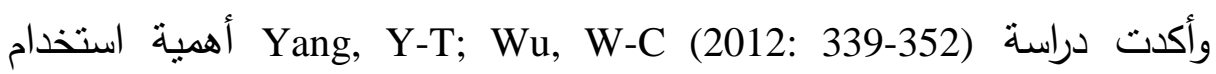

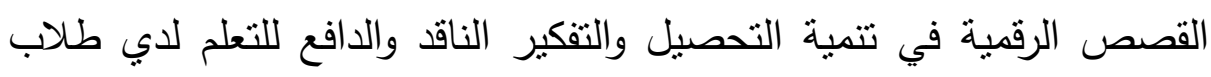

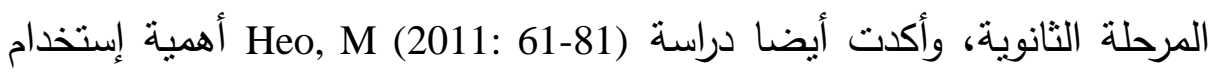
القصص الرقمية في برامج إعداد المعلم لرفع كفاءتهم التدريسية باستخدام التكنولوجيا، واستخلصت دراسة (Kieler, L (2010:48-52) مجموعة من الفوائد التزبوية لاستخدام القصص الرقمية مع الطلاب الموهوبين في الفصول متل

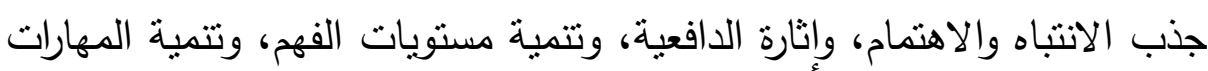

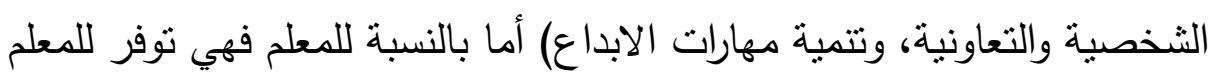
وسائل تعليمية مختلفة تلبي احتياجات ومصالح المتعلمين، وتوصلت دراسة

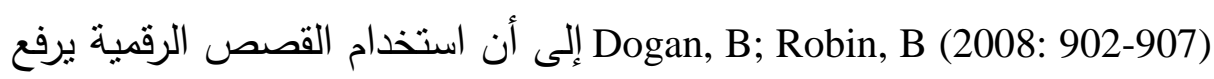
من مستوي المهارات التقنية ومهارات العرض لإي الطلبة كما يرفع من مسنوبي

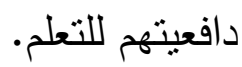

وأوصت كثير من الدراسات والبحوث بضرورة تعلم مهارات القصة

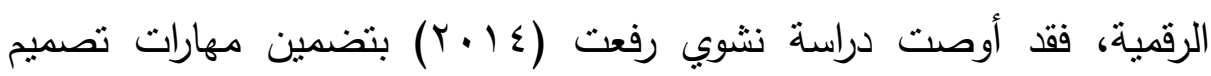


تنمية مهارات تصيميم القصة الرقمية باستخدام الكتاب الإلكتروني وعلاقتها بمستوي طموح معلمي المرحلة الابتدائية

وتطوير القصة الرقمية التعليمية في بعض مقررات برامج الدراسات العليا،

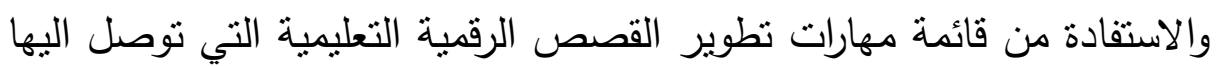
البحث في تدريب اخصائي تكنولوجيا التعليم والطلاب المعلمين علي القصة

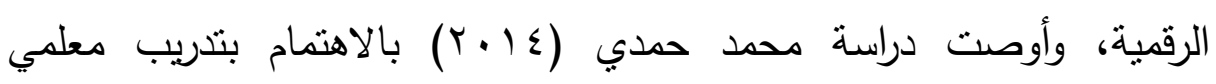
ومعلمًات المراحل التعليمية الأولي علي كيفية تصميم وتقديم القصص الرقمية بمقرراتهم، وكذلك اكساب المعلمين مهارات توظيف القصص الرقمية في مواقف

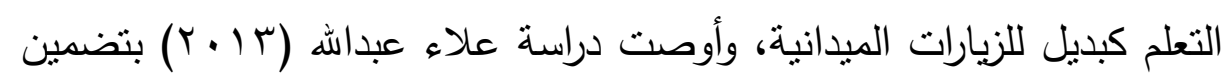
مهارات تصميم واستخدام القصص الرقمية التاريخية في بعض مقررات برامج إعداد معلم التاريخ بكليات التربية قبل الخدمة، وتدريب المعلمين علي تصميم واستخدام القصص الرقمية، وإشراك التلاميذ مع المعلم في عملية تصميم

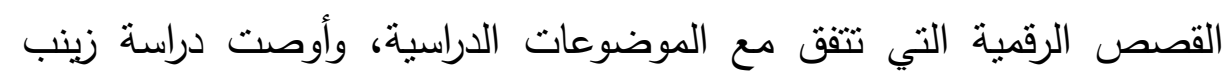

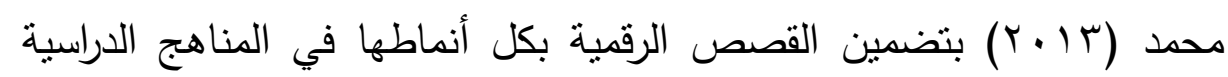

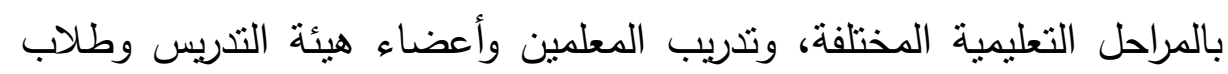

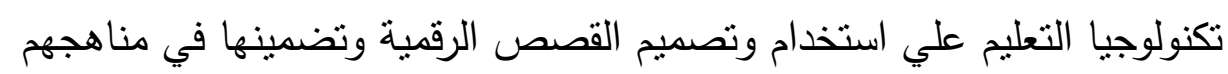

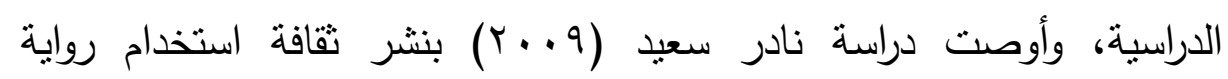
القصص الرقية فيما بين الأوساط التعليمية وبتدريب أعضاء هيئة التدريس

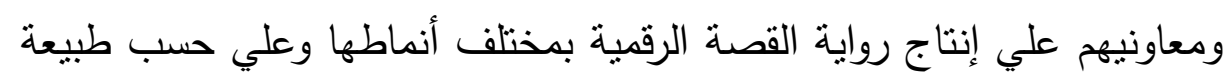
المحتوي العلمي، والاهتمام بتضمين التعريف برواية القصص الرقمية وأساليب التبه إنتاجها في برامج إعداد المعلم الجامعي.

وأجري الباحث دراسة استطلاعية عبارة عن استبيان لمعرفة مدى توفر

مهارة تصميم القصة الرقمية لاي مجموعة مكونة من ( • (Y) من معلمي المرحلة الابتدائية وتضمن الاستبيان مجموعة من الاسئلة المغلقة التي تهدف الي

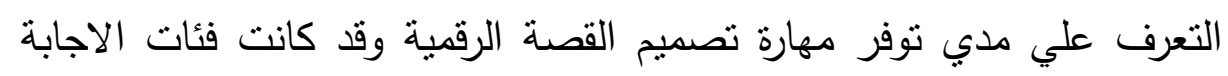

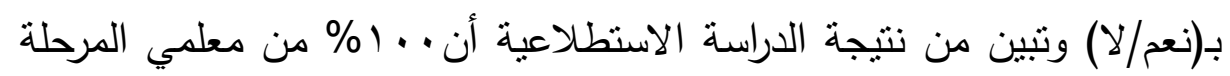


تنمية مهارات تصيميم القصة الرقمية باستخدام الكتاب الإلكتروني وعلاقتها بمستوي طموح معلمي المرحلة الابتدائية

الابتدائية لا يمتلكون مهارة تصميم القصة الرقمية، كما أبدي . . 1\% رغبتهم في تعلم كيفية اعداد قصة رقمية، وعلى هذا الاساس يمكن تحديد مشكلة الدراسة الحالية في تتمية مهارات تصميم القصة الرقمية باستخدام الكتاب الإلكتروني وعلاقتها بمسنوي طموح معلمي المرحلة الابتدائية.

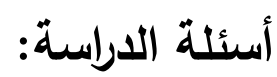

1- ما التصور المقترح للكتاب الإلكتروني لتتمية مهارات تصميم القصة الرقمية؟ ץ-ما فاعلية الكتاب الإكتروني في تتمية الجانب المعرفي لمهارات تصميم

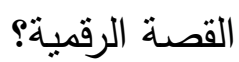
r-ما فاعلية الكتاب الإككتروني في تتمية الجانب الادائي لمهارات تصميم القصة الرقمية؟

ع- هل هناك علاقة ارتباطية بين مستوي الطموح ومهارات تصميم القصة الرقمية؛

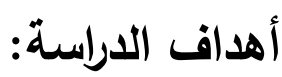
هدفت الدراسة إلى الارتقاء بمستوى :

- - مهارات تصميم القصة الرقمية الواجب توافرها لدي مجموعة الدراسة. - فاعلية الكتاب الإكتروني علي تتمية كل من الجانب المعرفي والادائي لمهارات تصميم القصة الرقمية لدي مجموعة الدراسة. - علاقة مستوي الطموح ومهارات تصميم القصة الرقمية. أهمية الدراسة: قد تقيد الدراسة الحالية في: - لفت نظر القائمين علي العملية التعليمية الي ضرورة استخدام الكتب لهبه الإككترونية في العملية التعليمية لتطوير وتحسين أساليب التعلم باستخدام الأساليب التكنولوجية الحديثة. 
تنمية مهارات تصيميم القصة الرقمية باستخدام الكتاب الإلكتروني وعلاقتها بمستوي طموح معلمي المرحلة الابتدائية

- رفع كفاءة مهارة تصميم القصة الرقمية لدي معلمي المرحلة الابتدائية مجموعة الدراسة مما ينعكس علي جودة التعليم.

- الكثف عن مستوي طموح معلمي المرحلة الابتدائية باعتبار أن الطموح يتعلق باتزان شخصياتهم ويمثل علامة مهمة من علامات الروح المعنوية العالبة لهم.

- تحديد طبيعة العلاقة بين مهارات تصميم القصة الرقمية ومستوي الطموح كمتغير يؤثز في مستوي اداء الفرد.

\section{فروض الاراسة:}

- لا يوجد فرق دال إحصائيًا عند مستوي (1 (..) بين متوسطي درجات التطبيقين القبلي والبعدي لاختبار التحصيل في الجانب المعرفي المتعلق بتصميم القصة الرقمية.

- لا يوجد فرق دال إحصائيًا عند مستوي (1 (..) بين متوسطي درجات التطبيقين القبلي والبعدي لبطاقة تقييم المهارة لمهارات تصميم القصة الرقمية.

- ل ال توجد علاقة ارتباطية دالة إحصائيًا عند مستوي (1 (..) بين مستوي الطموح ومهارات تصميم القصة الرقمية.

حدود الدراسةة:

الحدود الزمانية: تم تطبيق الدراسة الحالية خلا الفصل الدراسي الأول للعام

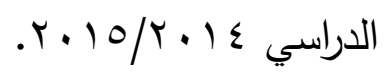

الحدود المكانية: مدرسة الصفوة الابتدائية (ب) مُعلم، مدرسة عمر بن عبدالعزيز الابتدائية ( • r) مُعلم، بادارة قنا التعليمية، بمحافظة قنا .

الحدود البشريـة: اقتصرث الدراسة علي مجموعة من معلمي المرحلة الابتدائية

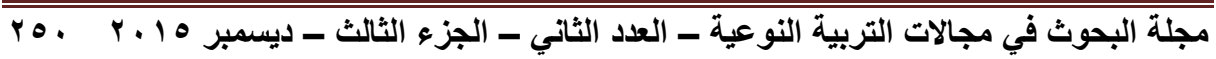


تنمية مهارات تصميم القصة الرقمية باستخدام الكتاب الإكتروني وعلاقتها بمستوي طموح معلمي المرحلة الابتدائية

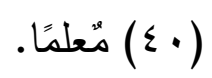

الحدود الموضوعية للمتغير المستقل: الكتاب الإكتروني.

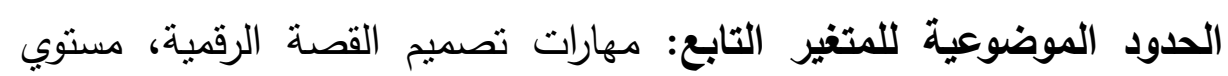
الطموح.

\section{مصطلحات الاراسة:}

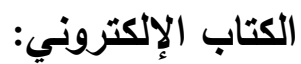

يعرف إجرائيًا بأنه وسيط معلوماتي تم إعداده بطريقة الكترونية بإستخدام

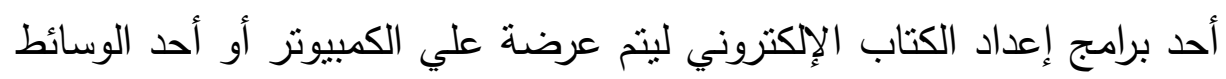
الإلكترونية ويكون متاحا علي أسطوانات CD أو علي شبكة الإنترنت. القصة الرقمية:

تعرف إجرائيًا بأنها دمج النصوص والصور ثلاثية الأبعاد والرسوم والسرد المسجل، والخلفيات التصويرية والموسيقية باستخدام أحد برامج إعداد القصة الرقمية لتصميم قصة رقمية.

مستوي الطموح:

يعرف إجرائيًا بأنه المستوي الذي يرغب الفرد في الوصول إليه أو يشعر

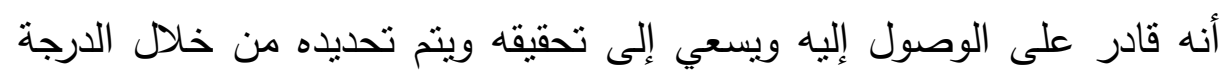
التي يحصل عليها المستجيب من خلال إجاباته عن بنود مقياس مستوي الطموح المستخدم في هذه الدراسة.

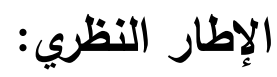
(1/1/1) ماهية الكتاب الإكتروني:

يختلف تعريف الكتاب الإكتروني باختلاف المحور الذي يتم التعريف

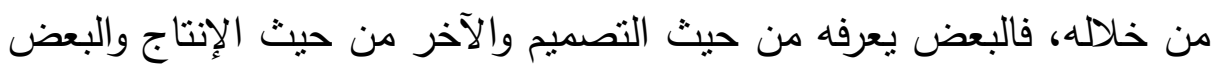

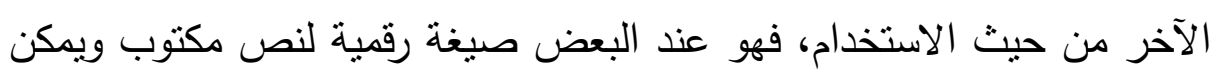


تنمية مهارات تصيميم القصة الرقمية باستخدام الكتاب الإلكتروني وعلاقتها بمستوي طموح معلمي المرحلة الابتدائية

قراءة محتوياته على أجهزة الحاسب أو الأجهزة الكفية أو باستخدام أجهزة

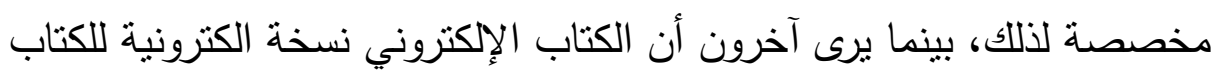

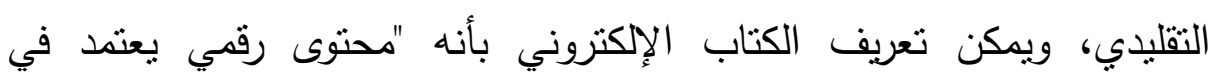
تصميمه وإنتاجه على الوسائط المتعددة من نصوص مكتوبة ومنطوقة وصور ورسوم ثابتة ومتحركة ولقطات فيديو، بحيث يعرض محتوى المادة التعليمية بشكل رقمي لتعرض على شاثنة الكمبيوتز ، ويمكن المتعلم والمعلم من استخدامه

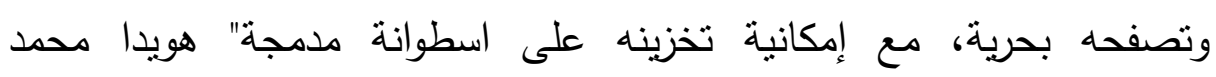

$$
\cdot(1 V: r \cdot 1 \varepsilon)
$$

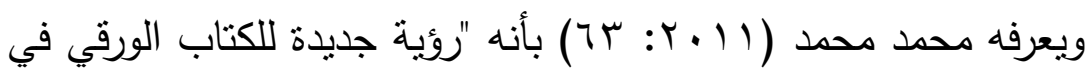

صورة إلكترونية مع إضافة عناصر الوسائط المتعددة والنصوص الفائقة والبحث، وهو بهذا يجمع بين سمات الكتاب الورقي المطبوع وسمات الوسائط المتعددة،

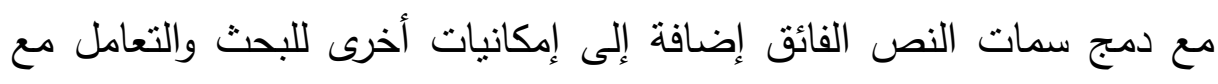

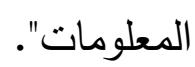

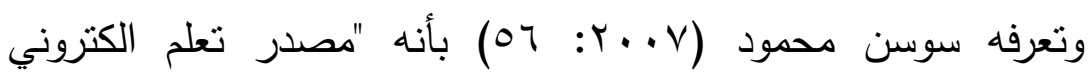

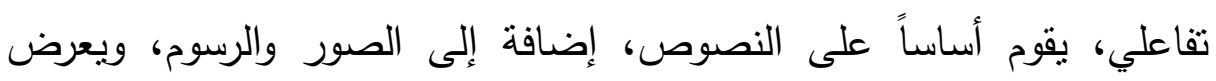
محتواه بطريقة منتعبة أو خطية تقوم على أساس العقد والوصلات، ويتمكن المستخدم من تصفحه بحرية تامة، ويتم تخزينه على CD-ROM أو عرضه

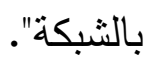

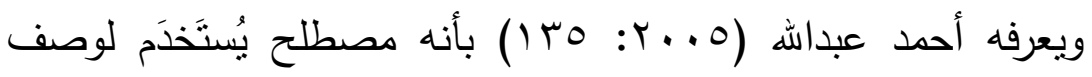
نص مشابه للكتاب يُعرَض على شاشة الحاسب الآلي (الحاسوب) مرتبطاً ارتباطاً نكنولوجياً بالفيديو التفاعلي، ويتم استخدامه بإيجابية في نظام التعليم عن بنابن بعد، ويعد الكتاب الإكتروني مصدراً من مصادر المعلومات الإلكترونية التي بالئي يمكن استثمارها في تتفيذ مناهج ومقررات التعليم عن بعد. بعدي مما سبق يمكن استخلاص أن الكتاب الإكتروني:

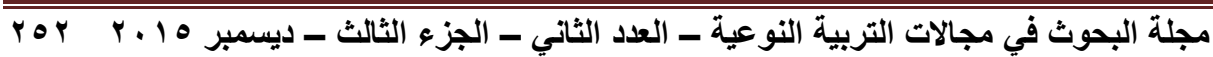


تنمية مهارات تصيميم القصة الرقمية باستخدام الكتاب الإلكتروني وعلاقتها بمستوي طموح معلمي

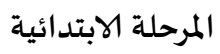

- - محتوى علمي، نقافي أو تعليمي أو غيره. - محفوظ بطريقة من الطرق الإلكترونية على وسائط تخزين، أو أجهزة متخصصة لقراءة الكتب الإلكترونية. - يتكون من الوسائط المتعددة المتمثلة في النصوص والصور الثابتة

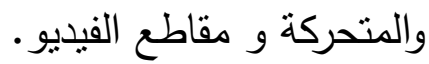

- منه ما هو تفاعلي، ومنه ما هو غير تفاعلي يقتصر على عرض المعلومات دون وجود أي تفاعل وبصورة مشابهة للكتاب الورقي التقليدي. - لقراءته لابد من استخدام جهاز الكمبيوتز المكتبي أو المحمول أو اللوحي، كما بمكن استخدام الهواتق المحمولة الحديثة. - يمكن نشره على شبكة الإنترنت مما يتيح سهولة تداولها وإمكانية استيراد الكتب الإلكترونية من الأماكن البعيدة.

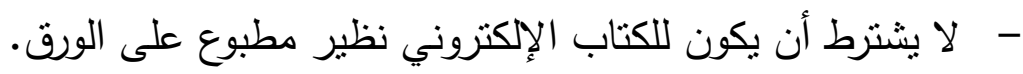

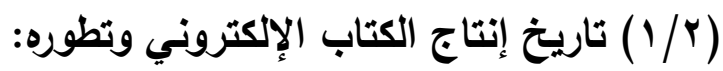

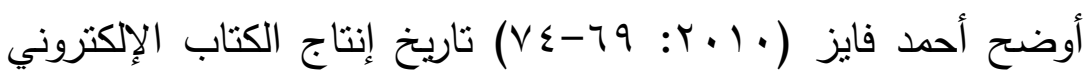
(Sharpe, وتطوره تبعا لما اوردته بعض الادبيات مثل (شريف كامل، ... (Wikipedia) فيما يلي: (Wilson, R 2004) (2000) أن معظم الأفكار التي تطرح تبقي مجرد أفكار لفترة طويلة قبل أن تتمكن التكنولوجيا من تحقيقها وهذا ما حدث للكتاب الإلكتروني، ويعد Vannevar Bush الكتاب الإلكتروني وذللك من خلال الآلة Memex حيث قام في أوائل عام • ب9 19كتابة مقال عن هذه الآلة وقد تخيل أن الآلة Memex مرتبطة آليا. بالمكتبة ويمكنها عرض الكتب والأفلام الموجودة بها كما تتيح إمكانية إنشاء روابط للمعلومات إضافة إلى عرض هذه الروابط وتدمج هذه الآلة بين أدوات التحكم الآلية وكاميرات الميكروفيلم والقارئات معا في جهاز واحد كبير. 
تنمية مهارات تصميم القصة الرقمية باستخدام الكتاب الإلكتروني وعلاقتها بمستوي طموح معلمي المرحلة الابتدائية

وكان مقال Vannevar Bush وثيقة مزواجة لتقنيات الحاسب والاتصالات من ناحية مع قطاع حفظ الإنتاج المعرفي من ناحية أخري وعلي

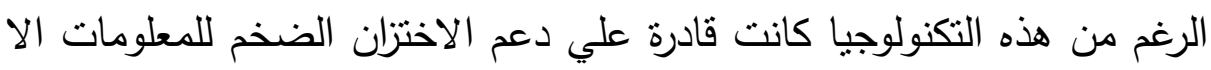
أن استرجاعها من خلال روابط فيما بينها كان أمرا مستحيلا يصعب تتفيذه لذلك الكي تأخر التنفيذ منتظرا التكنولوجيا التي تدعمه. وتوصل Alan Kay إلى أن بطور أول حاسب إلى محمول وهو عبارة عن حاسب في حجم الكتاب وأسماه Dynabook ويشبه الحاسب الآلي الحديث laptop ويمكن الوصول إلية مثل الكتاب الورقي وبهذا يعد Alan Kay أول من صمم شاشة عرض مسطحة وأول من استخدم الصور والرسوم المتحركة.

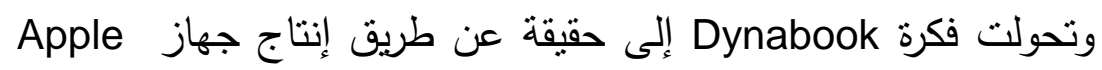
Newton Message Pad ويمكن للجهاز عرض العناوين الإلكترونية في صيغة كتاب Newton Book مع

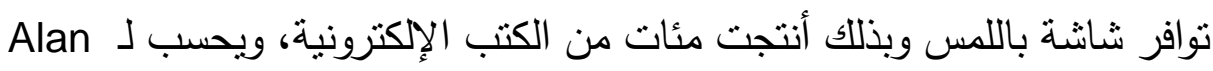
ابتكاراته في مجال استخدام الرموز والايقونات في البرمجيات بدلا من Kay الكلمات للالالة علي وظائف أو ملفات داخل الحاسب. Andries Van Dam ويرجع مصطلح الكتاب الإلكتروني الي العالم الذي تركزت اهتماماته وأبحاثه حول رسوم الحاسب الالي وأنظمة الوسائط الفائقة والبرامج التعليمية كما عمل علي أنظمة إنتاج الكتب الإلكترونية وقراءتها لما يقرب من اربعين عاما ليمكن استخدامها في التدريس والبحث.

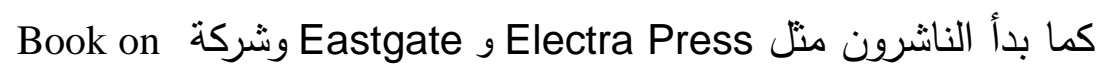
تجربة حفظ الكتب الإلكترونية علي الاقراص المرنة في اواخر السبعينات وخلال الثمانينات ولكنها كانت ذات سعة منخفضة ولها نفس مشكلات القراءة من علي الثاشة وتستهدف الغرض التعليمي فقط، كما لم يكن للكتب علي 
تنمية مهارات تصميم القصة الرقمية باستخدام الكتاب الإكتروني وعلاقتها بمستوي طموح معلمي المرحلة الابتدائية

القرص المرن تأثير كبير علي أي من سوق المستهلك او صناعة النشر فيما عدا بعض الاسواق الخاصة. كما قام منتجو الكتب الإلكترونية الاوائل بتحويل الكتب الورقية إلى كتب الكترونية عن طريق مسحها ضوئيا باستخدام نظام التعرف الضوئي OCR ثم أتيحت في صيغة نص اسكي لإمكانية تحميلها بسهولة من علي الإنترنت، ثم ظهر برنامج أدوبي اكروبات كبرنامج تجاري لنشر النص الإكتروني وعرضها، وقد عقد أول مؤتمر سنوي عن الكتاب الإلكتروني برعاية المعهد القومي للمعايير

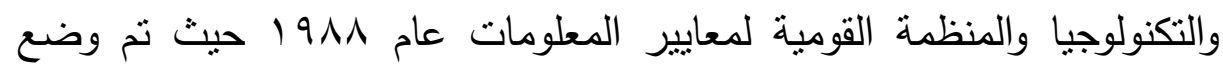
الاساس لمجموعة عمل مبادرة الكتاب الإلكتروني المفتوح لمناقثنة معايير المنتج الجديد والقضايا المتعلقة به.

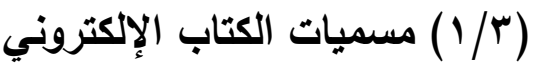

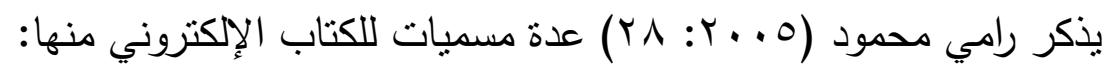
Hypertext book E-Book النصوص المهيبرة

Multimedia book Digital book المتعددة

Extended book Web book الممتد On line book Virtual book المباشر Computerized book للتحميل 
تنمية مهارات تصيميم القصة الرقمية باستخدام الكتاب الإلكتروني وعلاقتها بمستوي طموح معلمي

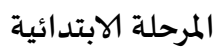

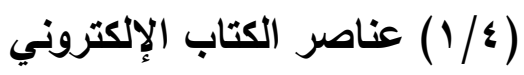

هناك عناصر للكتاب الإلكتروني أوردها محمود عبدالكريم، هاشم

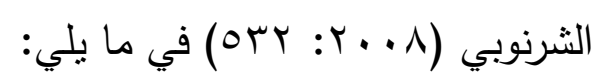

أ. النصوص وعناصر الوسائط المتعددة: تعتمد الكتب الإلكترونية في معظمها على النصوص، لأنها الجوهر الأساسي والهدف المقصود من إعداد وتصميم الكتب الإكترونية، وتثنل الكتب الإلكترونية على الصور والرسومات الثابتة

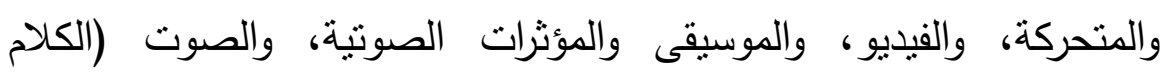
(المنطوق).

ب. مساحات التفاعل وتدوين ملاحظات الطالب: مساحات وقوالب ومربعات تتسم بها بعض الكتب الإلكترونية لتتيح للمتعلم تدوين ملاحظاته، أو إعداد

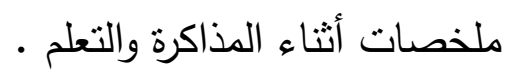
ج. صفحات الكتاب (مساحة العرض): وتكون غالباً مصممة على شكل صفحة

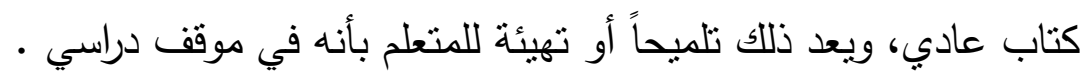
د. واجهة التفاعل: تشتمل على الأدوات والطرق والمسارات المتاحة للمتعلم

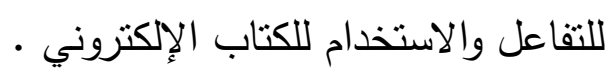
هـ الروابط والوصلات: تتسم بعض الكتب الإلكترونية المتاحة على شبكة

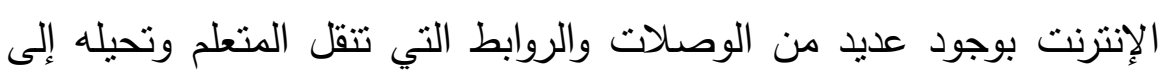

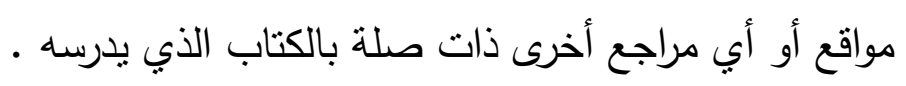

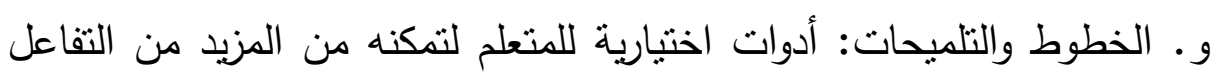

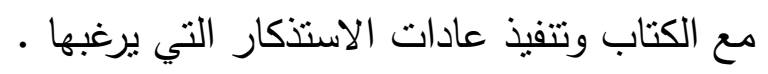
(1/0) أنواع الكتاب الإلكتروني: هنالك أنواع من الكتب الإلكترونية يمكن نوضيحها فيما يلي: ا. الكتب الإكترونية النصية: كتب تعتمد نص مكتوب لكتاب مطبوع وهذا النص يسمح من خلاله بالبحث عن أي كلمة في الكتاب الإكتروني 
تنمية مهارات تصيميم القصة الرقمية باستخدام الكتاب الإلكتروني وعلاقتها بمستوي طموح معلمي المرحلة الابتدائية

والوصول اليها بسهولة وهذه الكتب تتميز ببساطتها وسهولة انشاؤها. r. الكتب الإكترونية النصية المصورة: كتب تعتمد علي صورة مكتوبة مسحوبة وهنة

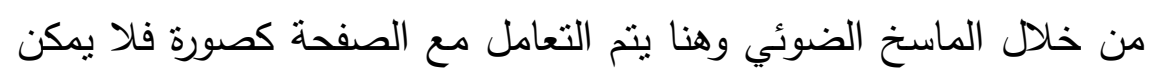
البحث عن كلمة موجودة داخل الكتاب الإلكتروني ولكن من الممكن البحث عن عنوان فصل من الفصول اذا كان مكتوبا كنص. r. الكتب الإكترونية التفاعلية: كتب تعتمد علي النص مع الصوت والصورة والفيديو والروابط التشعبية وهذا يعطي الكتاب الإككتروني ميزة كبيرة في الشرح والاستخدام في العملية التعليمية. ( (1/7) الخصائص الفنية للكتاب الإلكتروني: يتميز الكتاب الإلكتروني بمجموعة من الخصائص الفنية التي أثنار لها

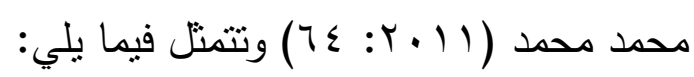
ا. النص Text: من الممكن استخدام أي خط في الكتاب الإككتروني بأي حجم

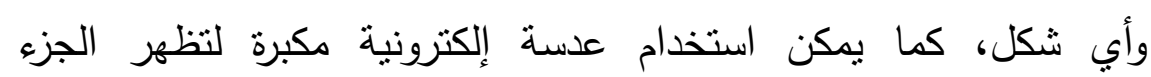
المطلوب من النص بنسبة التكبير المطلوبة أياً كانت، ويمكن عرض الكنرونة النص

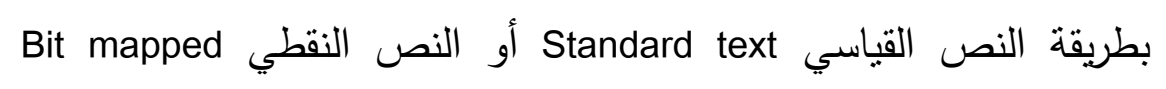
أو النص المتحرك Amage

$$
\text { للفصول والموضوعات. }
$$

r. الرسوم Graphics: من الممكن أن يحتوي الكتاب الإلكتروني على عدد كبير

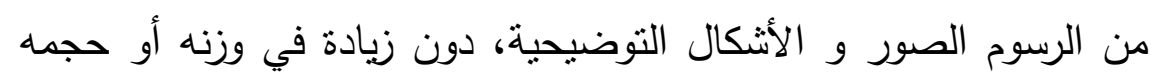

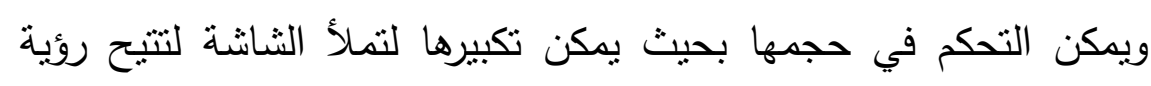
أوضح

r. نظام الإبحار Navigation System: يتيح الكتاب الإلكتروني استخدام أنماط مختلفة من الإبحار والتجول داخل الكتاب الإلكتروني منل خرائط الإبحار أو جداول المحتويات مع الروابط الخاصة بها وكذلك خاصية البحث عن

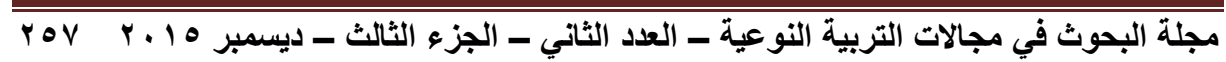


تنمية مهارات تصميم القصة الرقمية باستخدام الكتاب الإلكتروني وعلاقتها بمستوي طموح معلمي المرحلة الابتدائية

كلمة أو جملة وينبغي أن يستخدم أنظمة إبحار قوية للربط بين أجزاء

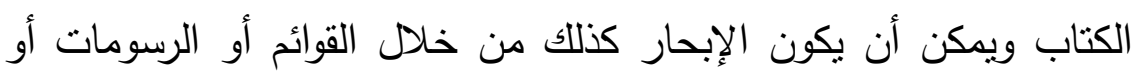
الوصلات الفائقة.

ع. الوصلات لفائقة Hyperlinks: يراعى في الوصلات المستخدمة قدرتها على

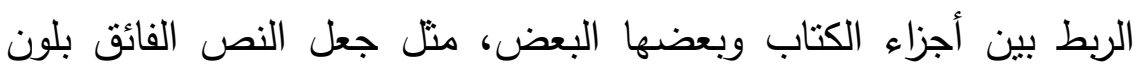
مختلف لتميزه عن باقي النص.

ه. خاصية البحث Search Feature: يزود الكتاب الإلكتروني بأداة للبحث عن بـ إئ

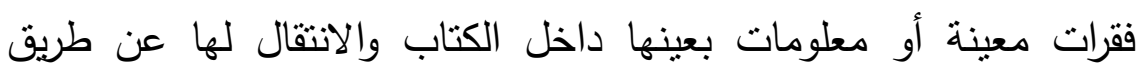
البحث وهذا أسهل كثيرا عنه في الكتب المطبوعة.

7. الصوت Sound: قد يحتوي الكتاب الإكتروني على أصوات معينة مثل أصوات الموسيقى أو التعليق الصوتي أو أصوات طبيعية. V. الرسوم المتحركة والفيديو Animation and Movies: قد تحتوى الكتب اون الإلكترونية على رسوم متحركة مدعمة بالألوان كما يمكن أن تحتوى على لرئ لقطات فيديو خاصة بالمحتوى المعروض. 1. المحاكاة التفاعلية Interactive Simulations: قد تحتوى بعض الكتب الإككترونية على أنماط من المحاكاة عن طريق صور يمكن للقارئ استعمالها ونقلها من مكان إلى آخر، منل: تتفيذ تجارب الكيمياء والتفاعلات الكيميائية وما يصاحب ذلك من تغيير في اللون أو التسخين أو الونياء انفجارات، كل هذا يحث على الثاشة كما لو كان حقيقياً. 9 ـ مؤتمرات الفيديو Video Conferencing: يمكن من خلال الاتصالات الحديثة أن يتاح في الكتاب الإكتروني تكنولوجيا حديثة، بحيث يمكن عن طريق

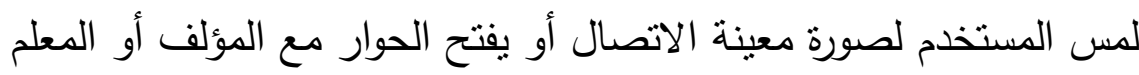

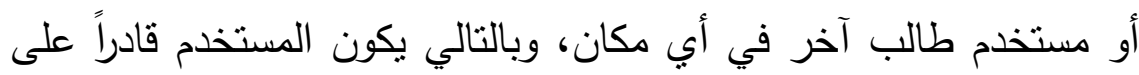
عرض الأسئلة والتفاعل مع المؤلف أو المعلم، ويمكن أن يكون هنالك ليكان 
تنمية مهارات تصيميم القصة الرقمية باستخدام الكتاب الإلكتروني وعلاقتها بمستوي طموح معلمي المرحلة الابتدائية

اتصال بصري بينهما ويمكن أن يشتركا في لوحة بيضاء "منطقة من الشاشة"، حيث يمكن أن يكتبا فيها تعليقاتهما. • ا. البيئات الافتراضية Virtual Reality Environments: يمكن للكتاب الإكتروني في ظل التكنولوجيا الدديثة أن يسمح للمستخدم بارتداء سماعات

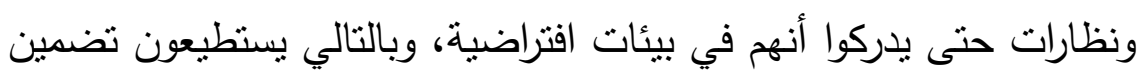
القدرة الثلاثية الأبعاد، وبالتالي يمكن للقراء والطلاب تتفيذ المهام المختلفة

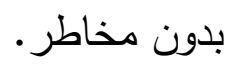

(I/V) مواصفات تصميم محتوى الكتاب الإكتروني: (1/V)

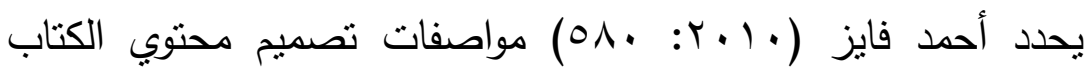

$$
\text { الإلكتروني في: }
$$

الغلاف: الاحتفاظ بمواصفات الغلاف الورقي، مع إضافة مزية عند النقر على

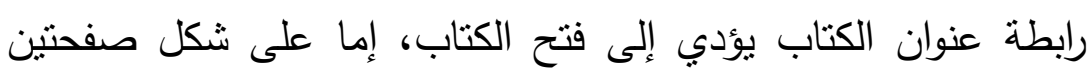
مثقابلتين أو صفحة واحدة حسب رغبة المستفيد.

قائمة المحتويات: عبارة عن قائمة تفصيلية بمحتويات الكتاب، تحتوي على واهلى روابط بالموضوعات الرئيسة والفرعية التي يتضمنها الكتاب، تفيد في إمكانية الوصول إلى العنوان المطلوب عن طريق النقر على رابط العنوان المطلوب في لحظة واحدة.

قائمة الجداول والأثكال: عبارة عن قائمة بالجداول والأشكال وأرقامها والصفحات المدرجة بها وعند النقر على رقم الجدول أو الثكل أو عنوانه أو الصفحة المدرجة يتم الوصول إليه مباشرة.

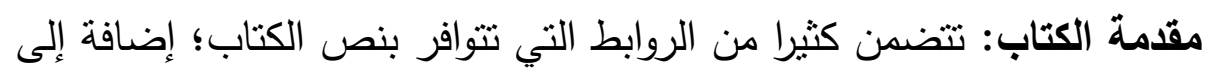
رابطة اسم المؤلف التي تقيد عند النقر عليها في الوصول إلى معلومات عن المؤلف، وكيفية الاتصال به، والاستفسار عن أي معلومات ضمن لهن الكتاب. 
تنمية مهارات تصيميم القصة الرقمية باستخدام الكتاب الإلكتروني وعلاقتها بمستوي طموح معلمي المرحلة الابتدائية

نص الكتاب: يمكن تضمين كثثر من العناصر التفاعلية إلى نص الكتاب التي تساعد على فهم النص واستيعابه بطريقة أسهل وأسرع، ومن هذن لئه العناصر ما يلي:

ا •يجب استخدام ألوان قليلة وثابتة لزيادة جذب الانتباه، كما يجب استخدام الخلفيات العادية وتجنب استخدام خلفيات الصفحات البيضاء؛ لأنها تزبد من لهن صعوبة قراءة النص

r. يمكن تضمين أيقونات في كل صفحة يتم ربطها بالصفحة الآتية والسابقة وقائمة المحتويات والصفحة الأولى والصفحة الأخيرة من الكتاب لسهولة الوصول للصفحة المطلوبة.

r. يمكن تضمين مستخلص وكلمات مفتاحية لكل فصل من فصول الكتاب التي تساعد المستفيدين على فهم محتويات كلّ فصل بلمحة واحدة، كما تساعد روابط الكلمات المفتاحية على الوصول للمصطلح المطلوب في النص بسرعة.

ع. يمكن عرض تعليق لكلمات وعبارات محددة بالكتاب؛ أب عند الوقوف بالفأرة على كلمة محددة يظهر صندوق تلميحي صغير يبين مضمون التعليق الذي يضيفه المؤلف أو الكاتب.

ه. يجب أن تكون الخطوط كبيرة لإمكانية القراءة لفترات طويلة دون أن تسبب

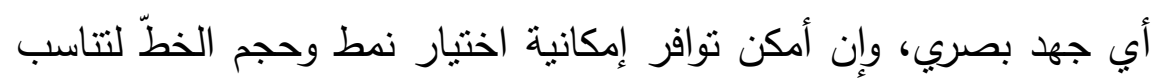

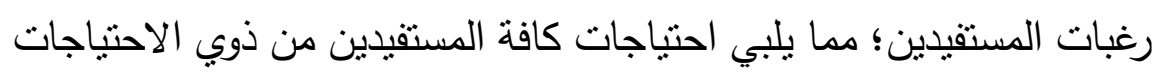

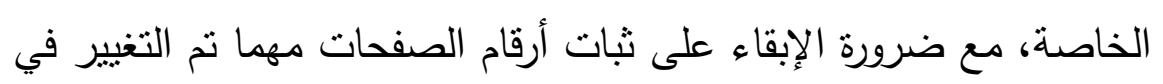
حجم الخط أو اتجاه الكتابة. 7. توافر إثارات مرجعية داخل الصفحة الواحدة كإحالة بين الكلمات المرادفة أو ذات العلاقة. V.توافر روابط تربط بعض الكلمات أو الفقرات بمواقع أخرى على الوبب، لعرفة 
تنمية مهارات تصميم القصة الرقمية باستخدام الكتاب الإلكتروني وعلاقتها بمستوي طموح معلمي المرحلة الابتدائية

تفاصيل إضافية حول هذه المصطلحات أو الفقرات. ^.توافر روابط للربط بين المصطلحات و ملحق الكتاب، تقيد في معرفة معنى هـى المصطلح ثم العودة إلى المصطلح في النص مرة أخرى. 9 ـ نوافر قاموس ناطق يفيد في عرض معنى المصطلحات المراد معرفة معناها، إضافة إلى نطقها النطق الصحيح، وهذه المزبة تقيد من بتحدث بـثن بلغة مختلفة عن لغة الكتاب، أو من لديهم صعوبة في التحدث. • 1. توافر روابط بقائمة المراجع لسهولة الوصول للمرجع المطلوب والعودة بسرعة إلى النص. ا1 . يمكن استغلال عناصر الوسائط المتعددة مثل الفيديو والتسجيل الصوتي، والعناصر التفاعلية في شكل تجارب واختبارات، وطرق الاتصال غير المتاحة في الوسيط الورقي، ولابد من توافر أيقونات داخل النص توضح مكان النص والرسومات والصوت وغيرها من الوسائط المتعددة. ب ا. يمكن للمستفيدين التعديل في نص الكتاب طبقًا لرغباتهم الشخصية، حيث يمكن للقارئ تغيير بعض السمات، منل نمط الخط وحجمه ولونه، كما يجب إتاحة إمكانية حفظ الثكل المفضل لهم للاستخدام فيما بعد، وإضافة لهية ملاحظات في الهوامش ووضع علامات التوقف. rا ـ إضافة روابط بالكتب ذات العلاقة. ع ا ـ تضمين روابط بصفحات الكتب المترجمة للكتب الحالية. 1 1 . تضمين روابط بمقالات وآراء صحفية حول الكتاب. ( الصعويات التي تواجه نشر الكتاب الإكتروني: (1/1)

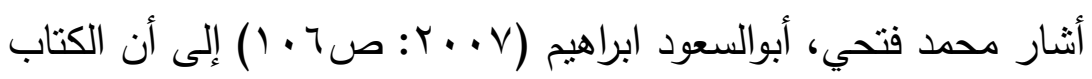

$$
\text { الإلكتروني يواجه صعوبات عدة، أهمها: }
$$

ا ـ الكتب الإلكترونية المتاحة الآن قليلة العدد إذا قيست بالكتب المطبوعة. r. أن الكتب الإكترونية في حاجة إلى جهاز قارئ أو وسيط بيساعد علي الإنه 
تنمية مهارات تصيميم القصة الرقمية باستخدام الكتاب الإلكتروني وعلاقتها بمستوي طموح معلمي المرحلة الابتدائية

استخدامه والاستفادة منه وهناك بعض المشكلات التي تحدث بهذا الوسيط.

r. أن التكلفة عالية إلى حد ما بما يتعلق بالاختزان أو الاسترجاع للمعلومات.

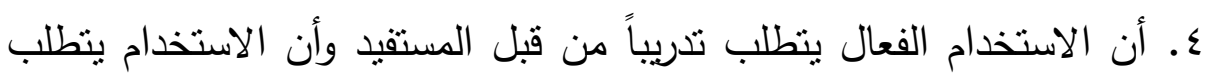

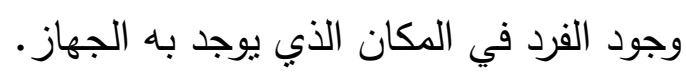

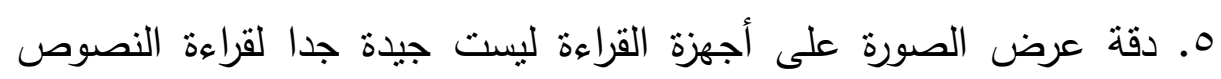

$$
\text { الطويلة. }
$$

جـ قلة العناوين المتاحة: حتي هذا الوقت هناك القليل من العناوين المتاحة

$$
\text { الكترونيا خاصة المجاني منها. }
$$

V. عدم توفر أجهزة القراءة على نطاق واسع في كثير من الدول، وخاصة

$$
\text { العربية. }
$$

^. النظم المعقدة: فبعض الكتب الإلكترونية قد تكون ذات نظم تشغيل معقدة

$$
\text { لحد ما. }
$$

9 ـ ليس هناك حتى الآن تتاغم أو توافق بين البرمجيات والتجهيزات المادية

المختلفة.

• 11 ا ـ حقوق النشر والتوزيع محدودة بالنسبة للاوريات الإكترونية.

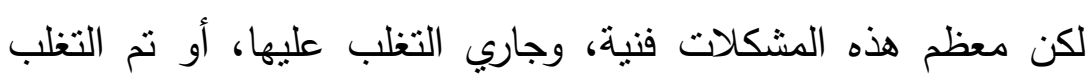

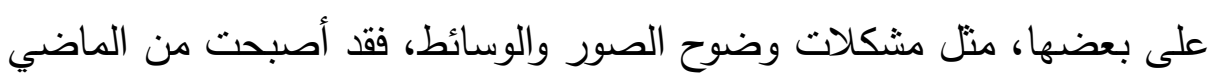
في كثثر من الأجهزة المتخصصة في قراءة الكتب الإكترونية، أما بقية الصعوبات، وقلة العناوين المتاحة، وخاصة المجاني منها، فإن الوقت كفيل بالتخلص من هذه العيوب مع اتساع استخدام الكتب الإلكترونية، وتوسع انتشارها في المدارس والجامعات، مع الدخول إلى منظومات المدارس الذكية والتعليم الجامعي الإلكتروني، وما يفرضه من ضرورة تخطي مشكلات وعقبات استخدام الكتب الإكترونية، وتسهيل إتاحتها بطرق وأساليب متعددة والتخلص من عيوبها، 
تنمية مهارات تصيميم القصة الرقمية باستخدام الكتاب الإلكتروني وعلاقتها بمستوي طموح معلمي المرحلة الابتدائية

وتحسين جودتها، وتسهيل قراءتها بكل الصيغ على كافة الأجهزة.

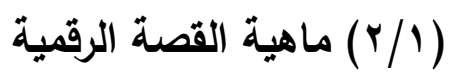

القصة الرقمية هي قصة أُنتجت وحفظت ونشرت باستخدام الوسائط

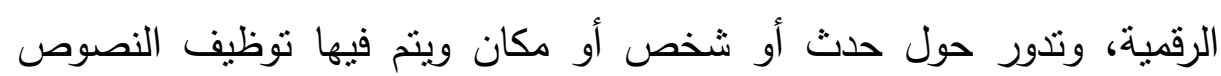

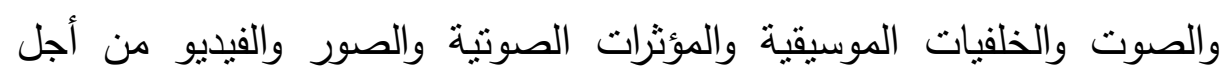

تصميم قصة تعليمية.

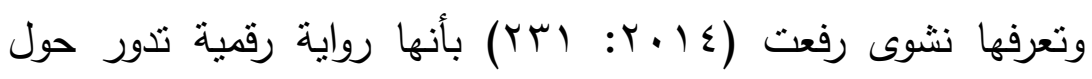

شخص أو حدث ويمكن أن تكون حقيقية أو خيالية ويتم فيها دمج النصوص بـانه

والصور والرسوم والأصوات.

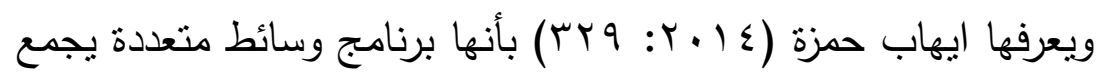

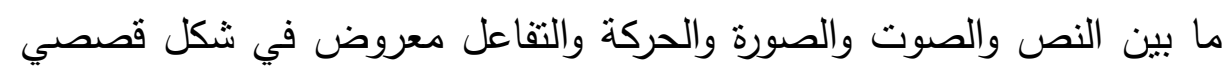
بغرض دعم عمليتي التعليم والتعلم.

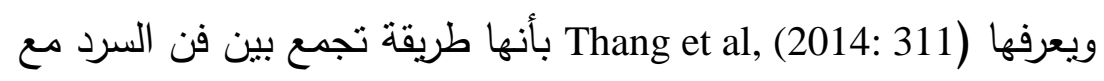

مجموعة منتوعة من ملفات الصوت والفيديو والصور متعددة الوسائط.

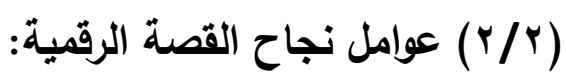

هناك عوامل يمكن أن تسهم في نجاح القصة الرقمية عند استخدامها في الريا

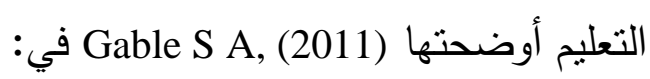

ا الكاريكاتير البصري: وهذا يعني استخدام صور كاريكاتيرية نساعد في نقل

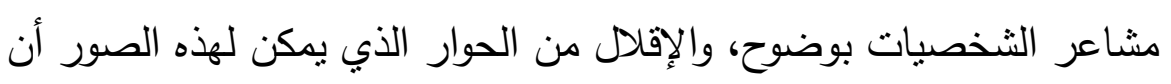

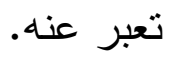

r.جدول زمني تفاعلي: عندما تحكي قصة من منظور واحد يجب أن ينسق الجدول الزمني لسلسلة الأحداث ونتائجها بصورة تفاعلية تجذب اهنبام المتعلمين بالصور الجذابة التي تتقل القصة إلى الأمام.

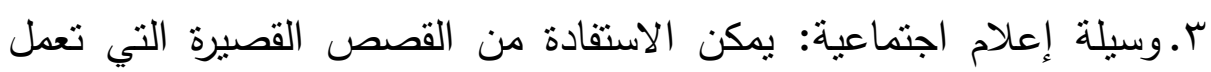


تنمية مهارات تصميم القصة الرقمية باستخدام الكتاب الإلكتروني وعلاقتها بمستوي طموح معلمي المرحلة الابتدائية

بشكل جيد وتعد مصدر إلهام لمناقثة موضوع تعليمي محدد، كما يمكن للتعليم الإكتروني تشجيع المتعلمين على مشاركة قصصهم المرتبطة بموضوع الدرس لاستخلاص النقاط الرئيسة للموضوع المطلوب تعلمه.

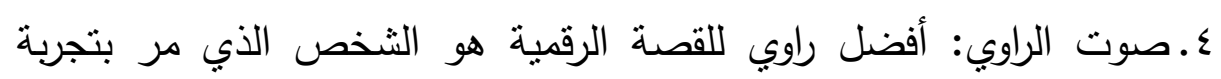

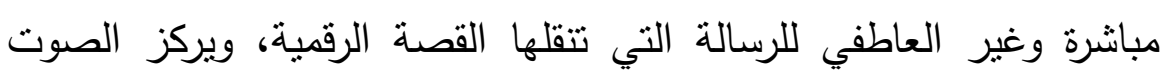

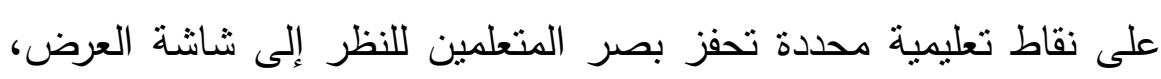
ووجود نصوص على شاشة العرض اختباري حسب الحاجة إليها، والخبراء يميلون إلى الموافقة على أن الراوي الذي يقراً نصاً من شريحة هو في الواقع يضر المتعلم أكثز مما بنفعه.

هـ الفيديو: يمكن استخدام أفلام الفيديو في القصة الرقمية لإعطائها لمسة إنسانية، والراوي في هذه الأفلام يشترط أن يتماشى صوته مع لقطات الفيديو .

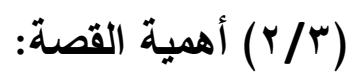

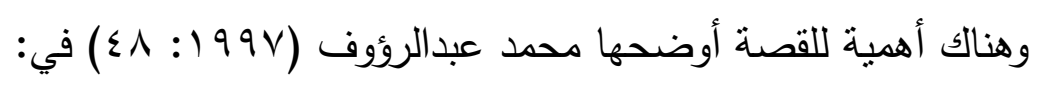

ا.تتمية قدراتهم العقلية: القصة تتميز بقدرة فائقة علي جذب انتباه العقل وتتويقه واثارة خياله، ويمكن عن طريقها تتمية القدرة على التخيل والتذكر هيله والانتباه بالربط بين أحداث القصة وتذكر الأحداث والثخصيات وإدراك فراك الأفكار واستتناج ما قد يحدث بعد ذلك وتوقعه، كل هذه الامور من المككن تتميتها عن طريق القصة التي تقدم للأطفال.

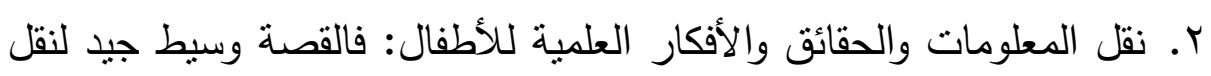
المعلومات والحقائق والأفكار بطريقة مشوقة وجذابة ومحببة للأطفال بشرط والفية

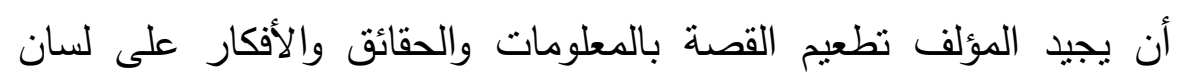
الثخصيات وعن طريق الأحداث المثثرة في القصة ويمكن اعداد المناهج الدراسية في شكل قصص تتقل للأطفال الحقائق والمعلومات بأسلوب قصصي سهل محبب لهم.

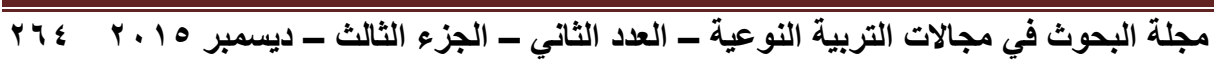


تنمية مهارات تصيميم القصة الرقمية باستخدام الكتاب الإلكتروني وعلاقتها بمستوي طموح معلمي المرحلة الابتدائية

r.تتمية ميل الطفل للقراءة: فالقراءة عملية تتطلب كثيرا من الجهد والمهارة،

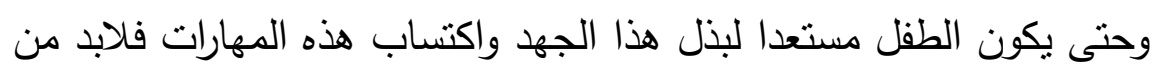
إنشاء علاقة حب بينه وبين الكتاب، والقصة تحقق ذللك. ع. السمو بأرواح الأطفال وتهذيب أخلاقهم: تسهم القصة في السمو بأرواح

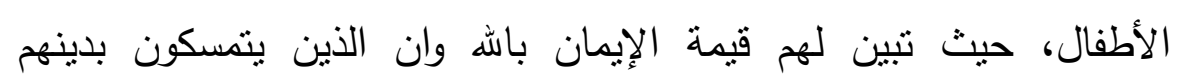

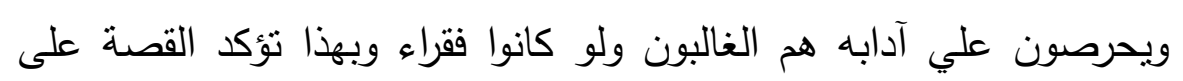
أهمية الجانب المعنوي الروحي ودور تقوم به القصة التي توافر فيها هذا الجانب وتراعي الجانب القيمي والروحي فهي ليست مستودع معارف لهابه ومعلومات بل لابد من تأكيدها على الجانب الاخلاقي القيمي الروحي.

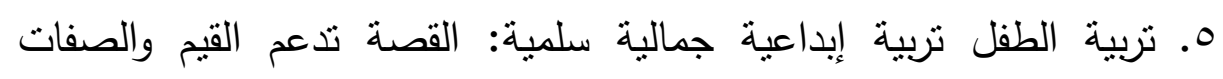
اللازمة لعمليات التفكير الابتكاري والابداعي مثل دقة الملاحظة والصبر والمثابرة والتفكير الجاد المستمر وتتمية الخيال والتفكير الناقد كما تقدم سير العلماء والمخترعين واهل الابداع ليتخذ الأطفال من حياتهم وسيرهم وتصرفاتهم نماذج وامنتة يحتذي بها. 7.تتمية مهارات لغة الطفل: ان للقصة اثرا تربويا في الطفل يتمنل في انها

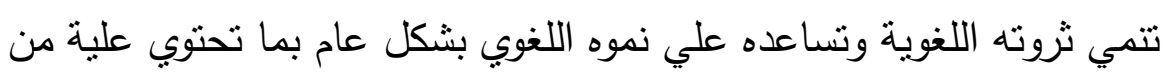
مفردات جديدة وعبارات جيدة، وتدرب التلاميذ بصورة فعالة علي التعبير بنوعية الثفهي والتحريري، وترقي اسلوب التلميذ الكتابي والكلامي، وتعطي

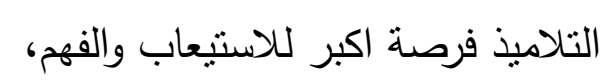

V.تتمية الميول القرائية لدي الأطفال: القصة تجذب لبعاب الطفل لقراءتها حيث تجعل

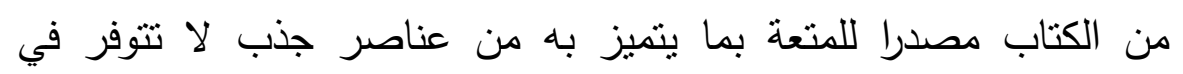
الكتاب العادي ومع الوقت يألف الطفل الكتاب ويتكون لديه ميل الي القراءة عموما بعد التدريب علي قراءة القصص. 
تنمية مهارات تصيميم القصة الرقمية باستخدام الكتاب الإلكتروني وعلاقتها بمستوي طموح معلمي المرحلة الابتدائية

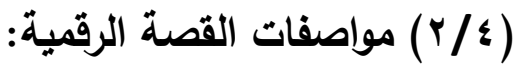

للقصص الرقمية مواصفات لابد أن تتميز بها وهي كما ذكرتها هديل

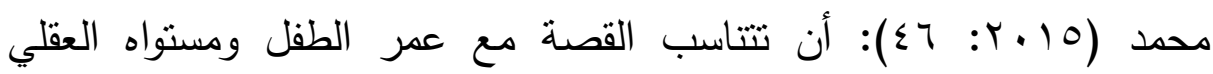
واللغوي، وأن تزود الأطفال بالخبرات والمعارف الجديدة، ويجب أن نتتهي نهاية سعيدة ومبهجة، وأن تكون سهلة النشغيل والاستخدام من قبل الطفل.

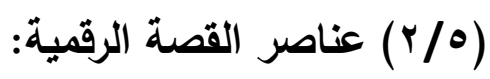

كان التركيز مساعدة رواة القصص أن يجدوا القصة التي يريدون، ومن ثم مساعدتهم على تحديد تلاك القصة في شكل مكتوب، وبالنسبة لكثير من رواة القصص أثنتت عملية التوضيح هذه أنها عملية تجربة تحويلية، ويجب زيادة صقل هذه العملية وتطور هذا النوع، ليجعل القصة الرقمية قصة جيدة، وهناك

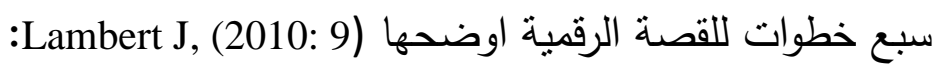

ا ـالرؤية: والمقصود هو مساعدة رواة القصص أن يجدوا ويوضحوا ما قصصهم حول، وفي كثير من الأحيان ابدأ بالسؤال: "ما هي القصة

$$
\text { التي تريد قولها؟" ومن ثم متابعة. }
$$

r.امتلاك المشاعر: والمقصود هو مساعدة رواة القصص في النظر في

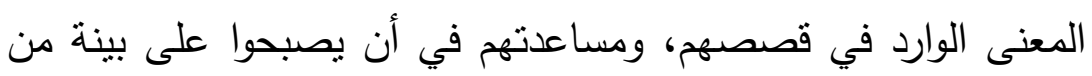

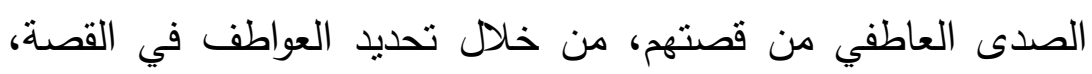
وتحديد تلك العواطف التي يرغبون في تضمينها في القصة ونقلها إلى

$$
\text { جمهورهم. }
$$

r.اللحظة المناسبة: العثور على وتوضيح الرؤية والعواطف من القصة يمكن أن يكون الأكثر تحديا في الجزء الخاص من القصة، ويصبح المعني واضحا للراوي حول قصتهم، والمقصود هو مساعدة رواة القصص قول قصتهم كقصة من خلال تحديد لحظة واحدة يمكن لهن استخدامها لتوضيح رؤيتها من خلال طرح سلسلة من الأسئلة: "ما كانت 
تنمية مهارات تصيميم القصة الرقمية باستخدام الكتاب الإلكتروني وعلاقتها بمستوي طموح معلمي المرحلة الابتدائية

اللحظة عندما تغيرت الأمور؟ هل كنت على علم بذلك في ذلك الوقت؟

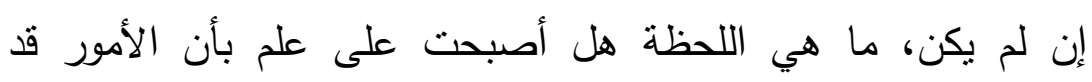

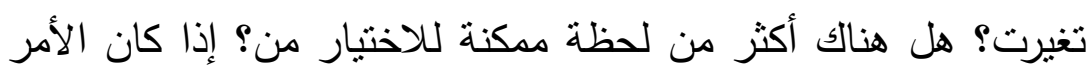

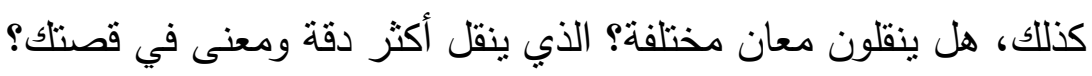
هل يمكن أن تصف لحظة بالتفصيل؟ وذلك للمساعدة في تحديد كيف سيتم استخدامها لشكل القصة. ع.روئة القصة: العثور على لحظة التغيير في القصة ووصفه في مشهد هو نقطة انطلاق لإخبار القصة كقصة، ولمساعدة رواة القصص وتبادل قصصهم في شكل قصة رقمية، يجب النظر في كيفية استخدام المرئيات والصوت وجلب الأثياء إلى الحياة للجمهور ، وهنالك العديد من الخيارات التي تأتي جنبا إلى جنب مع تصميم كيف يمكن للجمهور "رؤية" و "سماع" القصة الرقمية، من خلال مناقثة الخيارات البصرية في وقت مبكر من عملية تصور القصة والنظر في كيفية استخدام الصور التي سوف تشكل قصتهم، ووصف الصور التي تتبادر إلى الذهن، فهم ما تلكك الصور، والعثور على أو إنشاء تلاك الصور، ومن ثم تحديد كيفية أفضل طريقة لاستخدامها لنقل المعنى المقصود. ه. سماع القصة: مساعدة المرئيات في تقديم قصة إلى الحياة، فالصوت لاته المسجل من الحكاية ورواية القصة هو ما يجعل ما نسميه "القصة الرقمية" قصة رقمية، وليس فيديو موسيقي أو عرض الثرائح، ومن هذه النقطة في هذه العملية، يتم التعرف على لهجة عاطفية من القصة، والصوت هو واحد من أفضل الطرق لنقل هذه النغمة، ومن خلال الطريقة التي يتم بها تتفيذ الصوت، والكلمات التي يتم التحدث بها، والصوت المحيط والموسيقى التي تعمل مع السرد، وعند النظر في لهي لهي استخدام الصوت، يمكن طرح الاسئلة: "ما بعد التسجيل الصوتي 
تنمية مهارات تصيميم القصة الرقمية باستخدام الكتاب الإلكتروني وعلاقتها بمستوي طموح معلمي المرحلة الابتدائية

المسجل، هل سيتم تعزيز القصة والمشاهد في داخلها واستخدام طبقات إضافية من الصوت؟ هل استخدام الصوت المحيط أو الموسيقى يسلط وله الضوء علي نقطة التحول في القصةٌ؟ هُ 7.تجميع القصة: تجميع القصة من خلال نشر الملاحظات والصور

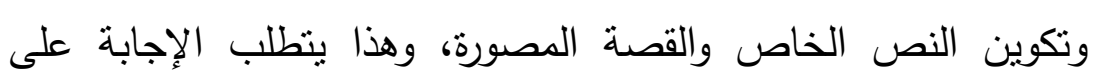
سؤالين: كيف يمكنك هيكلة القصةٌ وضمن هذا الهيكل، وكيف هي

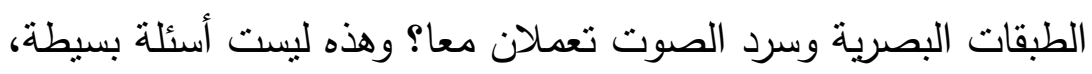
فعند النظر في مسألة الهيكل، فان تحديد لحظة التغيير، في أي نقطة في القصة سوف تظهر؟ هل هي في البداية، منتصف، نهاية، أو تقسيمها في نقاط مختلفة في جميع أنحاء القصة؟ أم أنها القصة بأكمها؟ هل هناك تفاصيل أو مشاهد أخرى ضرورية لتوفير سياق لحظة التغيير؟ وفي أي ترتيب سوف تتسلسل كل هذه المعلومات؟.

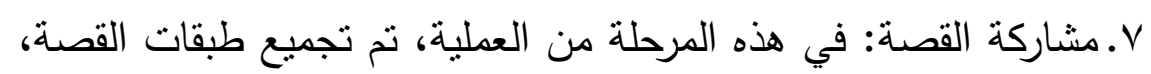
والبحث وتوضيح الروية، وخلق القصة الرقمية، والتفهم الذاتي للراوي، وقد تتطور القصة والرؤية التي تتقل طوال العملية، ولذلك، فمن المهح أن أخذ جزء من الوقت لإعادة النظر في السياق الذي تم وصف القصة وله في البداية من أجل تحديد المعلومات ذات الصلة لنتمل عندما يتم

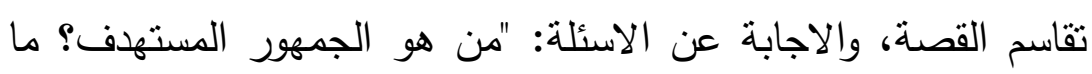
هو الهدف من انشاء القصة؟ هل وضح الهدف خلال عملية انثاء القصة؟ كيفية عرض القصة الرقمية؟ وما هي حياة القصة او مصيرها

$$
\text { بعد اكتمالها؟ }
$$

وترى (Gable S A, (2011 أن هناك عناصر ضرورية يجب على كاتب القصة الرقمية تحديدها أثناء كتابته لها وهي كالتالي: 1. الثخصيات: يجب تحديد شخصيات القصة الرقمية سواء الرئيسة أو 
تنمية مهارات تصيميم القصة الرقمية باستخدام الكتاب الإلكتروني وعلاقتها بمستوي طموح معلمي المرحلة الابتدائية

\section{الثنانوية.}

r. العقدة: عبارة عن مشكلة القصة الرقمية أو الهدف من كتابة القصة وما سيكتسبه التلميذ من متابعة القصة الرقمية. r. الأحداث والإجراءات: عادة تبدأ القصة الرقمية بحدث يثير التلميذ

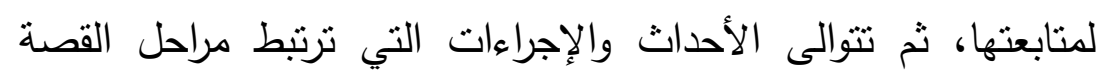

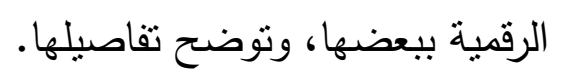

ع. الذروة: عبارة عن حل المشكلة، أو الدروس المستفادة من رواية القصة

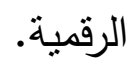

ه. نهاية القصة الرقمية (الخاتمة): عادة ما تتنهي القصة الرقمية بييان

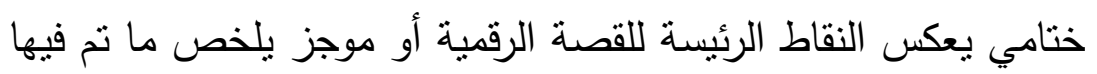

$$
\text { من أحداث. }
$$

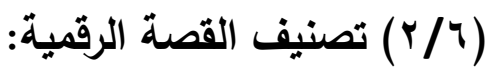

McLellan, H, هناك تصنيفا للقصة الرقمية حسب الاستخدام اوردته

$$
\text { (2006: 65-79) }
$$

القصة الثخصية: لقد اعتاد الناس على مر العصور أن تكون لهم قصص

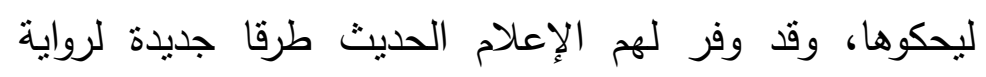

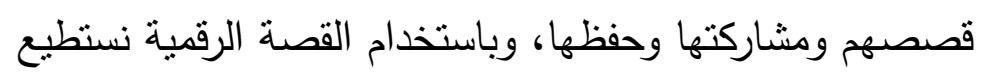

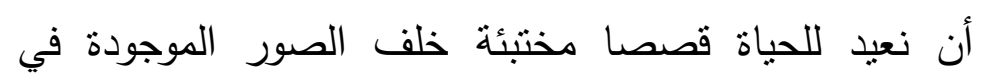

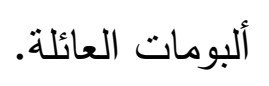

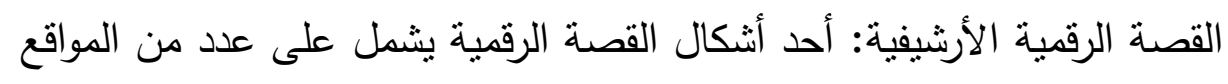

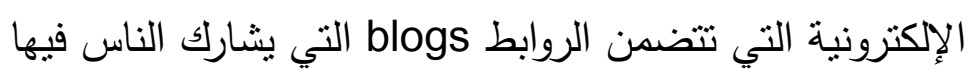

$$
\text { قصصهم في العديد من الأفكار والموضوعات. }
$$

القصة التعليمية: أدرك عديد من النزبويين مستقبل القصة الرقمية، حيث إنها

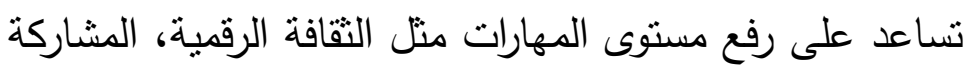

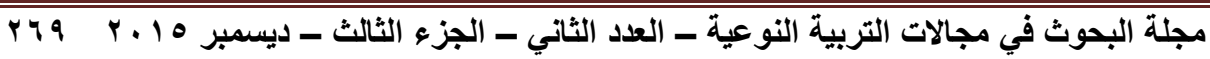


تنمية مهارات تصيميم القصة الرقمية باستخدام الكتاب الإلكتروني وعلاقتها بمستوي طموح معلمي المرحلة الابتدائية

واتقان التكنولوجيا، والتي تعد من المهارات المهمة في العصر

$$
\text { الحديث. }
$$

وهناك تصنيف للقصة الرقمية فيما بخص أنماط تقديم المحتوي يحددها

في: Ohler, J, (2006: 44-47)

الشكل المسموع للقصة الرقمية: حيث يؤكد أن الثكل المسموع أقدم أثكال القصة الرقمية، وبالرغم من تقدم التكنولوجيا إلا أن الثكل الثل

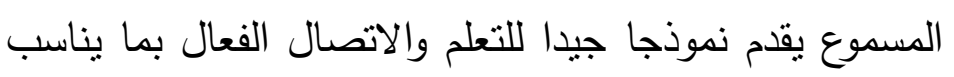
المجتمعات التعليمية، حيث إنه بساهم في تكوين الخبرات

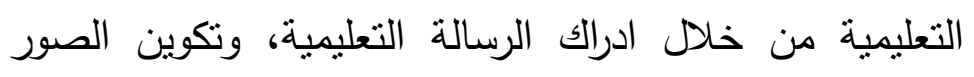
الذهنية من الكلمات التي يتم سماعها في مضمون القصة الرقمية، وبذلك يصبح التلميذ شريكا إيجابيا في تكوين المعلومة الواردة بالقصة.

الثكل المرئي للقصة الرقمية: يوفر هذا الثكل الصور والرسوم الثابتة

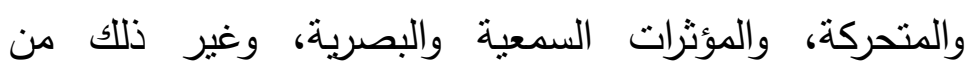
العناصر التي تجذب انتباه المتعلمين، ونتيح فرصا متتوعة في ولئي

$$
\text { تقدي المحتوي. }
$$

الثكل المكتوب للقصة الرقمية: إن هذا الثكل يمثل أداة التعلم الرئيسة للمتعلمين

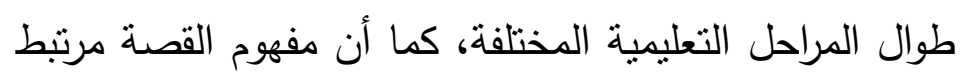
دائما بالثكل المكتوب، وترجع أهمية هذا الثكل في كونه يساهم بشكل فعال في تتمية قدرة المتعلمين على التقكير ، واستخلاص المعنى الضمني للنص المكتوب مما يجذب المتعلمين لمحتوي

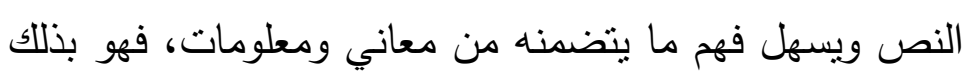
لا يقل أهمية عن الثكل المسموع والمرئي. 
تنمية مهارات تصيميم القصة الرقمية باستخدام الكتاب الإلكتروني وعلاقتها بمستوي طموح معلمي المرحلة الابتدائية

( معايير تقييم القصة الرقمية: (

أوضح Lambert J, (2013 أنه يفضل في القصص الرقمية أن:

ا. تشتمل على عدد مناسب من الصور، والأصوات، ولقطات الفيديو،

والنصوص، والرسوم المتحركة، وينبغي أن تتكامل هذه الوسائط مع فئ

بعضها وبشكل مناسب في تحقيق الهدف من القصة.

r. يتوافر بها قدر من التوافق وإحساس المشاهد بالانسجام بين المكونات

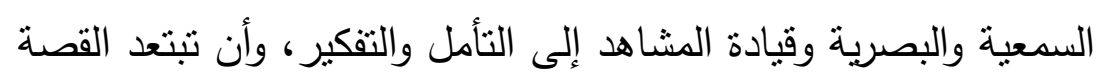

عن النغمات الصوتية السربعة والعرض الخاطف للصور •

r. يتم فيها اختيار الخلفيات الموسيقية المناسبة، والبعد عن نزامن التعليق

الصوتي مع الخلفيات الموسيقية الغنائية، التي قد تشتت انتباه المشاهد،

وينبغي إيلاء اهتمام للخلفيات الموسيقية التي تثير مشاعر المشاهد

وعواطفه ونحو موضوع القصة.

ع. يتم فيها اختيار الحركة التي تجذب تركيز المشاهد لأحداث القصة

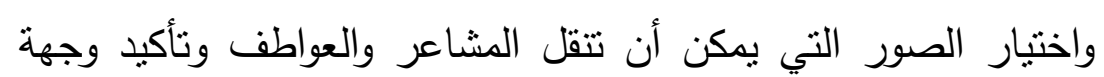

النظر للمشاهد.

ه. يكون هناك تتاغم بين التعليق الصوتي والصور والخلفية الموسيقية. 7. تتضمن إيقاعاً سريعاً في سرد الأحداث التي تتطلب إنارئ إنارة عاطفة المشاهد، وأن تتضمن إيقاعاً بطيئاً أو عادياً في سرد الأحداث التي تتطلب من المشاهد الاسترخاء والتأمل.

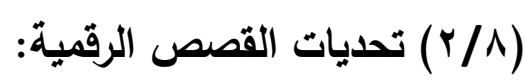

يثير Frazel M, (2010: 109-122) على مجموعة من التحديات التي

تواجه استخدام القصص الرقمية في العملية التعليمية وتتمنت فيما يأتي:

ا. إن القصص الرقمية فيها انتفاع التكنولوجيا، ومن ثم فهي تحتاج إلى

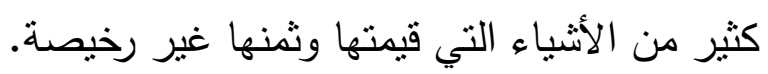

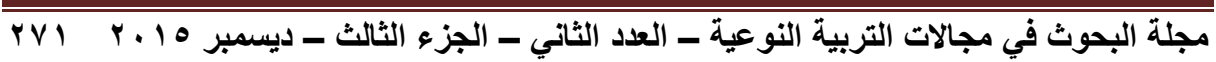


تنمية مهارات تصيميم القصة الرقمية باستخدام الكتاب الإلكتروني وعلاقتها بمستوي طموح معلمي المرحلة الابتدائية

r. التكنولوجيا تتطلب كفاءة إتقانها، ومن المؤسف أن كثير من مدرسي اللغة العربية لا يمنلك كفاءة إتقان التكنولوجيا. r. تستغرق القصص الرقمية الوقت الطويل في إعدادها، وتجهيزها لتطبيقها. ع. يجد المعلمون صعوبة في إعطاء التوجيهات للطلاب، لأن استخدام القصص الرقمية جديد. ه. لا يمكن استخدام القصص الرقمية في جميع المواد.

(r/1) ماهية مستوي الطموح

يعد الطموح من السمات الهامة لأنه من العوامل المهمة المؤثرة بما

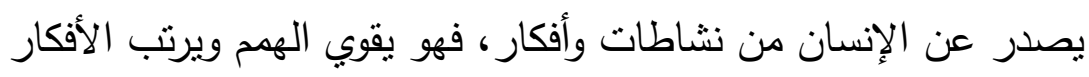

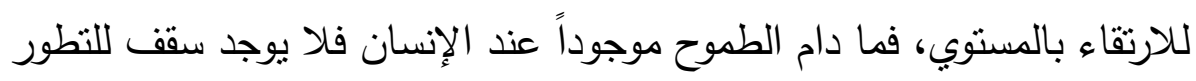
العلمي والحضاري.

والطموح تصور قبلي، أما مستوى الطموح فهو نتاج بعدي لقياس كمي ويجب الإشارة إلى أن الفرد لن يكون لديه مستوى طموح بالنسبة لجميع الأعمال

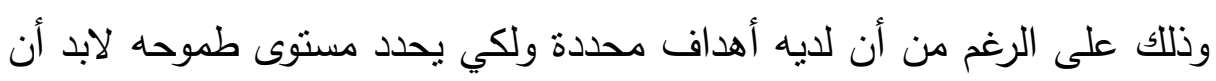

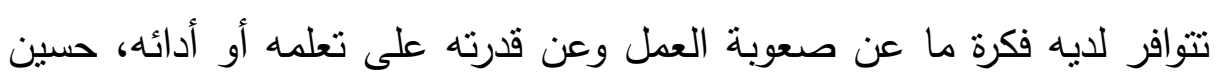

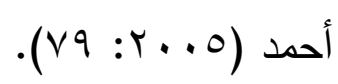

والطموح بعتمد بدرجة كبيرة على المقدرة فربما نرغب أن نكون شعراء أو أو علماء مشهورين ولكن إذا ما كانت إمكانياتتا قليلة فإننا نتخلى عن هذا الطموح مبكراً وغالباً ما نترك هذه الأهداف المستحيلة دون مبالاة وذلك لأنتا لسنا

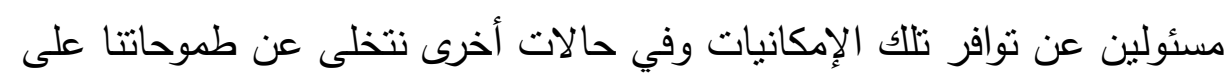
الرغم من ميولنا الكبيرة وهذا يعني أنه لا يكفي أن يكون لدينا ميل أو رغبة في لإني

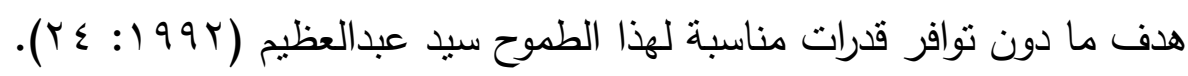

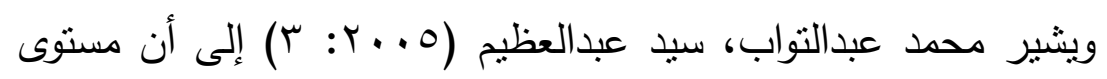


تنمية مهارات تصيميم القصة الرقمية باستخدام الكتاب الإلكتروني وعلاقتها بمستوي طموح معلمي المرحلة الابتدائية

الطموح هو سمة ثابتة نسبياً تشير إلى أن الثخص الطموح هو الذي ينسم بالتفاؤل والمقدرة على وضع الأهداف وتقبل كل ما هو جديد وتحمل الفنشل والإحباط.

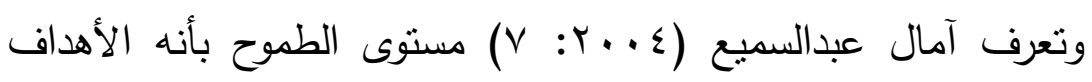

التي يضعها الفرد لذاته في مجالات تعليمية أو مهنية أو أسرية أو اقتصادية بانه

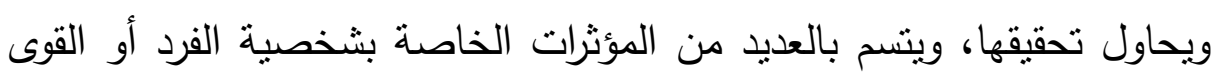
البيئية المحيطة به وإذا نتاسب مستوى الطموح مع إمكانية الفرد وقدراته الحالية والمتوقعة كانت السوية وإذا لم يتتاسب معها ظهرت التفككية والاضطراب ودائماً الفرد يحاول تخطي العقبات التي تحول دون تحقيق أهدافه أو تعرقلها وأحياناً

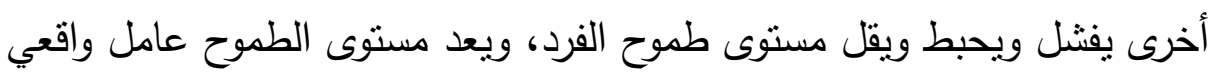
للأداء والتفوق كما يعد من خصائص الثخص الصلبة التي تتحمل الضغوط وتتصف بالتحدي والضبط والالتزام.

( ) خصائص الشخص الطموح:

من الخصائص التي يمتاز بها الثخص الطموح عن غيره:

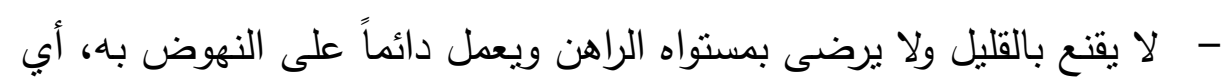
لا يرى أن وضعه الحاضر أحسن ما يمكن أن يصل إليه.

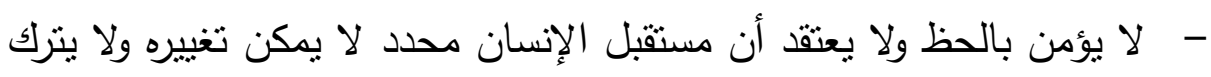

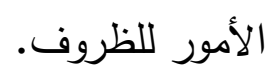
- - لا يخثى المغامرة أو المنافسة أو المسؤولية أو الفنشل. - ل الا يجزع إن لم تظهر نتائج جهوده سريعاً. - - النظرة المتفائلة إلى الحياة والاتجاه نحو التفوق والميل نحو الكفاح وتحديد الأهداف والخطة وتحمل المسؤولية والاعتماد على النفس والمثابرة. نظيمة

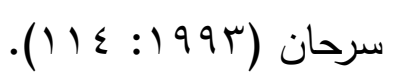

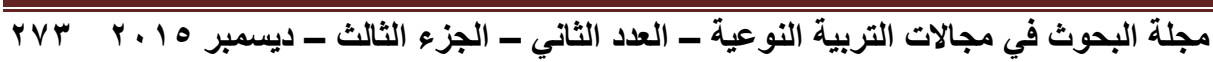


تنمية مهارات تصيميم القصة الرقمية باستخدام الكتاب الإلكتروني وعلاقتها بمستوي طموح معلمي المرحلة الابتدائية

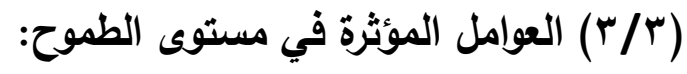

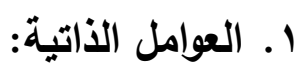

الثواب والعقاب: الثواب "الأثز الذي يتبع الأداء أو الاستجابات، ويؤدي إلى الثعور بالرضا أو الارتياح وتتمثل حالة الرضا والارتياح

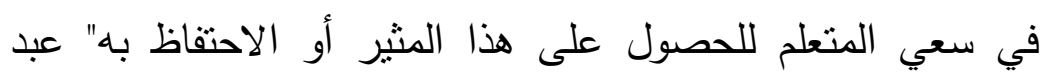

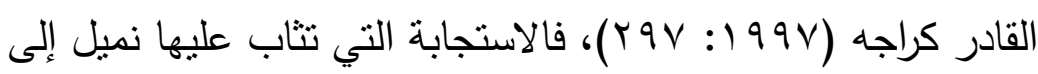
تكرارها لأنها مقبولة للفرد والجماعة ومريحة للشخصية أما الاستجابة التي نعاقب عليها نعمل على تفاديها، لأنها غير مقبولة من طرف ومن ونه الفرد والجماعة ومضرة للشخصية.

خبرات النجاح والفتشل: "النجاح يؤدي عادة إلى رفع مسنوى الطموح، بينما الفثل يؤدي إلى خفض ذلك المستوى، كما أن احتمالات ارتفاع

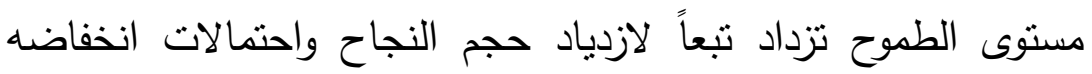
تزداد تبعاً لازدياد حجم الفثل". سهير كامل (999 19: (9 (1) وتوصلت الدراسات إلى أنه كلما كان النجاح كبيراً كلما كبرت نسبة ارتفاع مستوى هُدي

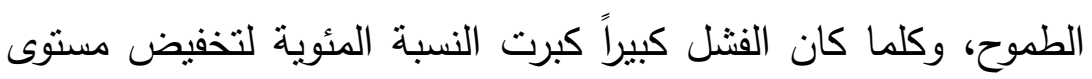

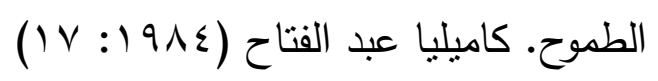
فالتلميذ عندما ينجح ويدرك مقدار نجاحه (مرتفعاً أو متوسطاً أو ضعيفاً)، يدفع به إلى الأمام ويعطيه ثقة أكبر بنفسه، بل يعطيه تعزيزاً

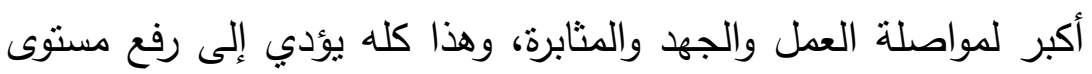

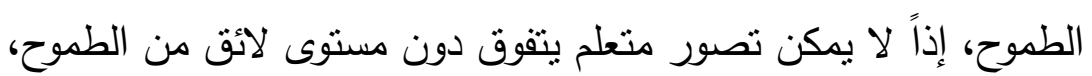

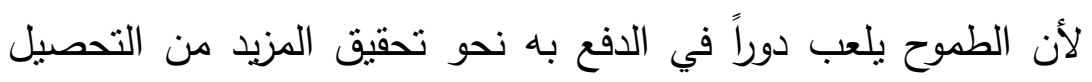

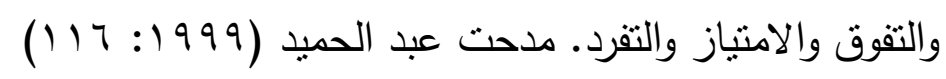
مفهوم الذات: قوة دافعة للسلوك، فإنها تذفع بمستوى الطموح للارتقاء وبالفرد للشعور بكيانه ووجوده، وهذا يكون في حالة الإدراك الإيجابي 
تنمية مهارات تصيميم القصة الرقمية باستخدام الكتاب الإلكتروني وعلاقتها بمستوي طموح معلمي المرحلة الابتدائية

للأات أما إذا كان الإدراك للذات سلبي فإنه لا محالة من انخفاض

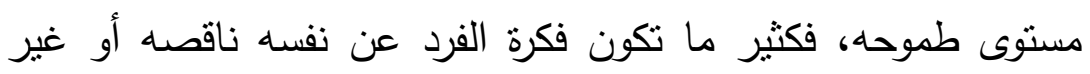

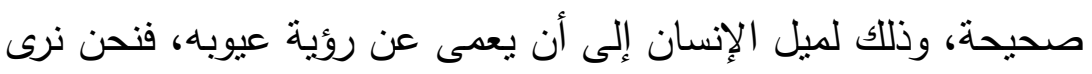

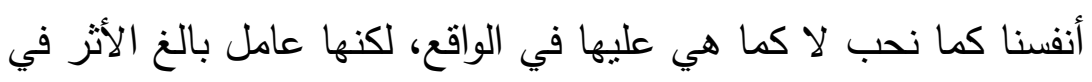

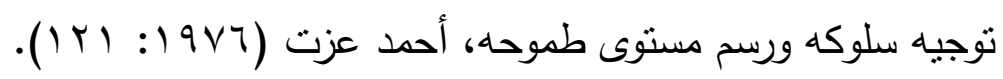

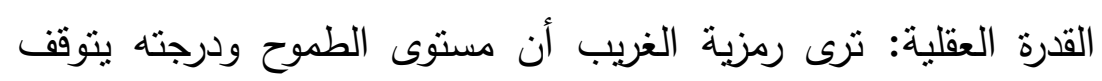
على قدرة الفرد العقلية، فكلما كان الفرد أكثر قدرة كان بمقدوره القيام بتحقيق أهداف ابعد وأكثر صعوبة، ولما كانت قدرة الطفل العقلية تزداد بازدياده في العمر حتى يصل غلى مستوى معين، فإن مستوى طموح الطفل يتغير بتغير عمره الزمني رمزية الغريب ( •99 (19: وبr). التوافق النفسي: الإنسان السوي الثخص الأكثر استبصاراً بذاته وقدراته والعوائق التي تواجهه في تحقيق أهدافه، وأكثر تقبلاً لحدود إمكانياته، وذللك بسبب إدراكه الموضوعي لذاته وللعالم، مما يساعده على وضع

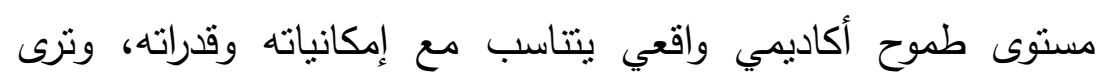
هيرلوك أن المضطربين انفعالياً يميلون إلى وضع مستويات طموح مرتفعة جداً - غير واقعية - في حين أن المتوافقين انفعالياً يضعون الفئن مستويات طموح واقعية تتفق مع إمكانياتهم وقدراتهم، وتبين أيضاً أن الشخص الذي يعاني قلقاً بسيطاً بميل إلى وضع مستويات طموح عالية

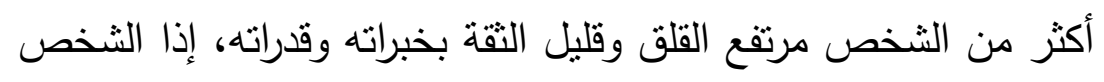
الواثث من نفسه والمنوافق معها يرفع من مستوى طموحاته بعد النجاح ويخفضه بعد الفنش، على عكس غيره من الأثخاص المضطربين، وهذا ما تؤكده العديد من الدراسات الإكلينيكية من أن النواحي الانفعالية

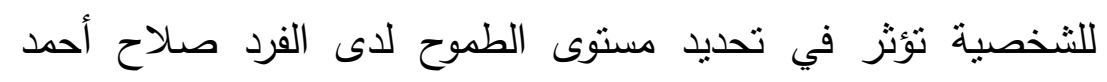

$$
\cdot(1.9: 19 \wedge \varepsilon)
$$

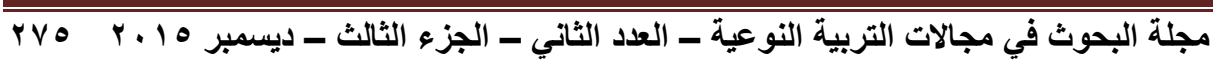


تنمية مهارات تصيميم القصة الرقمية باستخدام الكتاب الإلكتروني وعلاقتها بمستوي طموح معلمي المرحلة الابتدائية

\section{r. العوامل الأسرية:}

التربية الأسرية: تعبر الأسرة الخلية الأولى التي عرفها المجتمع الإنساني

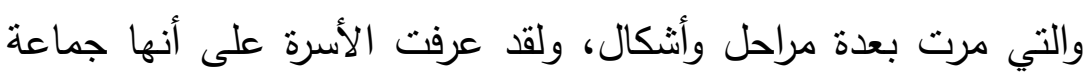

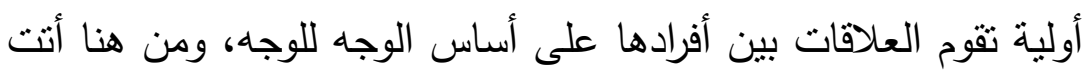

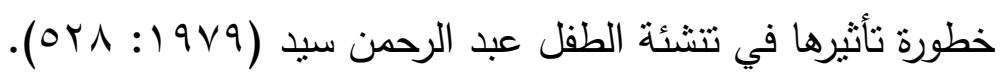

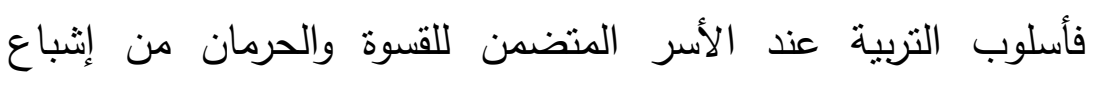

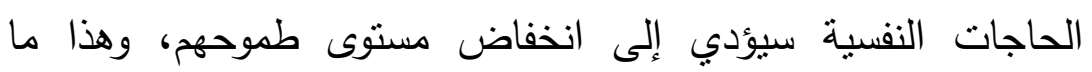
توصلت إليه دراسة صابر حجازي (ع (91) حيث أكدت وجود علاقة إيجابية بين مستوى الطموح وبين اتجاهات الآباء في التتشئة التي تتسم بالتسلط والتدليل المفرط. المستوى الاجتماعي والاقتصادي للأسرة: هناك علاقة ارتباطية بين التوافق النفسي (الثخصي والاجتماعي) ومستوي الطموح، فقد اشارت الدراسات الي ان علاقة مستوي الطموح بالتوافق علاقة وثيقة ودينامية منبادلة فأي تغير في احدهما يتبعه تغير في الاخر كاميليا عبدالفتاح (109:191 1 ) طموح الوالدين أو الأهل: يؤكد جليل وديع (1997 إ: ع V) من أن الآباء في تعاملهم مع أبنائهم يركزون على هذه الأمور ويثيرون ذلك في نفوس الته أبنائهم بالتشجيع والتركيز ويقول في هذا "يكفي الأب مثناً أن يقول لابنه منذ الصغر إنه سيصبح في المستقبل طبيباً، وأن يحبب إليه هذه المهنة

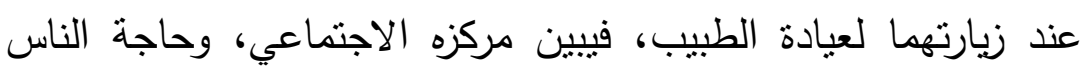
إليه، ويبين له أثناث مكتبه الفخم، ومدخوله ويوضح له كل تبعيات هذه المهنة أو أية مهنة تشابهها، وبكفي ذلك لترتسم في مخيلة الطفل معالم

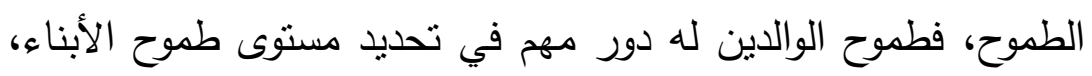

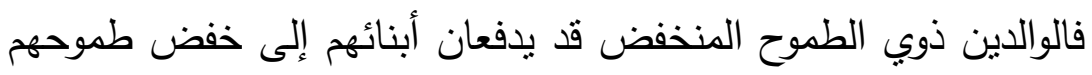


تنمية مهارات تصيميم القصة الرقمية باستخدام الكتاب الإلكتروني وعلاقتها بمستوي طموح معلمي المرحلة الابتدائية

خوفاً من تعرضهم للفشل، وخوفاً من مشاكل هم في غنى عنها.

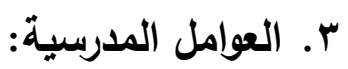

البيئة المدرسة: لتجح المدرسة في تحقيق أهدافها ومهامها لابد لها من تكوين بيئة تعليمية تربوية واسعة المجال لتدريب التلاميذ على ممارسة التفكير والحرية في اختيار ما يرونه مناسباً لهم مما تقع عليه عيونهم من خبرات، وأن لا يجبرونهم فيشعرون بالاغتراب بدل الطموح أمال

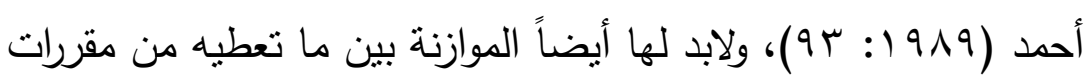

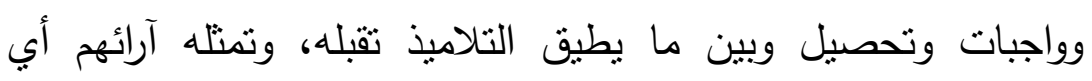
الموازنة بين المقررات والقدرات وبين مستوى التحصيل ومستوى الطموح، فعدم توازن الهدف المنشود مع الوسيلة المؤدية إليه يؤدي إلى الفشل.

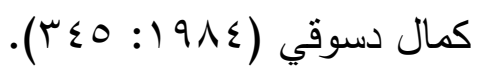

شخصية المدرس: يعد المعلم أحد الثخصيات التي لها تأثير على دلى التلميذ، فهو صاحب التغيير والتشكيل والتأثنر على شخصية المتعلم بما يتصف به من صفات، وبناء على ذلك يتحدد مستوى طموح التلاميذ بين الارتفاع والانخفاض حسب مميزات المعلم أو المدرس، فالمدرس هو النموذج والمصدر الذي يستمد منه الطفل النواحي النقافية والخلفية التي تساعده على أن يسلك سلوكاً سوياً. جماعة الرفاق: مما لا شك فيه أن البيئة المدرسية تعتمد على جماعات بلى لمات

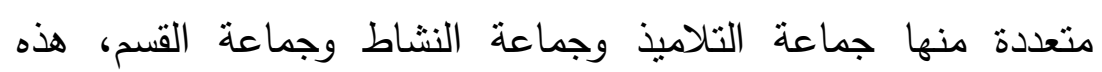
الجماعة التي تؤُثر على سلوك الفرد في عدة جوانب، فهي تؤثر على وجلى تكوين اتجاهات الفرد، وكذلك على أسلوب اتجاهاته للمواقف الاجتماعية المختلفة، كما نؤُثر على درجة طموح الفرد، سلوى عثمان، هناء حافظ (191:1999) 
تنمية مهارات تصيميم القصة الرقمية باستخدام الكتاب الإلكتروني وعلاقتها بمستوي طموح معلمي

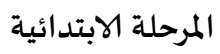

( ) ( النظريات المفسرة لمستوى الطموح:

تعددت النظريات المفسرة لمستوى الطموح ومن هذه النظريات:

\section{:Adler نظرية}

يعد Adler الإنسان كائناً اجتماعياً تحركه دوافع اجتماعياً في الحياة فهو له أهداف في حياته يسعى إلى تحقيقها وقد استخدام Adler عدة مفاهيم منها:

- - الذات الخلاقة: وتعني ذات الفرد التي تدفعه إلى الخلق والابتكار . - الكفاح في سبيل التفوق: وهو أسلوب حياة تتضمن نظرة الفرد للحياة من حيث التفاؤل والنتشاؤم.

- الأهداف النهائية: حيث يفرق الفرد الناضج بين الأهداف النهائية القابلة للتحقيق والأهداف الوهمية والتي لا يضع الفرد فيها اعتباراً لحدود إمكانياته

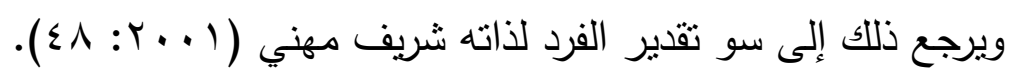
نظرية القيمة الذاتية للهرف:

قدمت Escalona نظرية القيمة الذاتية للهدف وترى أنه على أساس القيمة الذاتية للهدف يتقرر الاختيار ، والاختيار لا يعتمد علي اساس قوة او قيمة

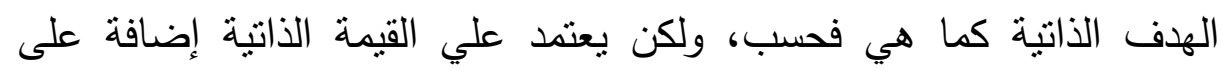
احتمالات النجاح والفثنل المتوقعة وفي عبارة بسيطة فان القيمة الذاتية للنجاح او وزن النجاح تعتبر نتيجة للقيمة نفسها ولاحتمالات النجاح، والفرد يضع توقعاته في حدود منطقة قدراته وتقوم النظرية على ثلاث حقائق هي: - - - هناك ميل لدى الأفراد ليبحثوا عن مستوى طموح مرتفع نسبياً. - كما أن لديهم ميلاً لجعل مستوى الطموح يصل ارتفاعه إلى حدود معينة. - الميل لوضع مستوي الطموح بعيدا جدا عن المنطقة الصعبة جدا والسهلة جدا. وتقول Escalona أن هناك فروقاً كبيرة بين الناس فيما يتعلق بالمبل الذي

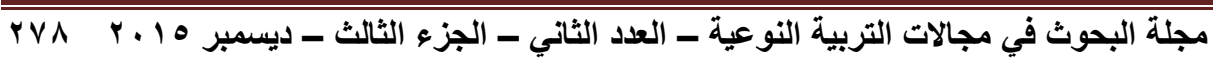


تنمية مهارات تصيميم القصة الرقمية باستخدام الكتاب الإلكتروني وعلاقتها بمستوي طموح معلمي المرحلة الابتدائية

يسيطر عليهم ويتحكم فيهم لتجنب الفشل او للبحث عن النجاح، فبعض الناس يظهرون خوفا شديدا من الفشل فيسيطر عليهم احتمال الفتشل وهذا ينزل من مستوى القيمة الذاتية للهدف وهناك عوامل تقرر الاحتمالات الذاتية للنجاح والفشل في المستقبل أهمها: الخبرة السابقة، بناء هدف النشاط، الرغبة والخوف والتوقع، المقاييس التهاء الرجعية التي تقوم عليها القيمة الذاتية للمستقبل، الواقعية، الاستعداد

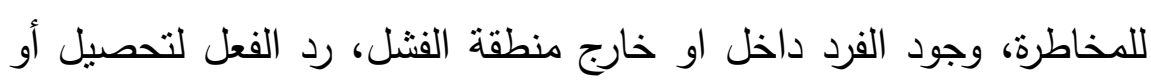

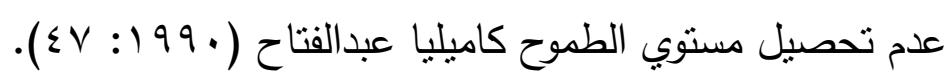

نظرية المجال لـ Keart Levin:

يذكر (صفوت أحمد، 990 1: 1 § ) بأن من أهم دعاة هذه النظرية هو العالم Levin وتسمى نظريته بنظرية المجال فهو يرى أن هناك عدة قوى تعتبر دافعة وتؤثر في مستوى الطموح ومنها: - عامل النضج: فكلما كان الفرد أكثر نضجاً أصبح من السهل عليه تحقيق ومنئ أهداف الطموح لديه وكان أقدر على التفكير في الغايات والوسائل على لهن السواء.

- القدرة العقلية: فكلما كان الفرد يتمتع بقدرة عقلية أعلى كان في استطاعته القيام بتحقيق أهداف أكثر صعوبة.

- - النجاح والفشل: فالنجاح يرفع من مستوى الطموح ويشعر صاحبه بالرضا أما

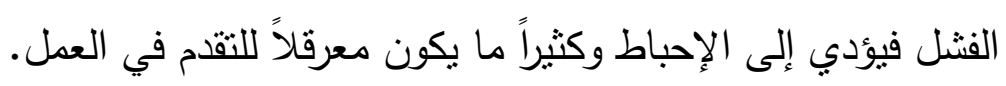
- - نظرة الفرد إلى المستقبل: تؤثر نظرة الفرد إلى المستقبل وما يتوقع أن يحققه فئه

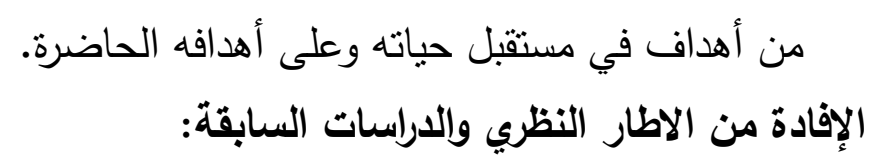
يمكن التعليق على الاطار النظري والدراسات السابقة بذكر جوانب الاستفادة منها كما يلي:

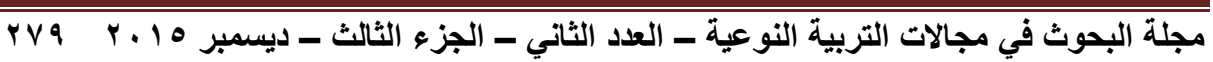


تنمية مهارات تصيميم القصة الرقمية باستخدام الكتاب الإلكتروني وعلاقتها بمستوي طموح معلمي المرحلة الابتدائية

التعريفات: من خلال عرض التعريفات المتعلقة بمتغيرات الدراسة تم التوصل الي التعريفات الاجرائية الخاصة بالدراسة الحالية. المهارات: من خلال عرض الإطار النظري تم التعرف علي أهم المهارات الخاصة بالقصة الرقمية ومستوي الطموح. البرامج: تم التعرف على أهم البرامج المستخدمة في تصميم القصة الرقمية لرمبة واختيار ما يناسب منها. المراجع: التعرف على أهم المصادر التي تستخدم في إعداد الجانب النظري للارراسة الحالية. المنهج: نم الاستفادة من هذه الدراسات في وضع المنهج المناسب لموضوع الدراسة. أدوات الدراسة: تم الاستعانة بهذه الدراسات في إعداد أدوات القياس لمتغيرات الدراسة الحالية. الأساليب الإحصائية: تم الاستفادة من هذه الدراسات في اختيار الأساليب الإحصائية المناسبة. منهجية الدراسة: أولاً ـ منهج الدراسة:

تم استخدام المنهج شبة التجريبي الذي يستخدم لمعرفة فاعلية المتغير المستقل (الكتاب الإلكتروني) على المتغير التابع (مهارة تصميم القصة الرقمية). ثانيا ـ متغيرات الدراسة: المتغير المستقل: الكتاب الإلكتروني. المتغير التابع: مهارة تصميم القصة الرقمية- مستوي الطموح. ثالثا ـ مجتمع وعينة الدراسة: تكون مجتمع الدراسة من مجموعة من معلمي المرحلة الابتدائية وعددهم 
تنمية مهارات تصيميم القصة الرقمية باستخدام الكتاب الإلكتروني وعلاقتها بمستوي طموح معلمي المرحلة الابتدائية

(• • (ع معم نم اختيارهم بطريقة عشوائية وتم معاملتهم كمجموعة واحدة ذات القياس القبلي والبعدي. رابعا ـ التصميم التجريبي للإراسة لئية جلول (1): التصميم التجريبي للاراسة

\begin{tabular}{|c|c|c|c|}
\hline التطبيق البعدي & المعالجة التجريبية & التطبيق القبلي & تصميم الاراسة \\
\hline مقياس مستوى الطموح & الكتاب الإكتروني & بطاقة تقييم المهارة & المجموعة الواحدة \\
\hline
\end{tabular}

بعد الاطلاع علي نماذج التصميم التعليمي العربية والاجنبية المختلفة اقترح الباحث نموذج لتصميم وإنتاج الكتاب الإككتروني تضمن المراحل والخطوات اللازمة لعمليتي التصميم والإنتاج كالآتي:

\section{التشايل}

\section{الاسبثدام|م}

\section{(4)}

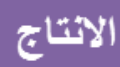

$$
\text { يتكون النموذج من المراحل والخطوات الآتية: }
$$

مرحلة التحليل: شملت الخطوات الآتية:

- تحديد حاجات المتعلمين: وتتضمن تحديد الحاجات التعليمية وهي اكساب 
تنمية مهارات تصميم القصة الرقمية باستخدام الكتاب الإلكتروني وعلاقتها بمستوي طموح معلمي المرحلة الابتدائية

مهارات تصميم القصة الرقمية باستخدام برنامج photo story 3 لدى معلمي

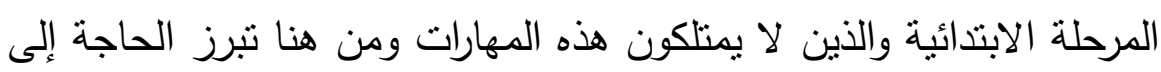

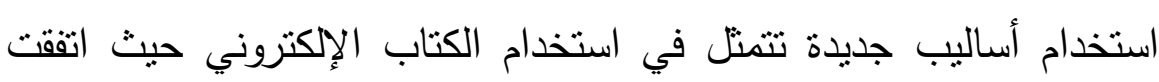
معظم الدراسات على فاعليته في رفع كفاءة عديد من نواتج التعلم.

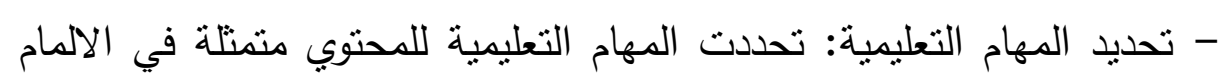
بالجانب المعرفي الخاص بمهارات تصميم القصة الرقمية واكتساب مهارات

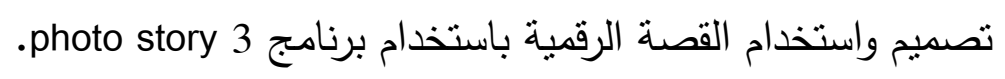
- تحديد خصائص المتعلمين: وتم تحديد خصائص المتعلمين في مجموعة من بن بامين معلمي المرحلة الابتدائية في الفصل الدراسي الأول للعام الدراسي

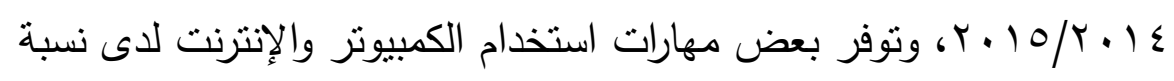
كبيرة منهم، كذلك تجانس العينة من الناحية المعرفية والتكنولوجية. - تحديد السلوك المدخلي: سلوكهم المدخلي لتصميم القصة الرقمية يكاد يكون متساوي حيث انهم لم يتعرضوا لدراسة هذا البرنامج من قبل. - تحديد المتطلبات المادية: متمثلة في توفر معمل كمبيوتر ليطلع من خلاله معلمي المرحلة الابتدائية علي الكتاب الإلكتروني لتدريبهم علي مهارات تصميم القصة الرقمية.

مرحلة التصميم: شملت الخطوات الآتية: - صياغة الأهداف السلوكية: وتتضمن تحديد وصياغة الأهداف إجرائيًا والمتمثلة في: تحديد مفهوم القصة الإلكترونية وأنواعها وفوائدها للمعلم والمتعلم وتصميمها والمفاهيم ذات العلاقة بها، تصميم لوحة الأحداث (تصميم مشاهد القصة ووضع سيناريو التتفيذ للأحداث)، تصميم الثخصيات والمشاهد على أحد برامج تصميم ومعالجة الصور والرسومات، تسجيل الصوت والمؤثرات الصوتية، تركيب وتجميع مشاهد القصة وإضافة الحركة وإخراجها. 
تنمية مهارات تصيميم القصة الرقمية باستخدام الكتاب الإلكتروني وعلاقتها بمستوي طموح معلمي المرحلة الابتدائية

- إختيار المحتوى وتتظيمه: وتتضمن تحديد عناصر المحتوى اللازم لتحقيق

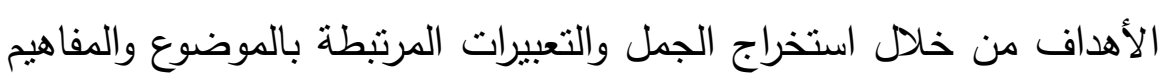

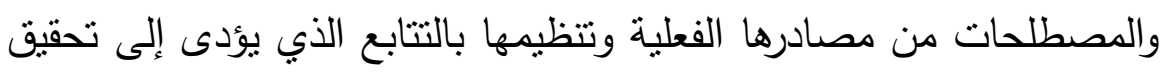
الأهداف وبما يتتاسب وخصائص المتعلمين وأنماط تعلمهم، ونم تقسيم عناصر تحديد المحتوي الي ستة موضوعات رئيسية هي: نتزيل البرنامج، وندان

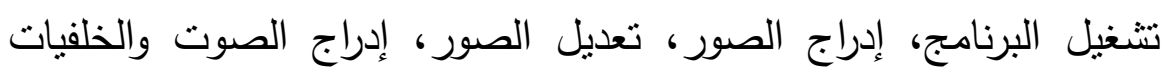
الموسيقية، حفظ البرنامج.

- تحديد الوقت المطلوب للتعلم: يرتبط تتظيم المحتوي وتتابع عرضه، تقسيم هذه الوحدات الي مجموعة من المهارات ومن ثم تحديد الوقت المناسب لكل مهارة، مع مراعاة حرية التلاميذ في تكرار تعلم المهارة. - تصميم الانشطة التعليمية: تم تحديد مهام التعلم وأنشطته التي يجب على على ملى المعلمين إنجازها عند دراستهم للمهارات، ومن تلاك المهام والأنشطة ما يلي: * زيارة بعض المواقع واستعراضها للاستفادة منها في تطبيق مهارات البرنامج، والتي ترتبط ارتباطاً وثيقاً بمهام التعلم أو الأنشطة.

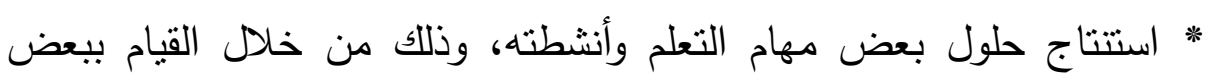
المهام العملية مثل تصميم قصة باستخدام برنامج 3 .photo story. - اختيار الاستراتيجيات التعليمية: وتتمنل في نوع الاستراتيجية التعليمية المستخدمة في تصميم الكتاب الإلكتروني وتتمثل في استراتيجية الثرح

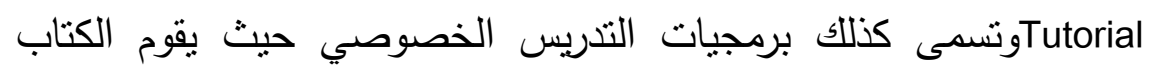
الإكتروني بعرض الأهداف والمادة العلمية الجديدة ويعطي الأمتلة التوضيحية والتدريبات للمتعلم مع متابعة تقدمه في هذه المادة، كما يقوم الكتاب الإلكتروني بدور المعلم الخصوصي في تدريس المصطلحات والمهارات للمتعلم حسب سرعة تعلمه للمهارة. - تصميم بيئة التعلم الإكترونية: البيئة الإلكترونية عبارة عن كتاب الكتروني

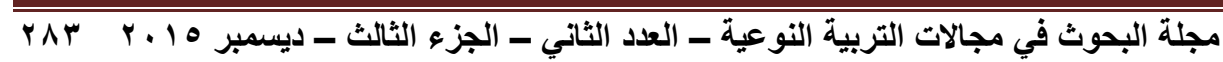


تنمية مهارات تصميم القصة الرقمية باستخدام الكتاب الإكتروني وعلاقتها بمستوي طموح معلمي المرحلة الابتدائية

لشرح مهارات تصميم القصة الرقمية - تقديم التغذية الراجعة: تم تقديم تغذية راجعة من خلال الارتباط التشعبي لبعض المواقع التي توضح تصميم مهارات القصة الرقمية وذلك أثناء تصفح

$$
\text { المعلم للكتاب الإلكتروني. }
$$

مرحلة الإنتاج: شملت الخطوات الآتية:

- التجميع: وتمثلت في تحديد كل الوسائط المطلوبة لإنتاج الكتاب الإلكتروني، سواء كانت صور أو رسومات أو لقطات فيديو، أو ملفات صوتية أو

موسيقى، والمتعلقة القصة الرقمية وذلك أثناء تصميم السيناريو .

- اختيار برنامج الإنتاج: ويتمنك في اختيار البرنامج الذي سيتم تصميم الكتاب الإلكتروني به وهو يتمثل في برنامج flipping book والذي يتميز بإمكاناته الكبيرة فضلا عن سهولة استخدامه.

- اختبار البرامج المساعدة: وتتمنل في البرامج التي يمكن ان تستخدم لتُعين المصمم في إنتاجه للكتاب الإلكتروني وتمكنه من إنتاجه بشكل جيد مثل

.(Photoshop, movie maker,)

- الإنتاج المبدئي: ويُقصد به تتفيذ السيناريو حسب الخطة الموضوعة للحصول علي الكتاب الإلكتروني كما هو مخطط له.

مرحلة التقويم: شملت الخطوات الآتية:

- ثقويم بيئة التعلم: وتتمنت في عرض النسخة المبدئية من الكتاب الإلكتروني على مجموعة من المتخصصين في تكنولوجيا التعليم للتأكد من مناسبتها لتحقيق الأهداف، وتنلسل العرض، ومناسبة العناصر المكتوبة، والترابط والتكامل بينها، وسهولة الاستخدام، إضافة إلى كل النواحي التربوية والفنية الأخرى. - إجراء التعديلات: وتتمنل في إجراء التعديلات اللازمة على الكتاب الإلكتروني في ضوء النتائج التي نم الحصول عليها.

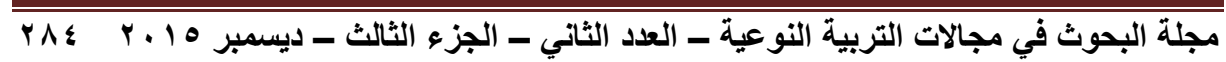


تنمية مهارات تصيميم القصة الرقمية باستخدام الكتاب الإلكتروني وعلاقتها بمستوي طموح معلمي المرحلة الابتدائية

- المراجعة النهائية: وتتمثل في مراجعة النسخة المبدئية وإضافة التعديلات

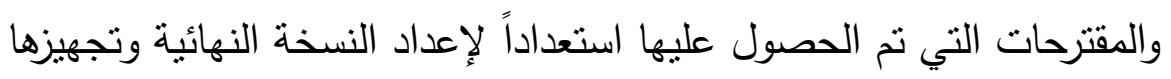

$$
\text { للعرض. }
$$

\section{مرحلة الاستخدام: شملت الخطوات الآتية:}

- استخدام بيئة التعلم الإكترونية: وتعنى استخدام الكتاب الإكتروني وتطبيقه

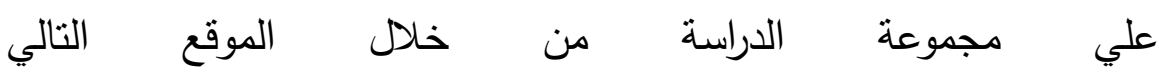
.https://digitalstoryskills.wordpress.com - متابعة الاستخدام: وتعني المتابعة المستمرة للكتاب الإكتروني لمعرفة الآراء

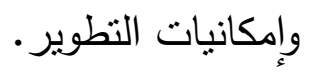

\section{سادسا ـ بناء ادوات الدراسةة:} اشتملت الدراسة علي الادوات الآتية: أ- قائمة مهارات القصة الرقمية

ب-الاختبار التحصيلي لقياس الجانب المعرفي الخاص بمهارات تصميم القصة الرقمية. ج-مقياس مستوي الطموح إعداد (محمد عبدالتواب، سيد عبدالعظيم، (r... O د - بطاقة تقييم المهارة لمهارات تصميم القصة الرقمية. أ- قائمة مهارات القصة الرقمية: - الهدف العام من بناء قائمة المهارات هو تحديد مهارات برنامج تصميم القصة الرقمية التي يمكن إكسابها لمعلمي المرحلة الابتدائية. - تحديد مصادر اشتقاق قائمة المهارات من خلال المقابلات مع العديد من

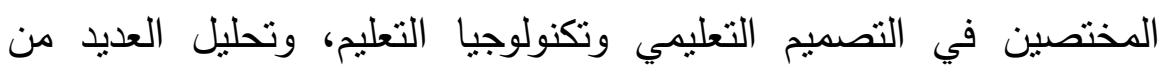
الادبيات والدراسات التي تتاولت مهارات تصميم القصة الرقمية. 
تنمية مهارات تصيميم القصة الرقمية باستخدام الكتاب الإلكتروني وعلاقتها بمستوي طموح معلمي المرحلة الابتدائية

- من خلا المقابلات والادبيات والدراسات تم اعداد الصورة المبدئية لقائمة المهارات وعرضها علي السادة المحكمين في مجال التخصص بهدف معرفة آرائهم واقتراحاتهم بشأن القائمة.

- بعد تحليل آراء المحكمين وجد أن هناك إجماعا من قبل المحكمين علي أهمية كلا من المهارات الرئيسة والفرعية حيث لم يرد أبي تعديلات جوهرية أنداء

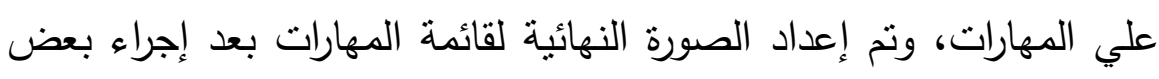
الاقتراحات اللغوية واحتوت القائمة علي (r أع) مهارة.

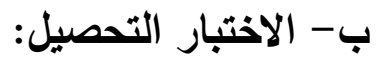

قام الباحث بإعداد الاختبار التحصيلي وفق الخطوات الآتية: ا. تحديد الغرض من الاختبار: هدف الاختبار التحصيلي الي قياس درجة

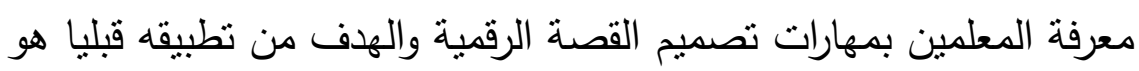
معرفة مدي امتلاك مجموعة الدراسة للمعارف السابقة في الجانب المعرفي للقصة الرقمية والهدف من تطبيقه بعديا هو مقارنه تحصيل مجموعة

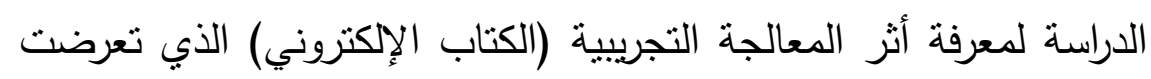
له مجموعة الدراسة. r. تحديد المستويات التي يهدف الاختبار لقياسها: اقتصر الاختبار التحصيلي

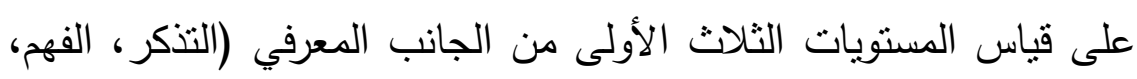
التطبيق).

r. إعداد جدول المواصفات: قام الباحث بإعداد جدول المواصفات الذى يحتوى على الأوزان النسبية لكل موضوع من الموضوعات والأوزان النسبية لكل

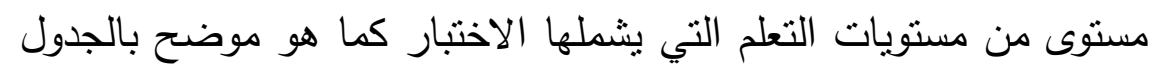

\begin{tabular}{|c|c|c|c|}
\hline \multicolumn{4}{|c|}{ جذول (ץ): مواصفات الاختبار التحصيلي } \\
\hline 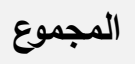 & 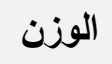 & مستويات الأهداف & الموضوع \\
\hline
\end{tabular}

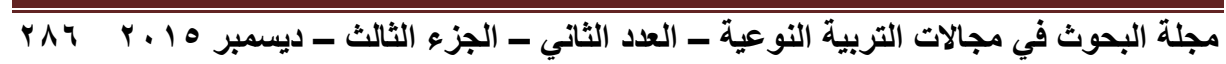


تنمية مهارات تصيميم القصة الرقمية باستخدام الكتاب الإلكتروني وعلاقتها بمستوي طموح معلمي المرحلة الابتدائية

\begin{tabular}{|c|c|c|c|c|c|}
\hline & النسبي & تطبيق & فهم & تذكر & \\
\hline r & $\% 7, \vee$ & - & 1 & 1 & للمعهوم القصة الإلكترونية وأنواعها وفوائدها \\
\hline V & \%rr,r & 0 & 1 & 1 & تصميم المشاهد والصور على أحد برامج \\
\hline V & r, & 0 & 1 & 1 & تعديل الصور علي برنامج تصميم القصة \\
\hline 7 & $\% r$. & $\varepsilon$ & 1 & 1 & تسجيل وحفظ الصوت والخلفيات \\
\hline$\Lambda$ & $\% r\urcorner, V$ & V & 1 & - & تركيب وتجميع مشاهد وصور القصة \\
\hline \multirow{2}{*}{ r. } & \multirow{2}{*}{$\% 1 \ldots$} & YI & 0 & $\varepsilon$ & المجموع \\
\hline & & $\% \vee$. & $\%, 7, V$ & س, & الوزن النسبي \\
\hline
\end{tabular}

ـ. تحديد نوع وعدد مفردات ودرجات الاختبار: تم اختيار مفردات الاختبار

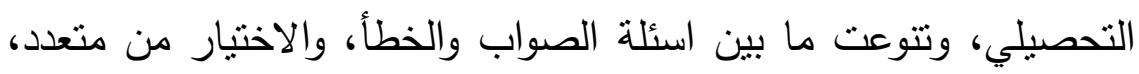

وعددها ·r مفردة، ولكل مفردة درجة واحدة ليصبح مجموع درجات

$$
\text { الاختبار • م درجة. }
$$

ه. صياغة مفردات وتعليمات الاختبار: تم صياغة مفردات الاختبار بالثكل الموضوعي في ضوء مستويات الأهداف وتكون الاختبار من ·r سؤال، 10 سؤال من نوع اسئلة الاختيار من متعدد، 10 سؤال من نوع اسئلة

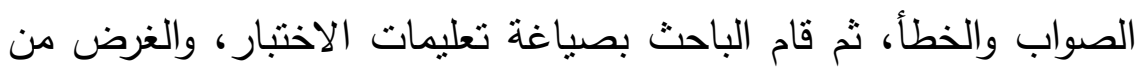
تعليمات الاختبار مراعاتها عند تطبيقه على معلمي المرحلة الابتدائية

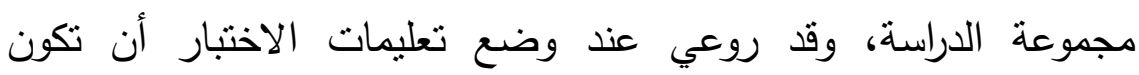


تنمية مهارات تصيميم القصة الرقمية باستخدام الكتاب الإلكتروني وعلاقتها بمستوي طموح معلمي المرحلة الابتدائية

التعليمات واضحة ومختصرة، ومحدد فيها بدقة الأداء المطلوب من المعلم القيام به.

7. الصورة المبدئية للاختبار: بعد صياغة مفردات الاختبار وتعليماته قام الباحث بصياغة مفردات الاختبار والتي تغطى عناصر المحتوى وتعكس لهن أهدافه، حيث بلغ عدد أسئلة الاختبار ثلاثون سؤالًا، تغطى المستويات الأول والثاني والثالث من تصنيف بلوم للأهداف المعرفية. V. التجربة الاستطلاعية للاختبار : في هذه الخطوة قام الباحث بنطبيث

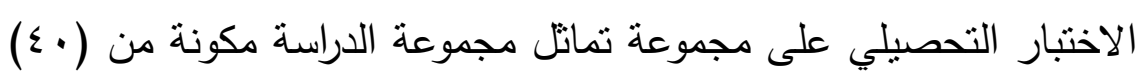
معلم، وذلك بهدف تحديد كل من:

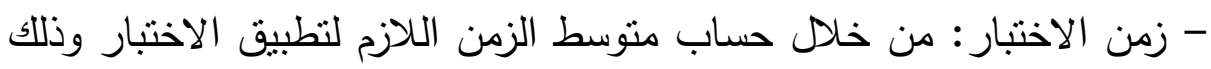
من خلال تطبيقه على المجموعة الاستطلاعية وتسجيل الزمن الذي استغرقه

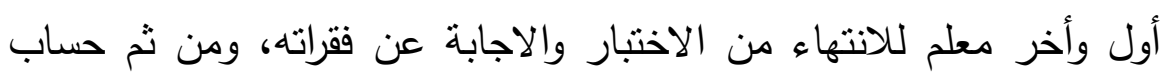

زمن الاختبار تبعا للمعادلة الآتية:

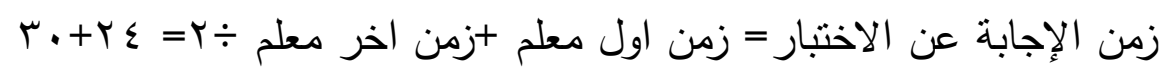

$$
\text { زتيقة }
$$

وقد نم الالتزام بهذا الزمن عند التطبيق القبلي والبعدي للاختبار التحصيلي على العينة الأساسية.

- حساب معاملات السهولة والصعوبة لمفردات الاختبار: تم حساب معامل السهولة والصعوبة لكل مفردة من مفردات الاختبار من خلال المعادلة

$$
\begin{aligned}
& \text { الآتية:(فؤاد البهي، و البهوله }
\end{aligned}
$$

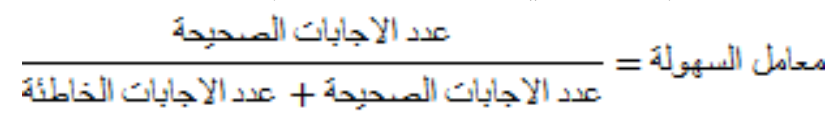

$$
\begin{aligned}
& \text { معامل الصعوبة= 1- معامل السهولة }
\end{aligned}
$$

وامتدت قيم معامل السهولة ما بين (VV,.)، (T0,.)) وامتدت قيم معامل 
تنمية مهارات تصيميم القصة الرقمية باستخدام الكتاب الإلكتروني وعلاقتها بمستوي طموح معلمي المرحلة الابتدائية

الصعوبة ما بين (0r,.))، (T/7,.) وهي قيم مقبولة إحصائيًا. - ثبات الاختبار : تم حساب ثبات الاختبار بطريقة اعادة الاختبار حيث تم تمثي

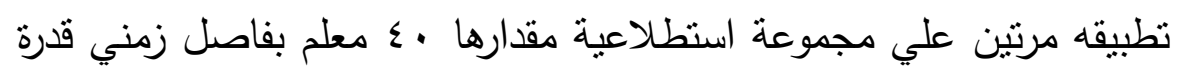

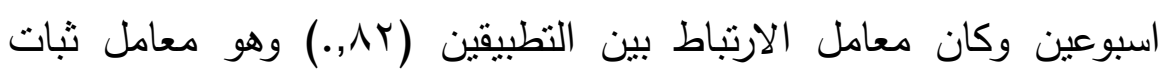
مُرضي •

- صدق الاختبار: بقصد بصدق الاختبار قدرته على قياس ما وضع لقياسه، وتم ذللك من خلال:

الصدق الظاهري: وهو الصدق المعتمد علي المحكمين، وتم التحقق من الصدق الظاهري بعد عرض الاختبار علي المحكمين وتتقيح الاختبار في ضوء اراء

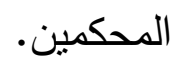
صدق الاتساق الداخلي: تم تطبيق الاختبار علي مجموعة استطلاعية مقدارها

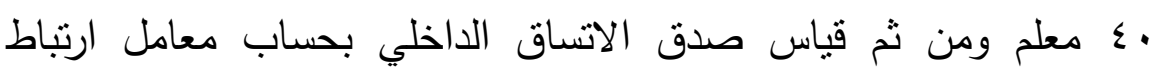
بيرسون بين درجة كل مستوي من مستويات الاختبار والدرجة الكلية للاختبار، وكانت قيم معامل ارتباط بيرسون دالة إحصائيًا عند مستوي دئي (1 (...) مما يدل اتساق مستويات الاختبار وصلاحيتها للتطبيق. ^ـ الصورة النهائية للاختبار : بعد حساب زمن الاختبار وثباته وصدقه أصبح الاختبار صالحًا للاستخدام في صورته النهائية، ويتكون الاختبار في صورته النهائية من كراسة الأسئلة التي تبدأ بتعليمات الاختبار الموجه لمعلمي المرحلة الابتدائية، ثم مفردات الاختبار التحصيلي المكون من عدد (•r) مفردة، وتتم الإجابة في كراسة الأسئلة. 9 ـ تقدير الدرجة وطريقة تصحيح الاختبار: استعان الباحث بنموذج لتصحيح التهابه الاختبار التحصيلي الذى أعده واستخدمه أثناء تصحيحه لأوراق الأسئلة

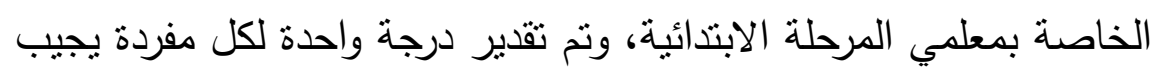

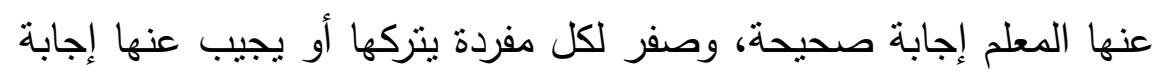


تنمية مهارات تصيميم القصة الرقمية باستخدام الكتاب الإلكتروني وعلاقتها بمستوي طموح معلمي المرحلة الابتدائية

خطأ، على أن تكون الارجة الكلية للاختبار تساوى عدد مفردات الاختبار

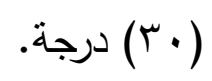

ج- مقياس مستوي الطموح: 1-وصف مقياس مستوي الطموح

قام بإعداد هذا المقياس (محمد عبدالتواب، سيد عبدالعظيم، 0. . ب) ويتكون المقياس من جس عبارة موزعة علي أربعة أبعاد هي:

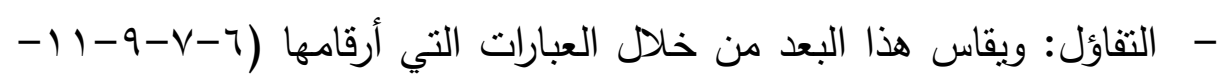

$$
\text { . (rr-r r-rO-r }
$$

- المقدرة علي وضع الأهداف: ويقاس هذا البعد من خلال العبارات التي

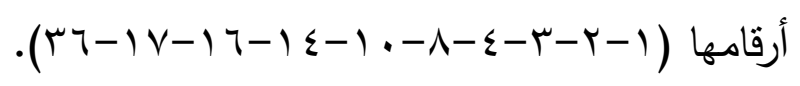

- تقبل الجديد: ويقاس هذا البعد من خلص العبارات التي أرقامها (10-1 (1)

$$
\text { . (ro-r (r) }
$$

- تحمل الاحباط: ويقاس هذا البعد من خلال العبارات التي أرقامها (0-. (r-

$$
\begin{aligned}
& .(r V-r r-r Y-r) \\
& \text { r - صدق المقياس: }
\end{aligned}
$$

قام الباحث بإجراء دراسة استطلاعية لمقياس مستوي الطموح من خلال تطبيقه علي مجموعة من معلمي المرحلة الابتدائية بلغ عددهم (• ع) معلم من

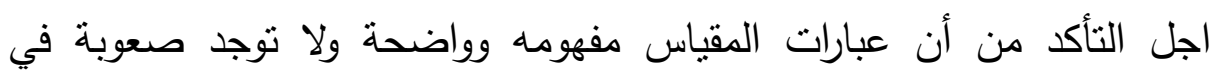
الاجابة عليها والتأكد من صدق وثبات المقياس في البيئة المحلية كما يلي:

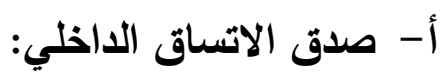
تم حساب معاملات الارتباط بين كل عبارة ومجموع درجة البعد الذي تتنمي إليه وارتباط كل بعد بالدرجة الكلية للمقياس، وارتباط كل بعد من ابعاد

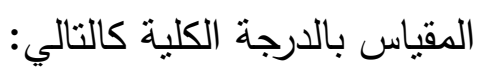
- معامل ارتباط كل عبارة بالبعد الذي تتمي اليه، وامتذت معاملات الارتباط ما

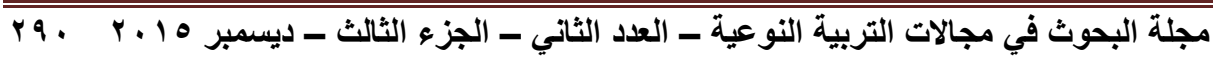


تنمية مهارات تصيميم القصة الرقمية باستخدام الكتاب الإلكتروني وعلاقتها بمستوي طموح معلمي المرحلة الابتدائية

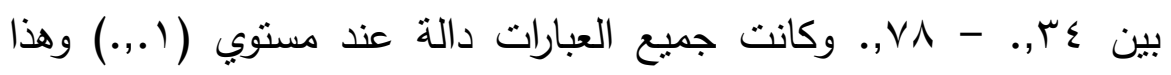
يعطي دلالة علي ارتفاع معامل الاتساق الداخلي.

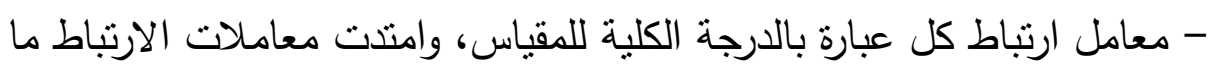

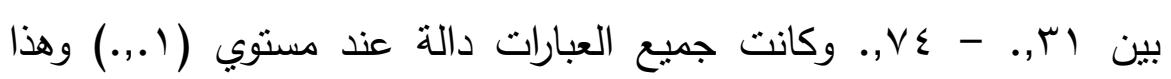
يعطي دلالة علي ارتفاع معامل الاتساق الداخلي.

- معامل ارتباط كل بعد من ابعاد المقياس بالدرجة الكلية للمقياس، كالتالي:

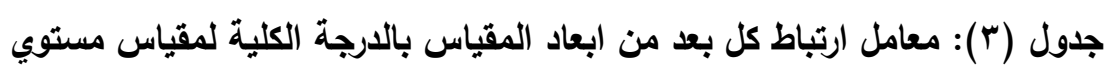

\begin{tabular}{|c|c|c|c|}
\hline \multicolumn{4}{|c|}{ الطموح } \\
\hline مستوي الدلالة & معامل الارتباط & الأبعاد & 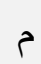 \\
\hline., .1 &., 19 & التقاؤل & 1 \\
\hline., .1 &.,$\wedge \varepsilon$ & المقرةة علي وضع الأهداف & r \\
\hline., .1 &.,$\vee \leqslant$ & تقبل الجديد & r \\
\hline., .1 & $., \wedge)$ & تحمل الاحباط & $\varepsilon$ \\
\hline
\end{tabular}

يتضح من النتائج ان جميع العبارات دالة عند مستوي (1...) وهذا

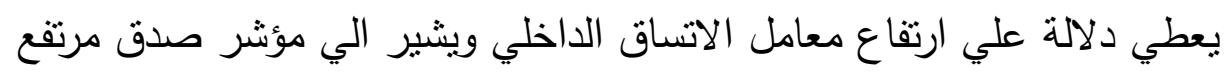
مما يؤكد صدق المقياس وامكانية الاعتماد عليه في تطبيق الدراسة. ب- صدق المقارنة الطرفية (الصدق التمييزي): تم حساب الفروق بين منوسطات درجات مجموعة الإرباعي الأعلى ومتوسطات مجموعة الإرباعي الأدنى باستخدام اختبار تت لدلالة الفروق بين المتوسطات. جدول (؛ ): صدق المقارنة الطرفية (الصدق التمييزي) لمقياس مستوي الطموح 
تنمية مهارات تصميم القصة الرقمية باستخدام الكتاب الإكتروني وعلاقتها بمستوي طموح معلمي

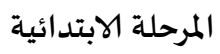

\begin{tabular}{|c|c|c|c|c|c|c|}
\hline \multirow{2}{*}{ مستوي } & \multirow[t]{2}{*}{ قيمة ت } & \multicolumn{2}{|c|}{ 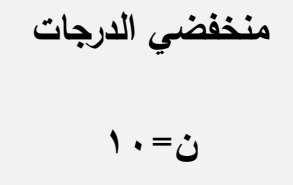 } & \multicolumn{2}{|c|}{ 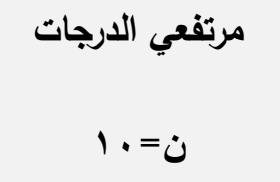 } & \multirow[t]{2}{*}{ الأبعاد } \\
\hline & & $\varepsilon$ & b & $\varepsilon$ & r & \\
\hline., .0 & $r, 1 \wedge$ & $\varepsilon, 9$ & $r \varepsilon, q r$ & $r, 1 \wedge$ & $r V, V r$ & التقاؤل \\
\hline., .0 & $r, \varepsilon$ & $\varepsilon, \vee V$ & $1 \wedge, 94$ & $Y, V T$ & דr, & المقدرة على وضع \\
\hline., .0 & r,oג & r, & 17,7 . & $Y, \varepsilon\rceil$ & $r \cdot, r u$ & تقبل الجديد \\
\hline., .0 & r, ro & r, r & $M, \Lambda$. & $1, \wedge 0$ & $M, \Lambda$. & تحمل الاحباط \\
\hline., .0 & r,vr & $11, V V$ & $10, \cdot 7$ & $7, Y V$ & $10, \cdot 7$ & الارجة الكلية \\
\hline
\end{tabular}

يتضح من جدول (ع) وجود فروق ذات دلالة احصائية عند مستوي

ه... بين مرتفعي ومنخفضي الدرجات علي جميع ابعاد مقياس مستوي الطموح

والدرجة الكلية للمقياس وهذا يعني أن المقياس صادق.

ب- ثباث المقياس:

قام الباحث باستخدام طريقة معامل الفاكرونباخ لجميع ابعاد المقياس

والدرجة الكلية كما في الجدول الآتي:

جدول (•): معامل الفاكرونباخ لجميع ابعاد المقياس والدرجة الكلية

\begin{tabular}{|c|c|c|}
\hline معامل ثبات الفاكرونباخ & 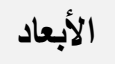 & م \\
\hline.,$V \leqslant$ & التفاؤل & 1 \\
\hline
\end{tabular}

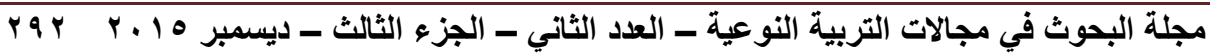


تنمية مهارات تصيميم القصة الرقمية باستخدام الكتاب الإلكتروني وعلاقتها بمستوي طموح معلمي

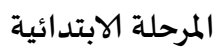

\begin{tabular}{|c|c|c|}
\hline.,$V 7$ & المقدرة علي وضع الأهداف & r \\
\hline.,$\vee \wedge$ & تقبل الجديد & r \\
\hline.,$\Lambda Y$ & تحمل الاحباط & $\varepsilon$ \\
\hline.,$\wedge r$ & الدرجة الكلية & \\
\hline
\end{tabular}

يتضح من جدول (0) أن قيمة معامل الثبات للارجة الكلية للمقياس rیر,. وهي قيمة مرثفعة تدل علي ثبات المقياس وصلاحيته للاستخدام. צ - تصحيح المقياس:

تتراوح الدرجة الكلية للمقياس ما بين (صفر - 1 - () ولقد وضعت أربعة بدائل للإجابة عن كل بند من بنود المقياس وهي: دائما (ب درجات)، كثيرا (درجتان)، احيانا (درجة واحدة)، نادرا (صفر)، وتعكس هذه الدرجات في البنود

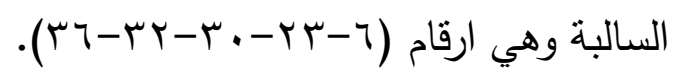
د - بطاقة تقييم المهارة:

تم إعداد بطاقة تقييم المهارة لمهارات تصميم القصة الرقمية من خلال الخطوات الآتية: - ت إن

الهرف من بطاقة تقييم المهارة: تقييم أداء معلمي المرحلة الابتدائية في مهارات تصميم القصة الرقمية. عناصر البطاقة: في ضوء الأهداف الإجرائية المهارية، والمحتوى العلمي، قام الباحث بصياغة عناصر بطاقة تقييم المهارة بحيث اثتملت على (rع) مهارة خاصة بتصميم القصة الرقمية، وقد روعي صياغتها في جمل بسيطة يسهل قياسها، وفى صورة أفعال سلوكية. أسلوب التقدير المستخدم: قائمة التقدير وقد استخدم فيها أسلوب التقدير الكمي 
تنمية مهارات تصيميم القصة الرقمية باستخدام الكتاب الإلكتروني وعلاقتها بمستوي طموح معلمي المرحلة الابتدائية

بالدرجات حتى يمكن التعرف على مستوي المعلم في كل مهارة بصورة موضوعية، بحيث إذا كان أدائه صحيحًا يحسب له درجتين واذا كان متوسطا تحسب له درجة واحدة، أما إذا لم يؤدى المهارة أو أداها بشكل خاطئ يحسب له له له

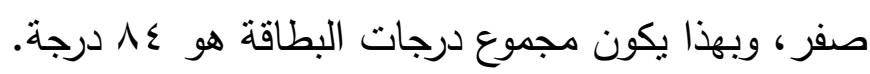
تعليمات بطاقة تقييم المهارة: بعد صباغة بنود بطاقة تقييم المهارة، قام الباحث

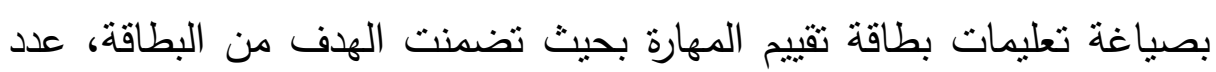

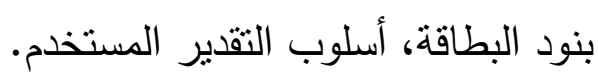
ضبط بطاقة تقييم المهارة: - ثبات بطاقة تقييم المهارة: استخدم الباحث طريقة الاتفاق بين الملاحظين لحساب معامل الثبات الخاص ببطاقة تقييم المهارة، حيث استعان الباحث باثثين من اخصائي التكنولوجيا بالمدرسة وذللك لتقييم أداء المعلمين، وذلك

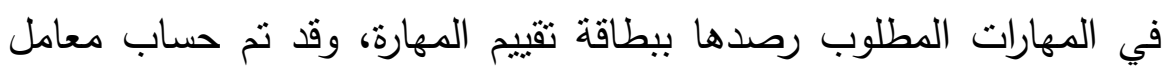
الاتفاق بين الملاحظين عن طريق التعويض في معادلة كوبر Cooper

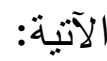

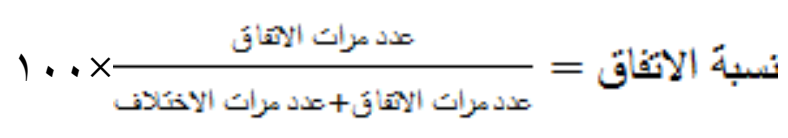

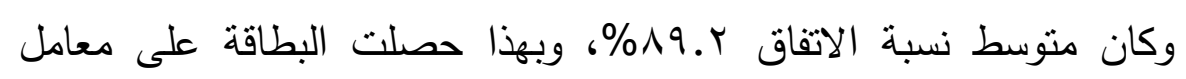
ثبات مرتفع حيث حدد كوبر Cooper مستوى الثبات بدلالة نسبة الاتفاق فذكر أنه إذا كانت نسبة الاتفاق أقل من • V\% فهذا يعبر عن انخفاض ثبات

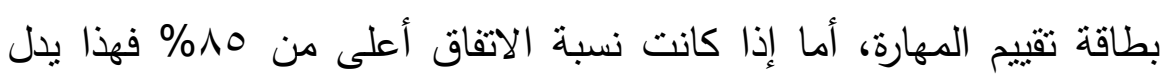
على ارتفاع ثبات بطاقة تقييم المهارة.

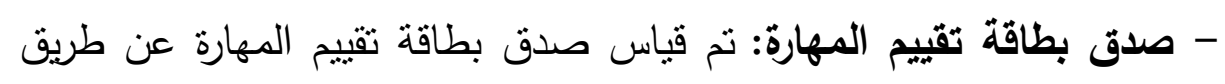
الصدق الظاهري، الذى يعنى عرض البطاقة على مجموعة من المحكمين،

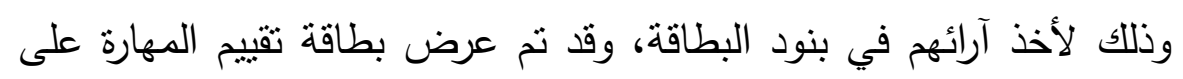


تنمية مهارات تصيميم القصة الرقمية باستخدام الكتاب الإلكتروني وعلاقتها بمستوي طموح معلمي المرحلة الابتدائية

المحكمين لتعرف آرائهج، وقد قام الباحث بتعديل بنود بطاقة تقييم المهارة وفق آراء المحكمين وإعدادها في صورتها النهائية. الصورة النهائية لبطاقة تقييم المهارة: بعد التأكد من ثبات بطاقة تثبينم المهارة

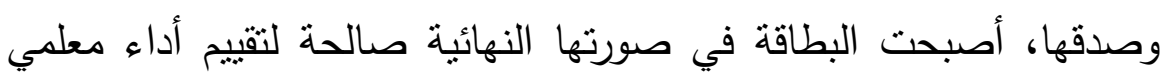
المرحلة الابتدائية مجموعة الدراسة لمهارات تصميم القصة الرقمية. سابعا: تنفيذ تجرية الدراسة: مرت مرحلة تتفيذ تجربة الدراسة بالخطوات الاتية: أ- تطبيق التجربة الاستطلاعية للاراسة: قام الباحث بتطبيث التجربة بلتهن الاستطلاعية للبحت علي مجموعة من معلمي المرحلة الابتدائية بمدرسة

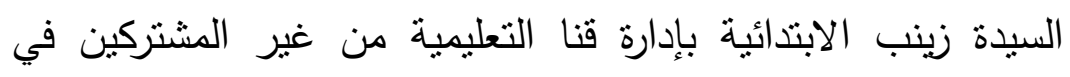
التجربة الأساسية وعددهم • • معلم، وشمل ذلانك التطبيق استخدام الكتاب الإلكتروني، والاختبار التحصيلي، ومقياس مستوي الطموح.

\section{الهذف من تطبيق التجرية الاستطلاعية}

- التعرف على المشكلات التي يمكن ان تقابل الباحث في اثناء إجراء التجربة الأساسية، ومحاولة التغلب عليها.

- تقدير مدي ثبات أداتي الدراسة (الاختبار التحصيلي، مقياس مستوي الطموح) ومدي صلاحيتها للتطبيق، تقدير الزمن اللازم لتطبيق اداة الدراسة.

نتائج التجربة الاستطلاعية

كثفت نتائج التجربة الاستطلاعية عن جاهزية اداتي الدراسة ومادة المعالجة التجريبية للنطبيق. ب- التجرية الأساسية للاراسة بعد الانتهاء من اجراء التجربة الاستطلاعية، ثم اجراء التجربة الأساسية للاراسة

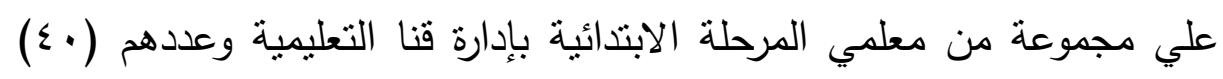


تنمية مهارات تصيميم القصة الرقمية باستخدام الكتاب الإلكتروني وعلاقتها بمستوي طموح معلمي

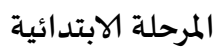

معلم.

نتائج الاراسة وتفسيرها:

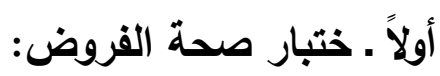

اختبار صحة الفرض الأول والذي ينص علي: لا يوجد فرق دال إحصائيًا عند مستوي (1 (..) بين منوسطي درجات التطبيقين القبلي والبعدي لاختبار التحصيل في الجانب المعرفي المتعلق بتصميم القصة الرقمية،

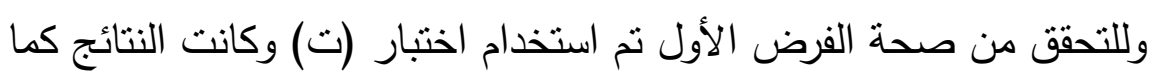

$$
\text { (7) بوضحها جدول }
$$

جدول (†): نتائج المعالجة الاحصائية لارجات المعلمين في اختبار التحصيل

\begin{tabular}{|c|c|c|c|c|c|}
\hline مستوي الالالة عند & قيمة & العينة & الانعراف & الحسابي & التطبيق \\
\hline \multirow{2}{*}{ دالة } & \multirow{2}{*}{$0 ৭, \Gamma \leqslant$} & $\varepsilon$. & $1, \cdot 1$ & $\varepsilon, O r$ & القبلي \\
\hline & & $\varepsilon$. & $1,7 V$ & $r, q . q$. & البعدي \\
\hline
\end{tabular}

يتضح من الجدول رقم (T) أن قيمة "ت" تساوى (ع (ب.09) وهذه القيمة

دالة عند مستوي (1 •,.)، مما يدل على ان هناك فرقا لصالح التطبيق البعدي

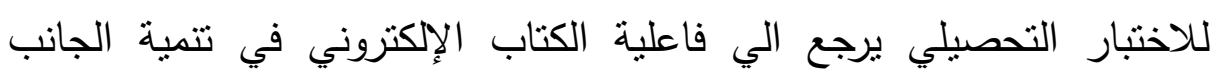
المعرفي المتعلق بالقصة الرقمية، وهذا يؤكد خطأ الفرض الأول.

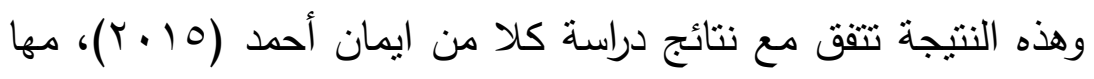

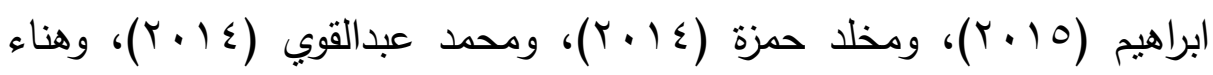

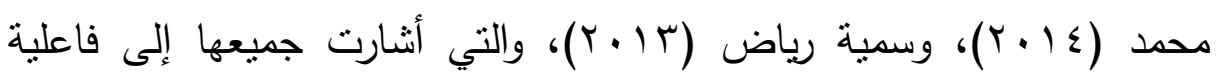
الكتاب الإلكتروني في تتمية التحصيل لدي مجموعة الدراسة والتي استخدم الكتاب الإكتروني في التدربس. اختبار صحة الفرض الثاني والذي ينص علي: لا يوجد فرق دال 
تنمية مهارات تصيميم القصة الرقمية باستخدام الكتاب الإلكتروني وعلاقتها بمستوي طموح معلمي المرحلة الابتدائية

إحصائيًا عند مستوي ( ( ..) بين منوسطي درجات التطبيقين القبلي والبعدي

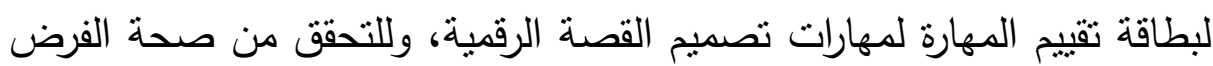

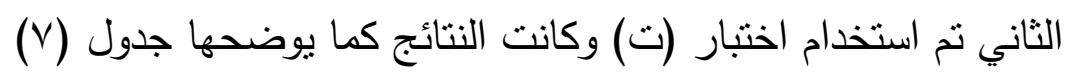
جدول (V): نتائج المعالجة الاحصائية لارجات المعلمين في بطاقة تقييم المهارة

\begin{tabular}{|c|c|c|c|c|c|}
\hline عند مستوي الدلالة & قيمة & (ن) & الانحراف & الحسابي & التطبيق \\
\hline \multirow{2}{*}{ دال } & \multirow{2}{*}{$(19,9)$} & $\varepsilon$. & $r, V T$ & $10,{ }_{0}$ & القبلي \\
\hline & & $\varepsilon$. & $\Gamma, Y \varepsilon$ & $V 7, .0$ & البعدي \\
\hline
\end{tabular}

يتضح من الجدول السابق أن قيمة "ت" تساوى (19.9) وهذه القيمة دالة عند مستوي (1 •,.•)، مما بدل على ان هناك فرقا لصالح التطبيق البعدي

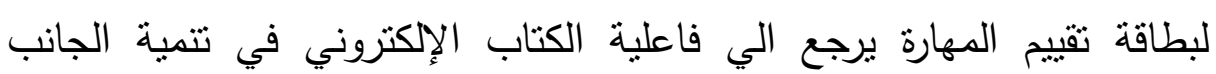
الادائي المتعلق بالقصة الرقمية، وهذا يؤكد خطأ الفرض الثاني.

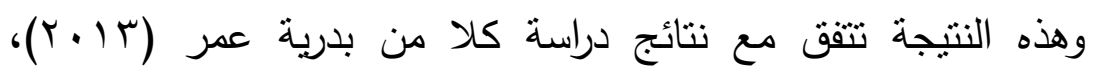

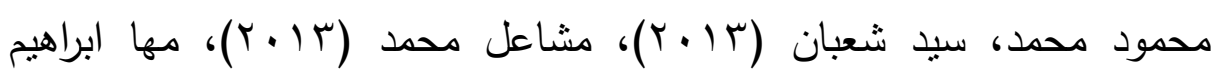

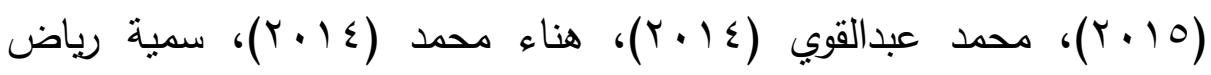

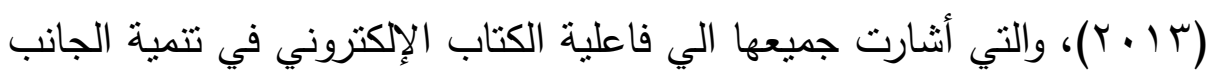
الادائي لدي مجموعة الدراسة التي تستخدم الكتاب الإلكتروني. اختبار صحة الفرض الثالث والذي ينص علي: لا توجد علاقة ارتباطية دالة إحصائًاً عند مستوي (1 (.. ) بين مستوي الطموح ومهارات تصميم القصة الرقمية، وللتحقق من صحة الفرض الثالث تم استخدام معامل ارتباط بيرسون بين درجات المعلمين في مستوي الطموح ودرجاتهم في الجانب الادائي لمهارات

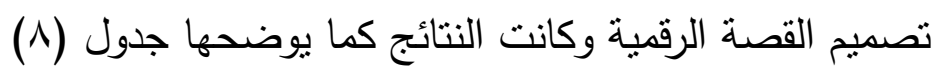
جدول (^): معامل ارتباط بيرسون بين مستوي الطموح ومهارات تصميم القصة الرقمية 
تنمية مهارات تصيميم القصة الرقمية باستخدام الكتاب الإلكتروني وعلاقتها بمستوي طموح معلمي

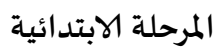

\begin{tabular}{|c|c|c|c|}
\hline مستوي الدلالة & معامل الارتباط & ابعاد مستوي الطموح & 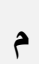 \\
\hline$\ldots 1$ & $\cdot, Y V$ & التفاؤل & 1 \\
\hline. .1 & דוז, & المقدرة علي وضع الأهداف & r \\
\hline$\ldots 1$ & $\cdot, \Gamma \wedge$ & تقبل الجديد & r \\
\hline$\ldots 1$ & $\cdot, \varepsilon$. & تحمل الاحباط & $\varepsilon$ \\
\hline$\ldots 1$ & $\cdot, 0$. & الدرجة الكثية & 0 \\
\hline
\end{tabular}

يتضح من الجدول رقم (^) وجود علاقة موجبة ذات دلالة احصائية بين درجات المعلمين في مستوي الطموح ودرجاتهم في الجانب الادائي لمهارات تصميم القصة الرقمية، وهذا يعني انه كلما ارتفع مسنوي الطموح ارتفع مستوي الأداء لمهارات تصميم القصة الرقمية، وهذا يؤكد خطأ الفرض الثالث. وتتفق هذه النتيجة مع دراسات كلا من محاسن محمد (T 1 ( ؟)، هالة

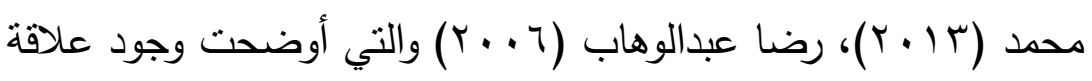
ذات دلالة احصائية بين مستوى الطموح ومهارات تصميم القصة الرقمية لدى الطلاب.

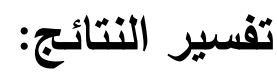
ويمكن تفسير فاعلية الكتاب الإككتروني المستخدم في هذه الدراسة لتتمية مهارات تصميم القصة الرقمية لدي معلمي المرحلة الابتدائية بما يلي:

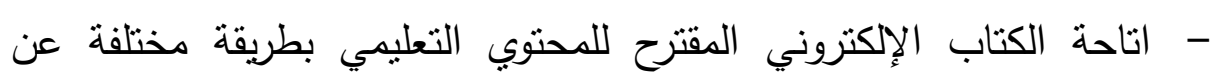

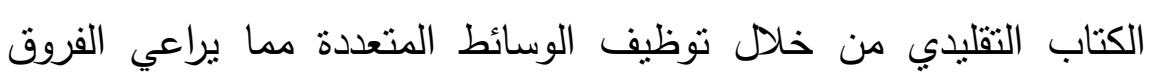

$$
\text { الفردية وهذا يؤدي الي فهم أقوي لمحتوي الكتاب. }
$$

- وجود بيئة تعلم نشطة تتيح التحكم الكامل في أسلوب عرض الكتدي الكتاب وتوفر

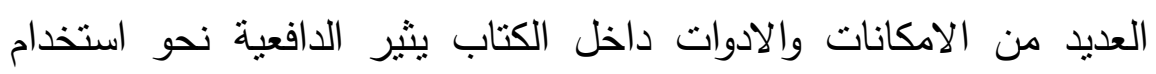

$$
\text { الكتاب الإلكتروني واستيعاب محتواه. }
$$

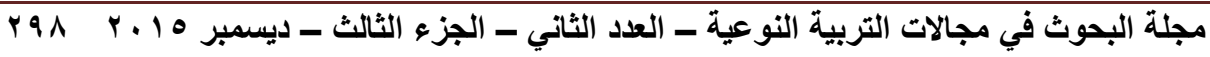


تنمية مهارات تصيميم القصة الرقمية باستخدام الكتاب الإلكتروني وعلاقتها بمستوي طموح معلمي المرحلة الابتدائية

- اتاحة الكتاب الإكتروني عبر شبكة الإنترنت اتاح حرية استخدامه في أي وقت وأي مكان مما ينعكس علي رفع معدل استخدامه والاستفادة من

$$
\text { محتواه. }
$$

- - عرض الكتاب لمهارات تصميم القصة الرقمية بصورة منسلسلة سهل اتقان هذه المهارات وتطبيقها.

التوصيات والدراسات المقترحة:

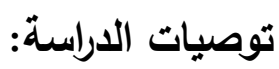

في ضوء ما توصلت اليه الدراسة الحالية من نتائج يوصي الباحث بما يلي: - - الاستفادة من نتائج الدراسة الحالية في تتمية مهارات الطلاب لتصميم القصة

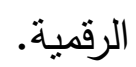

- - - استخدام الكتاب الإلكتروني في تدريب المعلمين بدلا من الطريقة التقليدية. - - تصميم الكتب الإلكترونية بجانب الكتب الورقية للمواد المختلفة في المدارس من والجامعات.

- - التعرف علي الاحتياجات النفسية للمعلمين عن طريق إجراء البحوث النفسية عليهم. - اثرالك المعلمين في الانشطة والتدريبات التي تزيد من فاعليتهم وتربطهم أكثر بواقعهم.

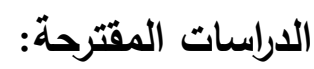
يقترح الباحث اجراء مزيد من الدراسات في المجالات الآتية: - - - اجراء دراسات لتتمية الاتجاهات الايجابية نحو القصة الرقمية. 
تنمية مهارات تصيميم القصة الرقمية باستخدام الكتاب الإلكتروني وعلاقتها بمستوي طموح معلمي المرحلة الابتدائية

- - اكساب مهارات القصة الرقمية لدي كل من الطلاب والمعلمين. - - اجراء دراسات مماثلة لاستخدام الكتاب الإلكتروني وعلاقته بمستوي الرضا. - اجراء دراسات ممانتة لتتمية مستوي الطموح لدي المعلمين. - - دراسة العلاقة بين المستحدثات التكنولوجية ومستوي الطموح لاي الطلاب دئل المعلمين.

\section{المراجع والمصادر : - المعين

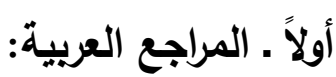

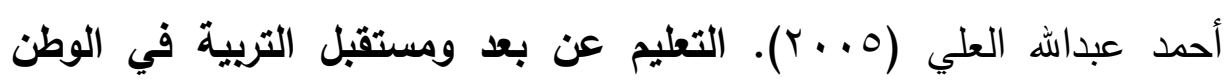
العربي، القاهرة: دار الكتاب الحديث.

أحمد عزت راجح (9V7 (1). اصول علم النفس، الاسكندرية، المكتب المصري الحديث. أحمد فايز أحمد ( • ( ب). الكتاب الإكتروني إنتاجه ونشره، السلسلة الثانية (V乏) )، الرياض: مطبوعات مكتبة الملك فهد الوطنية.

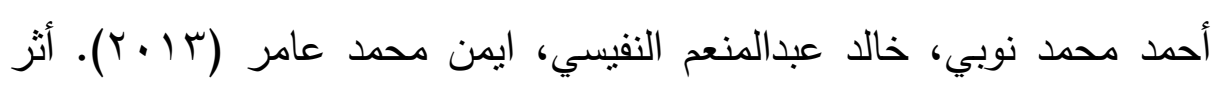
تتوع أبعاد الصورة في القصة الإلكترونية على تتمية الذكاء المكاني

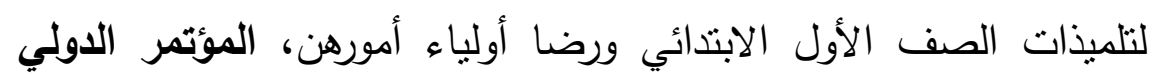
الثالث للتعلم الإكتروني والتعليم عن بعد، المركز الوطني للتعلم

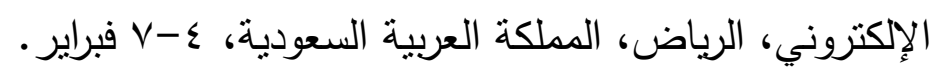

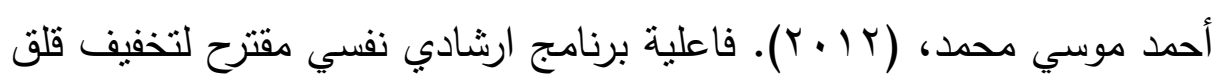
المستقبل واثثة علي دافعية الانجاز ومستوي الطموح لدي طلاب كلية المجتمع بجامعة جازان، رسالة دكتوراه، كلية العلوم الاجتماعية، جامعة الامام محمد بن سعود الاسلامية، السعودية.

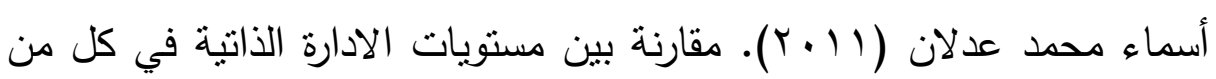


تنمية مهارات تصيميم القصة الرقمية باستخدام الكتاب الإلكتروني وعلاقتها بمستوي طموح معلمي المرحلة الابتدائية

مركز التحكم ومستوي الطموح وفاعلية الذات لدي طلاب الجامعة، رسالة ماجستير ، معهد الدراسات التربوية، جامعة القاهرة.

آمال أحمد يعقوب (919 (1)). علم النفس الاجتماعي، بغداد: المكتبة الوطنية. آمال عبدالسميع باظة (ع ...ץ). مقياس مستوي الطموح لاي المراهقين والثباب، القاهرة: مكتبة الانجلو المصرية.

إيمان أحمد مصطفي (10 ب ب). أثز أنماط التقاعل مع النص والصورة داخل الكتاب الإكتروني في التحصيل الفوري والمرجأ لتلاميذ المرحلة الابتدائية وتتمية اتجاهاتهم نحو الكتب الإلكترونية، رسالة دكتوراه، كلية التربية النوعية، جامعة بورسعيد.

إيناس أبوبكر محمد (ع (Y). برنامج كمبيوتز لتتمية مهارة حل المشكلات

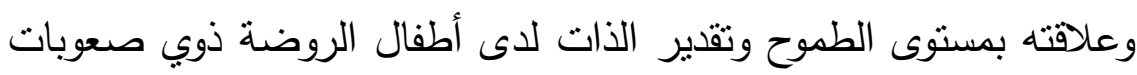
التعلم، رسالة دكتوراه، كلية رياض الأطفال، جامعة القاهرة. إيهاب حمزة (ع ( • Y). اثر الاختلاف في نمطي تقديم القصة الرقمية التعليمية في التحصيل الفوري والمرجأ لدي تلاميذ المرحلة الابتدائية، دراسات عربية

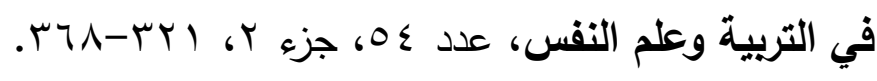

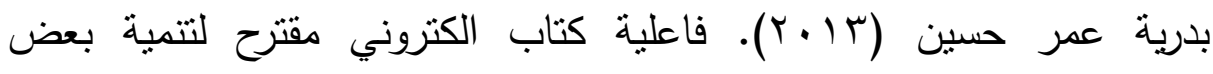
المهارات الاعرابية لدي طالبات المرحلة الثانوية بمدينة جدة، رسالة ماجستير، برنامج الدراسات العليا التربوية، جامعة الملك عبدالعزيز . جليل وديع شكور (99V (19). تأثثير الاهل في مستقبل ابنائهم علي صعيد التوجيه المدرسي والمهني، بيروت: مؤسسة المعارف للنشر والتوزيع.

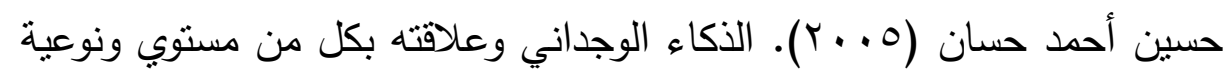

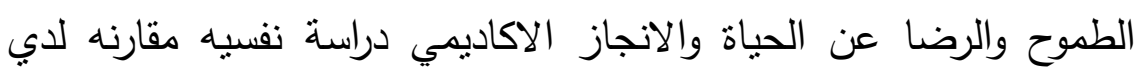
طلاب الجامعة، رسالة ماجستير، كلية الآداب، جامعة عين شمس. حسين محمد عبدالباسط (· ( ·). فاعلية برنامج مقترح قائم علي استخدام

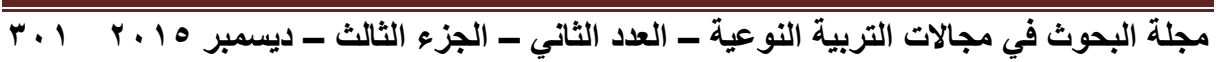


تنمية مهارات تصيميم القصة الرقمية باستخدام الكتاب الإلكتروني وعلاقتها بمستوي طموح معلمي المرحلة الابتدائية

برمجية photostory3 في تتمية مفهوم ومهارات تصميم وتطوير القصص الرقمية اللازمة لمعلمي الجغرافيا قبل الخدمة، مجلة الجمعية التريوية

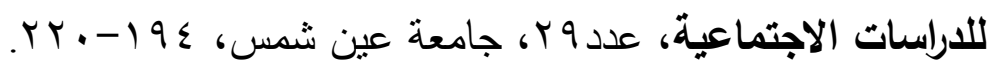

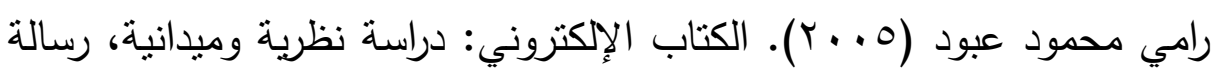
ماجستير ، كلية الآداب، جامعة المنوفية.

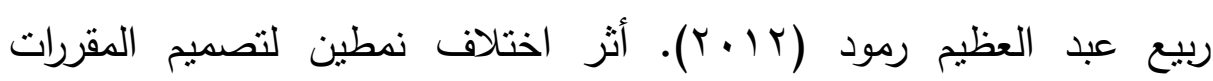
الإلكترونية والأسلوب المعرفي على زيادة التحصيل لدى الطلاب المعلمين

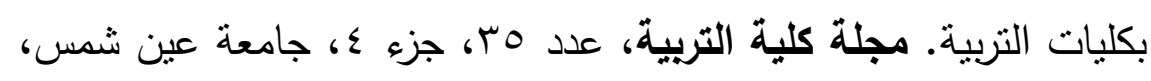

$$
.11 \leqslant-79
$$

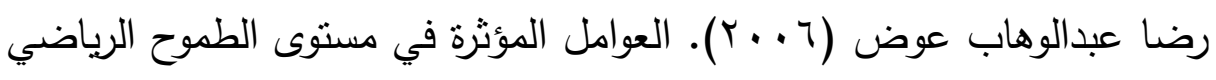
وعلاقتها بمستوى الانجاز لناشئي الكرة الطائرة، رسالة ماجستير، كلية التربية الرياضية، جامعة الاسكندرية. رزية الغربب (99 (99). التعلم دراسة نفسية-تفسيرية-توجيهية، القاهرة: مكتبة الانجلو المصرية.

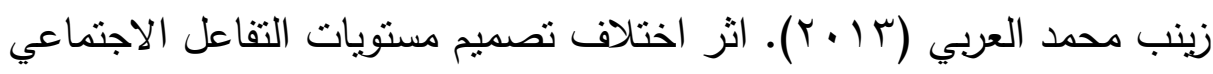
في القصص الرقمية التعليمية عبر الويب في تتمية التقكير التأملي لدي طلاب تكنولوجيا التعليم واتجاهاتهم نحوها، دراسات في المناهج وطرق

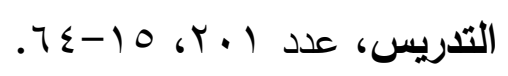

سعد خليفة عبدالكريم (11) (Y). فعالية التعليم الفردي الذاتي بالمحاكاة بالكمبيوتر والكتاب الإكتروني في تتمية التفكير الابتكاري لدى طلاب العلوم بالفرقة الثانية بكلية التربية بسلطنة عمان: دراسة تجريبية، مجلة كلية

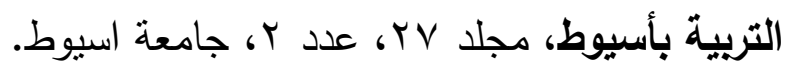
سلوى عثمان، هناء حافظ (999 (19). ابعاد العملية الاتصالية، الاسكندرية، المكتب الجامعي الحديث.

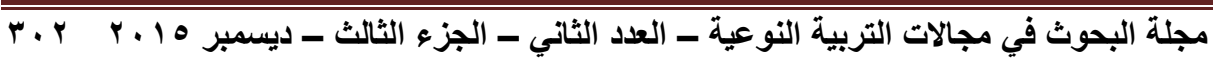


تنمية مهارات تصيميم القصة الرقمية باستخدام الكتاب الإلكتروني وعلاقتها بمستوي طموح معلمي المرحلة الابتدائية

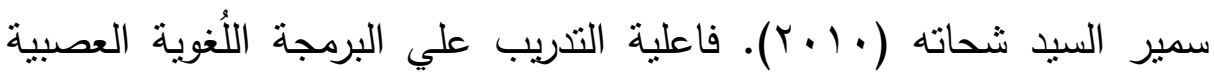
والعلاج المعرفي السلوكي لتعديل مستوي الطموح لدي عينة من المراهقين ذوي الإعاقة السمعية وأثزه في السلوك التكيفي، رسالة دكتوراه، كلية التربية، جامعة كفر الثيخ.

سهير كامل أحمد (999 (1). أساليب تريبة الطقل بين النظرية والتطبيق، الاسكندرية: مركز الاسكندرية للكتاب.

سوسن محمود أحمد (Y. (Y). فاعلية بعض متغيرات تصميم الكتاب الإكتروني في التحصسيل ومهارات التعلم الذاتي والانطباعات لدي الطالبات المعلمًات في مقرر تكنولوجيا التعليم، رسالة ماجستير، كلبـة البنـات، جامعـة عين شـس.

سيد عبدالعظيم محمد (Y9Y ( 99 ). دراسة لمستوى الطموح وعلاقته ببعض القدرات العقلية والسمات الانفعالية للشخصية خلال بعض مراحل النمو، رسالة

ماجستير ، كلية التربية، جامعة المنيا. شريف مهني عبده (1 (. (Y). دراسة الاغتراب وعلاقته بمستوي الطموح لدي طلاب الثانوي العام والفني الصناعي، رسالة ماجستير، معهد الدراسات العليا للطفولة، جامعة عين شمس. صابر حجازي عبدالمولى ( (9^1)). دراسة لعدد من الدوافع النفسية لدي المراهقين المصربين من حيث علاقتها ببعض المتغيرات البيئية في المجتمع المصري، رسالة دكتوراه، كلية التربية، جامعة المنيا. صفوت أحمد عبدربه (990 (19). دراسة مقارنة لمستوي الطموح وعلاقته بالإنجاز الأكاديمي علي عينة من طلبة المدارس الثانوبة من بدو جنوب سيناء والحضر، رسالة ماجستير، معهد الدراسات العليا للطفولة، جامعة عين

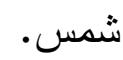

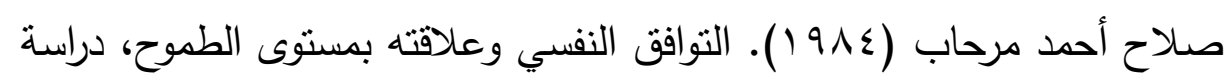

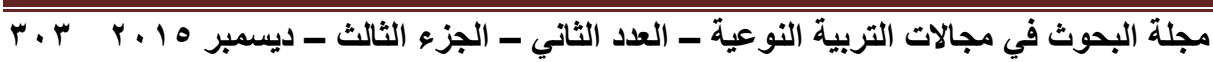


تنمية مهارات تصميم القصة الرقمية باستخدام الكتاب الإلكتروني وعلاقتها بمستوي طموح معلمي المرحلة الابتدائية

مقارنه بين الجنسين في مرحله المراهقة بالمغرب، رسالة دكتوراه، معهد الدراسات العليا للطفولة، جامعة عين شمس. صلاح أحمد مرحاب (919 (1)). سيكولوجية التوافق النفسي ومستوي الطموح، الرباط: دار الايمان للنشر والتوزيع. عبدالرحمن سيد سلمان (9v9 (1). نمو الانسان في الطقولة والمراهقة، القاهرة: مكتبة زهراء الثرق.

عبدالقادر كراجه (99V) (197). سيكولوجية التعلم، عمان: دار اليازوري العلمية للنشر والتوزيع. عصام شوقي شبل (^ . . r). أثز اختلاف واجهة تفاعل الكتاب الإلكتروني على التحصيل المعرفي والأداء المهارى لدى دارسي ماجستير تقنيات التعليم

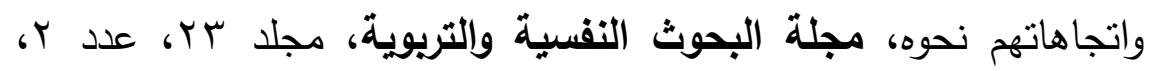

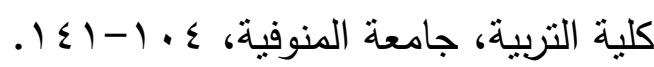
علاء عبداله أحمد (r/r). استخدام القصص الرقمية التاريخية لتتمية التعاطف التاريخي لدي تلاميذ الصف الثالث الاعدادي، مجلة دراسات في

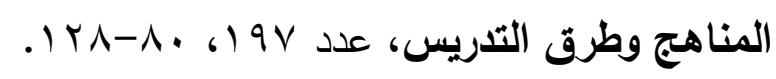

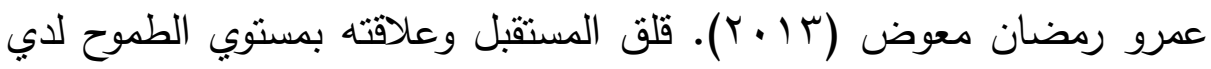

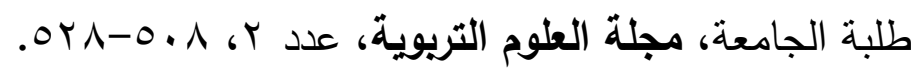

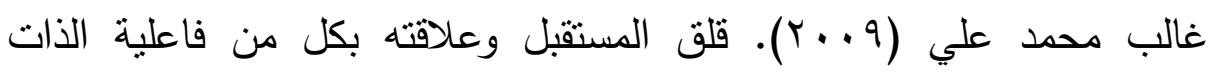
ومستوي الطموح لدي عينة من طلاب جامعة الطائف، رسالة دكتوراه، كلية

$$
\text { التربية، جامعة ام القري. }
$$

كاميليا عبدالفتاح (ع 9 (1). مستوي الطموح والثخصية، بيروت: دار النهضة العربية للطباعة والنشر والتوزيع. كاميليا عبدالفتاح ( •99 (1). دراسات سيكولوجية في مستوي الطموح، القاهرة: دار نهضة مصر للطباعة والنشر •

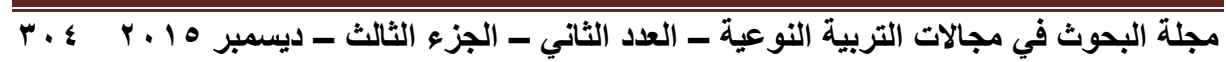


تنمية مهارات تصيميم القصة الرقمية باستخدام الكتاب الإلكتروني وعلاقتها بمستوي طموح معلمي المرحلة الابتدائية

كرامي بدوي أبو مغنم (r • (Y). فاعلية القصص الرقمية التشاركية في تدريس

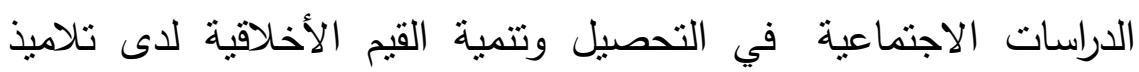
المرحلة الإعدادية، مجلة الثقافة والتنمية، العدد (V0)، السنة الرابعة التهبه

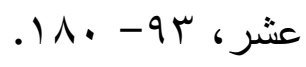

كمال دسوقي (ع/911). علم النفس ودراسة التوافق، بيروت: دار النهضة العربية للطباعة والنشر والتوزيع. حان.

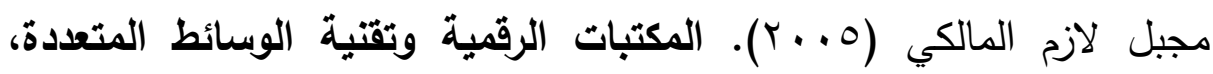
عمان: دار الوراق للنشر والتوزيع.

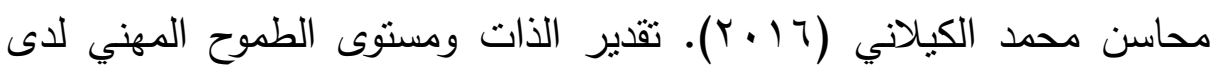
الطلاب الصم ذوى مستويات مختلفة من الإنجاز الأكاديمي، رسالة ماجستير، كلية التربية، جامعة الزقازيق.

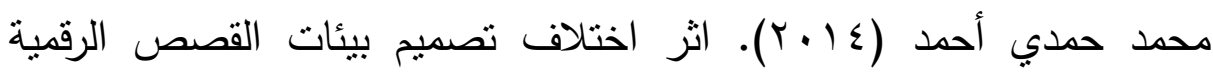
التعليمية (ثنائية/ثلاثثة) الأبعاد لتتمية مهارات التفكير البصري والتحصيل

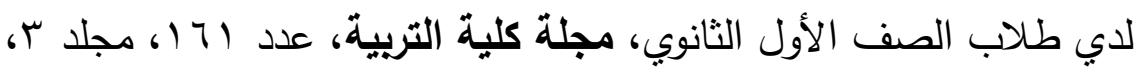

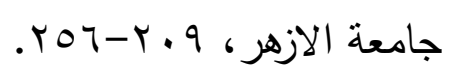

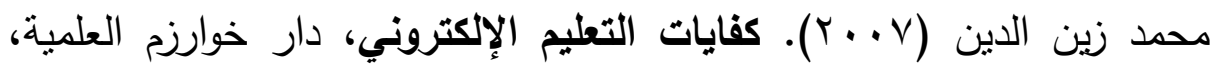
جدة.

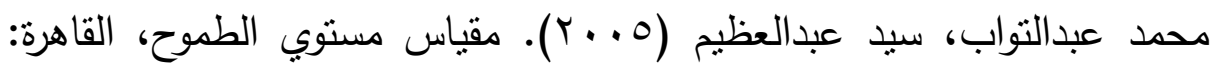
مكتبة الانجلو المصرية.

محمد عبدالرؤوف الثيخ (997 (1). ادب الأطفال ويناء الشخصية، طץ، دبي: دار القلم.

محمد عبدالقوي أحمد (ع (Y). أثز استخدام كتاب إلكتروني قائم علي حل المشكلات في تدريس العلوم علي تتمية بعض مهارات التفكير لدي تلاميذ

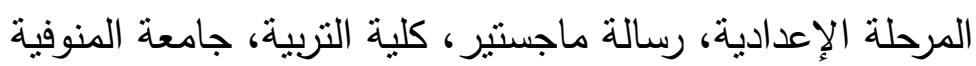

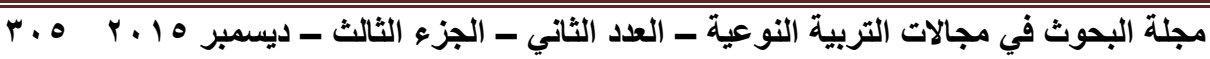


تنمية مهارات تصيميم القصة الرقمية باستخدام الكتاب الإلكتروني وعلاقتها بمستوي طموح معلمي المرحلة الابتدائية

محمد فتحي، أبوالسعود ابراهيم (V . . . ( النشر الإلكتروني ومصادر المعلومات الإلكترونية، القاهرة: دار الثقافة العلمية. محمد محمد السعيد (1/. (1). الكتاب الإلكتروني المفهوم والمزايا، مجلة المعلوماتية، العدد الرابع والثلاثون، بح-7 7.

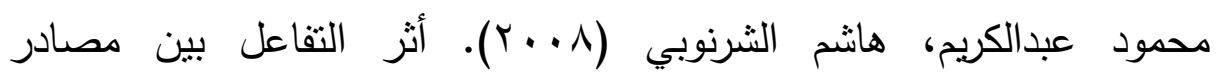
المعلومات الإككترونية والسعة العقلية في التحصبل ومهارات التعلم الذاتي لاى طلاب تكنولوجيا التعليم بكلية التربية، مجلة كلية التربية، عدد VT)

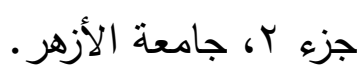

محمود محمد أحمد، سبد شعبان عبدالعليم (rا • ب). فاعلية اختلاف بعض انماط تصميم الكتاب الإكتروني التفاعلي في تتمية مهارات تصميم المقررات الإلكترونية لدي معلمي الحاسب الالي، دراسات عربية في التربية

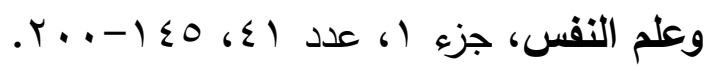
سمية رياض عيسوي (با • r). فعالية تصميم الكتاب الإلكتروني في التحصيل ومهارات التعليم الذاتي لدى تلامبذ المرحلة الاعدادية في مقرر التربية الفنية ، رسالة دكتوراه، كلية التربية الفنية، جامعة حلوان. مخلد حمزة حسين (ع ( . (Y). فاعلية الكتاب الإكتروني في التحصبل وكفاءة تعلم الجغرافيا لدى طلاب المرحلة الثانوبة بالعراق واتجاهاتهم نحوه، رسالة ماجستير ، كلية التربية، جامعة حلوان. مدحت عبدالحمبد عبداللطيف (999 1). الصحة النفسية والتوافق الدراسي، الاسكندربة: دار المعرفة.

مشاعل محمد سليمان (ب ( • (Y). فاعلية كتاب الكتروني مقترح في تتمية بعض مهارات البرمجة بلغة الفيجوال بيسك في مقرر الحاسب الالي لدي طالبات الصف الثاني الثانوي، رسالة ماجستير، برنامج الدراسات العليا التربوبة، جامعة الملك عبدالعزيز . 
تنمية مهارات تصيميم القصة الرقمية باستخدام الكتاب الإلكتروني وعلاقتها بمستوي طموح معلمي المرحلة الابتدائية

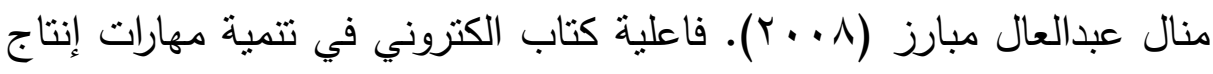
عروض الوسائط المتعددة لمعلمًات الروضة، مؤتمر تكنولوجيا التربية وتعليم الطفل العربي، معهد الدراسات التربوية بجامعة القاهرة والجمعية

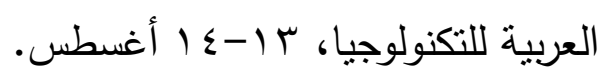
مها إبراهيم عبداله (10 (10). أثز تصميم الكتاب الإلكتروني في الجوانب والمهارية

المعرفية

لاى ذوى صعوبات التعلم للحلقة الإعدادية فاعلية، رسالة ماجستير، معهد البحوث والدراسات التربوية، جامعة القاهرة.

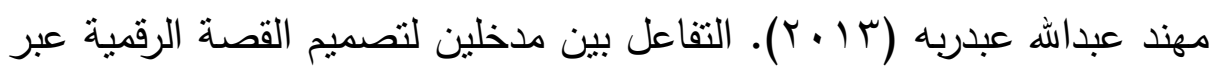
الويب مع الاسلوب المعرفي وأثزه علي اكتساب المعرفة وتتمية التقكير الابداعي لدي طلية تكنولوجيا التعليم، رسالة دكتوراه، كلية البنات، جامعة ولهرة

عين شمس.

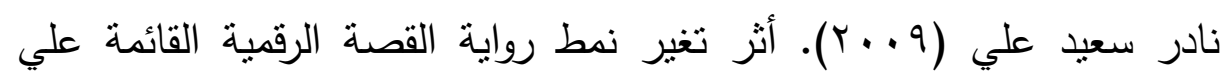

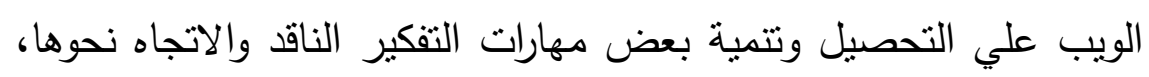

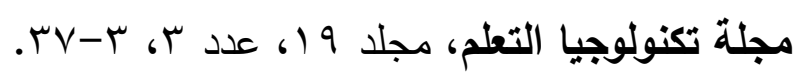

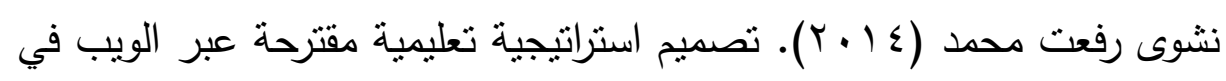

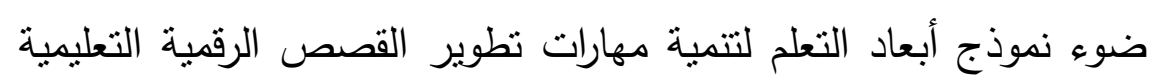

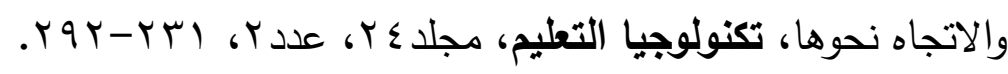
نظيمة أحمد سرحان (1991). العلاقة بين مستوي الطموح والرضا المهني للأخصائيين الاجتماعيين، مجلة علم النفس، العدد الثامن والعشرون، لونه

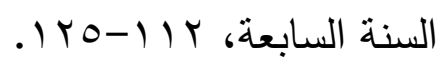

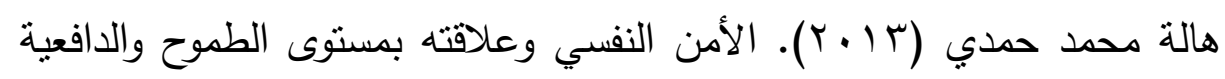
للإنجاز لطلاب المرحلة الثانوية العامة، رسالة ماجستير، كلية التربية، جامعة حلوان.

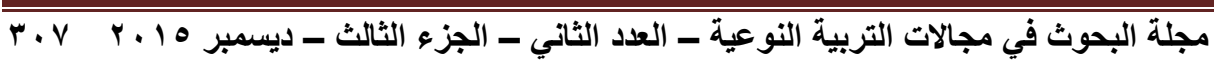


تنمية مهارات تصميم القصة الرقمية باستخدام الكتاب الإلكتروني وعلاقها بمستوي طموح معلمي المرحلة الابتدائية

هديل محمد عبداله (10 ( ب). فاعلية استخدام القصص الإلكترونية في تتمية بعض المهارات اللغوبة لاي طفل الروضة، رسالة ماجستير، كلية التربية،

$$
\text { جامعة ام القري، السعودية. }
$$

هناء محمد علي (ع ( ب). أثر استخدام الكتاب الإلكتروني على التحصيل

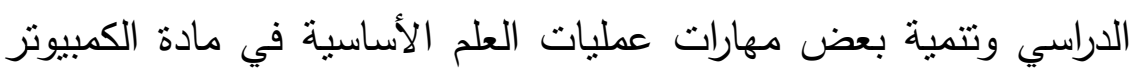
وتكنولوجيا المعلومات لدى تلاميذ المرحلة الإعدادية رسالة ماجستير، كلية التربية النوعية، جامعة بنها.

هويدا محمد الحسيني (ع ا.ب). تقويم الكتاب الإكتروني في اللغة العربية للصف الثالث الابتدائي في ضوء معايير الجودة، مجلة دراسات عربية في

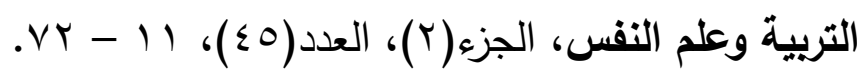

وليد جابر أحمد (0 . . ب). طرق التدريس العامة تخطيطها وتطبيقاتها التريوية،

$$
\text { ثانيا ـ المراجع الاجنبية: دار الفكر. }
$$

Dogan, B; Robin, B (2008). Implementation of Digital Storytelling in the Classroom by Teachers Trained in a Digital Storytelling Workshop, Paper presented at the Society for Information Technology \& Teacher Education International Conference, Association for the Advancement of Computing in Education (AACE), Mar 03, Las Vegas, Nevada, USA, 902-907

Fenwick, Jr et al (2013). Developing a highly interactive eBook for CS instruction, In Proceeding of the 44th ACM Technical Symposium on Computer Science Education, Denver, Colorado, USA - March 06-09, 135-140.

Frazel M (2010). Digital Storytelling Guide for Educators, Retrieved from http://www.iste.org/images/excerpts/digsto-excerpt.pdf.

Gable S A (2011). Storytelling in eLearning: The why and how, retrieved from http://elearnmag.acm.org/featured.cfm?aid=2038641

Heo, M (2011). Improving Technology Competency and Disposition of Beginning Pre-Service Teachers with Digital Storytelling, Journal of Educational Multimedia and Hypermedia, 20(1), 


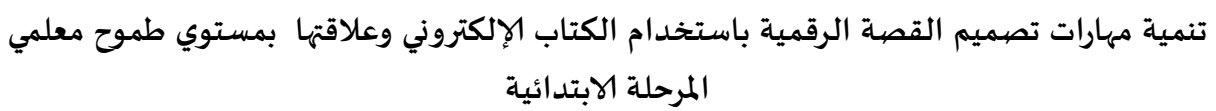

61- 81 .

Hung, C; Hwang, G; Huang, I (2012). A Project- Based Digital Storytelling Approach for Improving Students' Learning Motivation, Problem- Solving Competence and Learning Achievement, Journal of Educational Technology \& Society, 15(4), 368- 379.

Kieler, L (2010). A Reflection: Trails in Using Digital Storytelling Effectively with the Gifted, Gifted Child Today Journal, 33(3), 48- 52.

Kissinger, J S (2013). The Social \& Mobile Learning Experiences of Students Using Mobile E-Books, Journal of Asynchronous Learning Networks, 17(1), 155-170.

Lambert J (2010). Digital Storytelling, Cookbook, retrieved from https://wrd.as.uky.edu/sites/default/files/cookbook.pdf

Lambert J (2013). Digital Storytelling: Capturing Lives, Creating Community, 4th edition, Routledge, New York, Retrieved from https://www.scribd.com/document/289583720/Joe-Lambert-

Digital-Storytelling-Capturing-Live-BookZZ-org-pdf.

McLellan, H (2006). Digital Storytelling in Higher Education .Journal of Computing in Higher Education, 19(1), 65-79.

Ohler, J (2006). The World of Digital storytelling. Educational Leadership, 63(4), 44-47.

Richard M, R; Edward L, D (2008). Self-determination theory and the role of basic psychological needs in personality and the organization of behavior, retrieved from https://www.researchgate.net/publication/232502441.

Thang, S M et al (2014). Technology Integration in the Form of Digital Storytelling: Mapping the Concerns of Four Malaysian ESL Instructors, Computer Assisted Language Learning, 27(4), 311329.

Yang, Y-T; Wu, W-C (2012). Digital Storytelling for Enhancing Student Academic Achievement, Critical Thinking and Learning Motivation: A Year- Long Experimental Study, Journal of Computers \& Education, 59(2), 339-352.

Web site:

Apple (2012). retrieved from

https://www.apple.com/newsroom/2012/01/19Apple-Reinvents-

Textbooks-with-iBooks-2-for-iPad/

https://iphoneislam.com/2012/01/apples-education-announcementsummary/17010

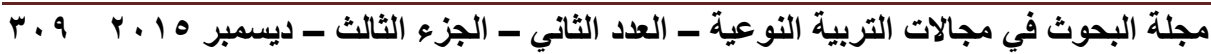

